UDK 902

ISSN 1330-0644

VOL 36/2019.

ZAGREB, 2019.

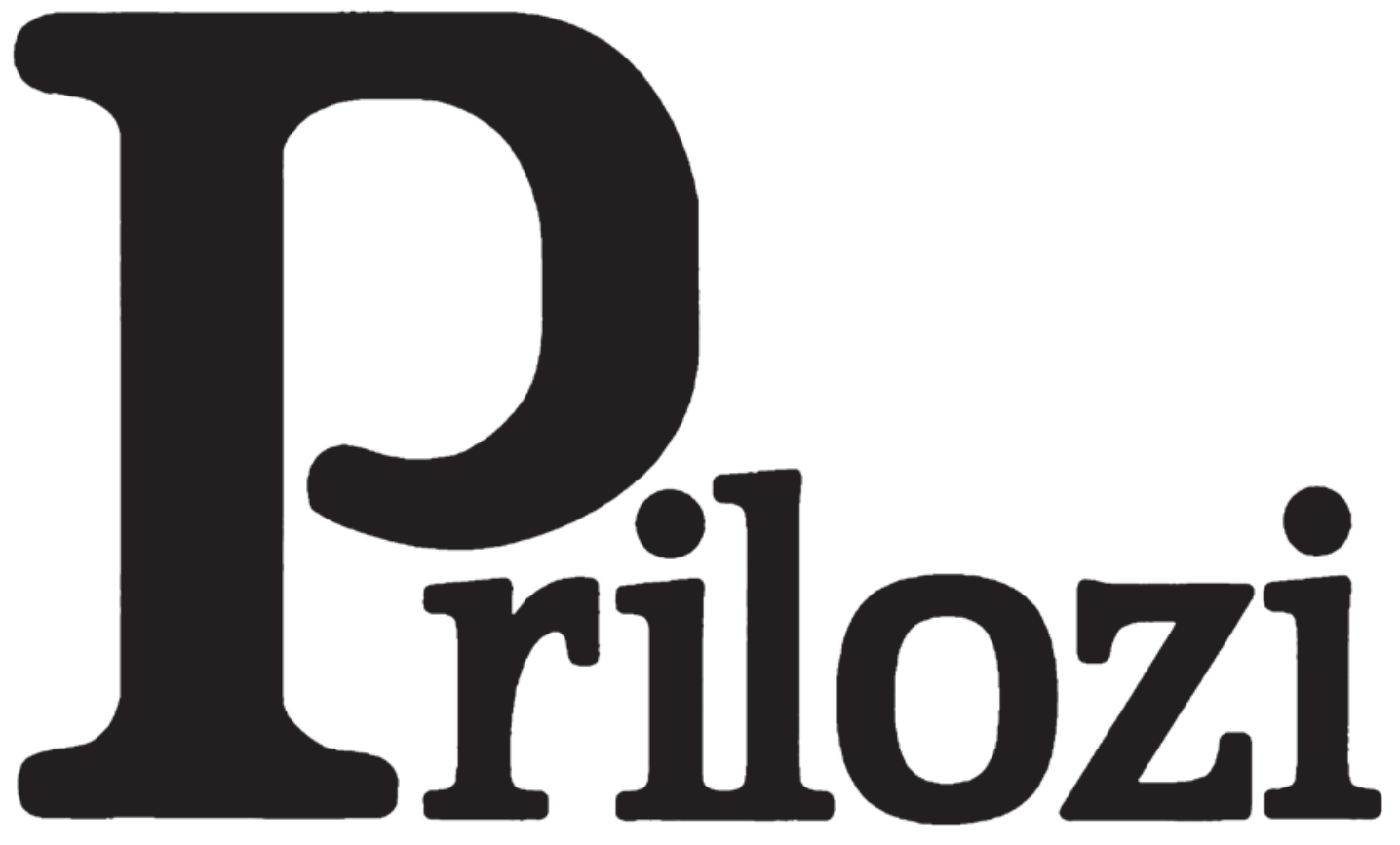

Instituta za arheologiju u Zagrebu 
Pril. Inst. arheol. Zagrebu, 36/2019

Str./Pages 1-196, Zagreb, 2019.
Izdavač/Publisher

INSTITUT ZA ARHEOLOGIJU

INSTITUTE OF ARCHAEOLOGY

Adresa uredništva/Address of the editor's office

Institut za arheologiju/Institute of archaeology

HR-10000 Zagreb, Ulica Ljudevita Gaja 32

Hrvatska/Croatia

Telefon/Phone ++385/(0)1 6150250

Fax $++385(0) 16055806$

e-mail: urednistvo.prilozi@iarh.hr

http://www.iarh.hr

Glavni i odgovorni urednik/Editor in chief

Marko DIZDAR

Uredništvo/Editorial board

Marko DIZDAR, Snježana KARAVANIĆ, Viktória KISS (Budapest, HUN) (prapovijest/Prehistory), Goranka LIPOVAC VRKLJAN (antika/Antiquities), Tajana SEKELJ IVANČAN, Katarina Katja PREDOVNIK (Ljubljana, SLO), Natascha MEHLER (Wien, AUT), Juraj BELAJ, Tatjana TKALČEC (srednji vijek i novi vijek/Middle Ages and Modern era), Predrag NOVAKOVIĆ (Ljubljana, SLO) (metodologija/Methodology)

Izdavački savjet/Editorial advisory board

Dunja GLOGOVIĆ (Zagreb), Ivor KARAVANIĆ (Zagreb), Laszlo KÓVACS (Budapest, HUN),

Kornelija MINICHREITER (Zagreb), Mladen RADIĆ (Osijek), Aleksandar RUTTKAY (Nitra, SK), Ivančica SCHRUNK (Minneapolis, USA), Željko TOMIČIĆ (Zagreb), Ante UGLEŠIĆ (Zadar)

Prijevod na engleski/English translation

Ivan ARBANAS, Marko BANDA, Domagoj BUŽANIĆ, Mario CARIĆ, Marko MARAS, Andreja MAVER, Goran TOMAC, Mirna VUKOV

Lektura/Language editor

Ivana MAJER (hrvatski jezik/Croatian)

Marko MARAS (engleski jezik/English)

Korektura/Proofreads

Katarina BOTIĆ

Marko DIZDAR

Grafičko oblikovanje/Graphic design

Roko BOLANČA

Računalni slog/Layout

Hrvoje JAMBREK

Tisak/Printed by

Tiskara Zelina d.d., Sv. I. Zelina

Naklada/Issued

400 primjeraka/400 copies

Prilozi Instituta za arheologiju u Zagrebu uključeni su u sljedeće indekse/ Prilozi Instituta za arheologiju u Zagrebu are included in following indices:

DYABOLA - Sachkatalog der Bibliothek - Römisch-Germanische Kommission des Deutschen Archaeologischen Instituts, Frankfurt a. Main

Clarivate Analytics services - Emerging Sources Citation Index

CNRS/INIST - Centre National de la Recherche Scientifi que/L'Institut de I'Information Scientifi que et Technique, Vandoeuvre-lès-Nancy

EBSCO - Information servises, Ipswich

ERIH - European Reference Index for the Humanities, European Science Fundation, Strasbourg SciVerse Scopus - Elsevier, Amsterdam 
Sadržaj

\section{Izvorni znanstveni radovi}

MARKO BANDA

IVOR KARAVANIĆ

Mustjerska industrija špilje Veternice

41

\author{
RAJNA ŠOŠIĆ KLINDŽIĆ \\ HRVOJE KALAFATIĆ \\ BARTUL ŠILJEG \\ TOMISLAV HRŠAK
}

Krugovi i keramika kroz stoljeća: značajke naselja

sopotske kulture

\section{DARIA LOŽNJAK DIZDAR}

Status žena u podunavskim zajednicama u starijem željeznom dobu -

Primjer groba 1 iz Sotina

121

MIRJANA SANADER

MIRNA VUKOV

DOMAGOJ BUŽANIĆ

Pax Romana između Burna i Tilurija.

Krajolik sukoba?

135 MITJA GUŠTIN

The belt-buckle with Bacchus from "Romuliana"

143 MAJA BAUSOVAC

Kasnorimski lonci za pohranu s T-oblikom ruba iz Rifnika kod Celja

\section{Contents}

\section{Original scientific papers}

\author{
MARKO BANDA \\ IVOR KARAVANIĆ \\ The Mousterian industry of Veternica Cave
}

\author{
RAJNA ŠOŠIĆ KLINDŽIĆ \\ HRVOJE KALAFATIĆ \\ BARTUL ŠILJEG \\ TOMISLAV HRŠAK \\ Circles and ceramics through the centuries: \\ Characteristics of Neolithic Sopot culture settlements
}

\section{DARIA LOŽNJAK DIZDAR}

Status of women in the Danube Basin communities in the Early Iron Age-

Example of grave 1 from Sotin

\section{MIRJANA SANADER \\ MIRNA VUKOV \\ DOMAGOJ BUŽANIĆ}

Pax Romana between Burnum and Tilurium.

Landscape of conflicts?

\section{MITJA GUŠTIN}

Pojasna kopča s Bakhom iz „Romuliane”

MAJA BAUSOVAC

Late Roman storage jars with a T-shaped rim from Rifnik near Celje, Slovenia 
BRINA ZAGORC

DARIA LOŽNJAK DIZDAR

ANITA RAPAN PAPEŠA

ANDREA RIMPF

MISLAV ČAVKA

IVOR JANKOVIĆ

MARIO NOVAK

Bioarheologija kasnoavarske populacije iz nalazišta

Šarengrad - Klopare: preliminarni rezultati

\section{Prikazi}

KREŠIMIR MIJIĆ

Tomislav Fabijanić, Miroslav Glavičić, Mirko Rašić, Kulturno povijesna baština općine Ljubuški: Zbornik radova

KREŠIMIR MIJIĆ

Irena Radić Rossi - Giulia Boetto (ur.), Pakoštane - Veli Školj: Kasnoantički brodolom u geološkogeografskom i kulturno-povijesnom kontekstu
MARIO CARIĆ

BRINA ZAGORC

DARIA LOŽNJAK DIZDAR

ANITA RAPAN PAPEŠA

ANDREA RIMPF

MISLAV ČAVKA

IVOR JANKOVIĆ

MARIO NOVAK

Bioarchaeology of the Late Avar population from Šarengrad - Klopare: preliminary results

\section{Book reviews}

\section{KREŠIMIR MIJIĆ}

Tomislav Fabijanić, Miroslav Glavičić, Mirko Rašić, The Culture-historical Heritage of the municipality of Ljubuški: The Collection of Papers

\section{KREŠIMIR MIJIĆ}

Irena Radić Rossi - Giulia Boetto (eds.), Pakoštane - Veli Školj: The Late Roman Shipwreck in Its Geological-geographic and Cultural-historical Context 


\title{
Status žena u podunavskim zajednicama u starijem željeznom dobu -
}

\section{Primjer groba 1 iz Sotina}

\section{Status of women in the Danube Basin communities in the Early Iron Age -}

\section{Example of grave 1 from Sotin}

Izvorni znanstveni rad

Prapovijesna arheologija

Original scientific paper

Prehistoric archaeology

\author{
DARIA LOŽNJAK DIZDAR \\ Institut za arheologiju \\ Ulica Ljudevita Gaja 32 \\ HR-10000 Zagreb \\ dldizdar@iarh.hr
}

UDK/UDC 305-055.2:[903.5(497.5 Sotin)"638"

Primljeno/Received: 26. 01. 2019.

Prihvaćeno/Accepted: 29. 07. 2019.

\begin{abstract}
Starije željezno doba na prostoru istočne Slavonije, zapadne Bačke i zapadnoga Srijema naseljavale su zajednice koje se povezuju s materijalnom kulturom grupe Dalj. Kontinuitet u naseljavanju i pokopavanju na istim položajima može se pratiti od kasnoga brončanog doba. U novim istraživanjima groblja iz kasnoga brončanog i starijega željeznog doba u Sotinu pronađeno je 119 grobova. Radi se o paljevinskim grobovima, pri čemu su spaljeni ostaci pokojnika s ostacima nošnje i osobnim predmetima u većini grobova bili položeni u žare te poklopljeni zdjelom u funkciji poklopca. U grobovima starijega željeznog doba bili su položeni i keramički servisi sastavljeni od lonaca, šalica, kantharosa i zdjela koji su sadržavali piće i jelo - popudbinu u pogrebnome ritualu. Interdisciplinarne analize konteksta, nalaza i uzoraka omogućavaju detaljnije interpretacije pogrebnih običaja, identiteta i statusa pokojnika kroz analizu pojedinačnih grobova. Siguran kontekst u kojem su povezani keramički nalazi i nakit omogućavaju i detaljnije datacije inventara unutar starijega željeznog doba na prostoru Podunavlja, sagledanoga u mreži komunikacija i utjecaja vidljivih na predmetima i u pogrebnim običajima.
\end{abstract}

Ključne riječi: Sotin, Podunavlje, starije željezno doba, daljska grupa, groblja, ženski grobovi, keramika, fibula

Eastern Slavonia, western Bačka, and western Syrmia in the Early Iron Age were inhabited by communities associated with the material culture of the Dalj group. The continuity of life and burials on the same sites can be followed from the Late Bronze Age. Recent excavations at Late Bronze Age and Early Iron Age cemeteries in Sotin have identified 119 graves. These are cremation graves; in most of them, the cremated remains of the dead and the remains of costume and personal items were placed in urns and covered with a bowl serving as lid. The Early Iron Age graves included ceramic sets of pots, cups, kantharoi, and bowls, containing food and drinks as departing gifts within the funerary rite. Interdisciplinary analyses of contexts, finds, and samples, have led to more detailed interpretations of funerary rites, identities, and the status of the dead, by analysing specific graves. The definite context linking the pottery finds and the jewellery has resulted from the detailed dating of the inventory in the Danube Basin from the Early Iron Age, considered within the network of communications and influences that can be seen from the objects and funerary rites.

Key words: Sotin, Danube Basin, Early Iron Age, Dalj group, cemeteries, women's graves, pottery, fibula

\section{UVOD}

Jugozapadni dio srednjega Podunavlja - današnji prostori jugoistočnoga dijela zapadne Mađarske, istočne Slavonije i zapadne Bačke - tijekom starijega željeznog doba naseljavale su zajednice čija je materijalna kultura, prema keramičkom inventaru i pogrebnim običajima, označena

\section{INTRODUCTION}

In the Early Iron Age, the south-west area of the middle Danube - what today is the south-east of western Hungary, eastern Slavonia, and western Bačka - was inhabited by communities that had a material culture with pottery inventory and funerary rites identified as the Dalj group (Childe 
kao daljska grupa (Childe 1929; Grbić 1939; Vinski-Gasparini 1983; Vasić 1987; Šimić 2004) ili južnopanonskom grupom kasnog brončanog i starijeg željeznog doba (Metzner-Nebelsick 2002; 2017). Istočni susjedi bile su im zajednice bosutske grupe koje su naseljavale prostore Srijema, južne Bačke, južnoga Banata i sjeverne Srbije (Tasić 1971; Vasić 1987; Ložnjak Dizdar 2004). Razvoj daljske i bosutske grupe može se pratiti gotovo istovremeno od 11. do početka 6. st. pr. Kr. (Tasić 1994: 12; Metzner-Nebelsick 2002: 179; Vasić 2008: 353; Dizdar u tisku).

\section{POVIJEST ISTRAŽIVANJA}

Podaci o zajednicama daljske grupe poznati su većinom iz groblja koja su najvećim dijelom istraživana od početka 20. stoljeća kada je iskopavano eponimno groblje na položaju Busija u Dalju (Hoffiller 1938; Mihelić 2009), zatim preko sustavnih istraživanja Lijeve Bare u Vukovaru 50-tih godina 20. stoljeća (Vinski 1959; Demo 2009), višegodišnjih istraživanja u Doroslovu (Trajković 2008), pa sve do novijih istraživanja u Sotinu (Ložnjak Dizdar et al. 2009; Hutinec, Ložnjak Dizdar 2010) i Batini (Bojčić et al. 2011; 2018; Dizdar et al. 2019).

Definiranje pojma daljske grupe za širi repertoar kasnobrončanodobne keramike koja se pojavljuje na prostoru južnoga dijela srednjeg Podunavlja (Childe 1929: 407-409; Grbić 1939: 59) kao i kataloške objave keramičke građe (Hoffiller 1938), stvorili su polazišnu točku za daljnje proučavanje podunavskih zajednica kasnoga brončanog i starijega željeznog doba. Periodizacija daljske grupe načinjena je prema rijetkim metalnim nalazima u dotad istraženim grobovima, a u okviru kulturno-povijesne interpretacije od strane K. Vinski-Gasparini (1973: 158-164, T. 114-125; 1978 : 135-138; 1983: 606-609). Ona je naglasila nemogućnost daljnje razrade starijih faza daljske grupe uslijed oskudnih metalnih priloga u grobovima (Vinski-Gasparini 1983: 606). N. Tasić predstavio je preliminarne mogućnosti periodizacije prema tipologiji keramike i pojavi stranih utjecaja na najvećem istraženom groblju u Doroslovu (Tasić 1994: 9-10). Prikupljanjem gotovo čitavoga dotad dostupnog korpusa nalaza iz različitih europskih muzeja s prostora daljske grupe, C. Metzner-Nebelsick definirala je horizonte materijalne kulture na temelju najbrojnijih keramičkih nalaza, što je istaknula i u njihovu nazivu (Keramik-Horizont) (MetznerNebelsick 1996: 285-286; 2002: 167-179, Abb. 72-78). Podjela na osnovi tipo-kronološke analize keramičkih nalaza, u kombinaciji s grobnim cjelinama s metalnim nalazima, omogućili su detaljniju periodizaciju unutar daljske grupe. R. Vasić je u kronološkom i kulturološkom određenju materijalne kulture iz Doroslova predstavio kronologiju prema kombinacijama keramičkih i metalnih predmeta u grobnim cjelinama uklopivši ih u širu geografsku mrežu rasprostranjenosti (Vasić 2008: 346-354).

Arheološkim istraživanjima groblja na Lijevoj Bari u Vukovaru 50-tih godina 20. stoljeća (Vinski 1959) te istraživanjima groblja u Doroslovu (Trajković 2008) prikupljeni su detaljniji podaci za daljnje razmatranje pogrebnih običaja, a što je K. Vinski Gasparini (1983: 609-610) istaknula na pri-
1929; Grbić 1939; Vinski-Gasparini 1983; Vasić 1987; Šimić 2004) or the Late Bronze and Early Iron Age South Pannonian group (Metzner-Nebelsick 2002; 2017). Their eastern neighbours were the Bosut group communities that inhabited the territories of Syrmia, southern Bačka, southern Banat, and northern Serbia (Tasić 1971; Vasić 1987; Ložnjak Dizdar 2004). The development of the Dalj and Bosut groups can be followed almost simultaneously from the $11^{\text {th }}$ to the beginning of the $6^{\text {th }}$ cent. BC (Tasic 1994: 12; MetznerNebelsick 2002: 179; Vasić 2008: 353; Dizdar in print).

\section{HISTORY OF RESEARCH}

The data on the Dalj group communities are mostly known from the cemeteries which were explored for the most part in the beginning of the $20^{\text {th }}$ century, when the eponymous cemetery at the site of Busija in Dalj was excavated (Hoffiller 1938; Mihelić 2009), then in the 1950s, when Lijeva Bara in Vukovar was systematically excavated (Vinski 1959; Demo 2009), then for several years in Doroslovo (Trajković 2008), up to the recent excavations in Sotin (Ložnjak Dizdar et al. 2009; Hutinec, Ložnjak Dizdar 2010) and Batina (Bojčić et al. 2011; 2018; Dizdar et al. 2019).

The defining of the notion of the Dalj group for the wide range of Late Bronze Age pottery appearing in the area of the southern part of the middle Danube (Childe 1929: 407-409; Grbić 1939: 59), and the catalogue publication of ceramic material (Hoffiller 1938), set up the point of departure for further research on Late Bronze Age and Early Iron Age Danube communities. The periodization of the Dalj group was done on the basis of the rare metal finds in the explored graves and within the cultural and historic interpretation by K. Vinski-Gasparini (1973: 158-164, PI. 114-125; 1978: 135-138; 1983: 606-609). She pointed out that it was impossible to work out the older phases of the Dalj group any further because of the scarcity of metal goods in the graves (Vinski-Gasparini 1983: 606). N. Tasić presented the preliminary possibilities of periodization on the basis of the ceramic topology and the appearance of foreign influences on the biggest excavated cemetery in Doroslovo (Tasić 1994: 9-10). By collecting almost the entire available corpus of finds from several European museums in the area of the Dalj group, C. Metzner-Nebelsick defined the horizons of the material culture on the basis of the most numerous ceramic finds, which she pointed out in their name (KeramikHorizont) (Metzner-Nebelsick 1996: 285-286; 2002: 167-179, Abb. 72-78). The division based on the typo-chronological analysis of the ceramic finds, combined with the funerary complexes with metal finds, enabled a more detailed periodization within the Dalj group. In his chronological and culturological determination of the material culture from Doroslovo, R. Vasić presented a chronology based on the combinations of ceramic and metal objects in funerary complexes, setting them in a wider geographic distribution network (Vasić 2008: 346-354).

The archaeological excavations of the Lijeva Bara cemetery in Vukovar in the 1950s (Vinski 1959) and the excavations of the Doroslovo cemetery (Trajković 2008) collected more detailed data for a further analysis of funerary customs, as pointed out by K. Vinski Gasparini (1983: 609-610) 
mjeru dva spomenuta sustavno istraživana groblja: Vukovar i Doroslovo. Zaključila je kako u načinu pokopavanja u žarnim grobovima nema nikakve razlike između kasnobrončanodobnih i onih iz vremena starijega željeznog doba, jedino su mlađi grobovi ponekad bogatiji u keramičkim prilozima (Vinski-Gasparini 1983: 609). Grobne jame su različite veličine - ovisno o sadržaju groba koji se ponekad sastojao i od 20 posuda. Grobovi se razlikuju od jednostavnih sa žarom poklopljenom zdjelom, do bogato opremljenih čak s 15 do 20 posuda, ... što bi moglo biti ilustracija razlike društvenog položaja, odnosno staleškog raslojavanja pučanstva (VinskiGasparini 1983: 610).

O načinu pokopavanja zajednica na jugoistočnome panonskom prostoru C. Metzner-Nebelsick zaključuje kako se zamijećene razlike u pogrebnome ritualu reflektiraju i u društveno-kulturnom diferenciranju kao i u specifičnome karakteru pojedinih naselja i pripadajućih groblja. Primjer centralnih naselja u Pécs - Jakabhegyu i Batini uvjetovao je i podizanje tumula, dok su na ostalim naseljima zabilježeni samo ravni grobovi (Metzner-Nebelsick 2002: 190). Struktura priloga u grobovima kasnoga brončanog doba daljske grupe odgovara kulturnim grupama istočnoalpskoga kruga i okolnih područja (Metzner-Nebelsick 2002: 200). Bogati keramički servisi u halštatskim grobovima usko povezuju viši sloj u daljskim zajednicama s Međimurjem i jugoistočnoalpskim prostorom (Nebesick 1994: 357; Metzner-Nebelsick 2002: 201). Na daljskom prostoru pronađeno je tek nekoliko ratničkih grobova te grobova konjanika koji bi mogli ukazati na društveno stratificiranje koje je tipično za istočni halštatski krug (Metzner-Nebelsick 2002: 201). Ranije istraživani grobovi, bez sačuvanoga antropološkog uzorka, mogu se prema prilozima pripisati muškarcima ili ženama. $\mathrm{Na}$ području južne Panonije žene su nosile ukras u kosi, zatim narukvice kao i nanogvice te vjerojatno fibule. Grobovima žena još se vjerojatno mogu pripisati nalazi pršljena te utega za tkalački stan (Metzner-Nebelsick 2002: 201).

Na primjeru groblja u Doroslovu, koje je bilo u upotrebi duže vrijeme, razlike u broju grobnih priloga D. Trajković tumači kao dio vjerovanja i rituala koji se odnose na kult mrtvih, a ne nužno kao ogledalo klasne ili materijalne nejednakosti. Ona drži da je odnos prema mrtvima bio vidljiv ne samo u rasporedu priloga tijekom pokopa, nego i kasnije prema obredima vršenima na grobu - prilozi hrane i pića. Raspored priloga u grobovima prilično je ujednačen, što svjedoči o promišljenome pogrebnom obredu (Trajković 2008: 19).

Dosadašnja istraživanja i analize grobova daljske grupe (Vinski-Gasparini 1973; 1978; 1983; Vasić 1987; MetznerNebesick 1996; 2002; Trajković 2008) bila su fokusirana na materijalnu kulturu od koje je najbrojnija lončarija te analize pogrebnih običaja koje karakterizira paljevinski način pokopavanja većinom u žarama.

Grobovi su jedan od osnovnih kontekstualnih izvora arheoloških informacija. Oni pružaju intencionalne i funkcionalne podatke čije kombinacije daju detaljniji uvid u pogrebne običaje i zrcalnu sliku o pojedincu u zajednici u kojoj je živio (Härke 1993: 142). U funkcionalne podatke se ubraja- using the examples of the two systematically explored cemeteries: Vukovar and Doroslovo. She concluded that the urn burial method was the same for the Late Bronze Age and Early Iron Age graves), but some of the younger graves sometimes contained richer ceramic goods (Vinski-Gasparini 1983: 609). Burial pits have different sizes depending on the contents of the grave, which could have as many as 20 vessels. Graves range from simple ones with an urn covered with a bowl to richly furnished ones, with as many as 15 or 20 vessels, ... which could illustrate a difference in the social status, or the class stratification of the population (Vinski-Gasparini 1983: 610).

Regarding the burial method of the communities of the south-eastern Pannonian region, C. Metzner-Nebelsick concludes that the identified differences in funerary rites are reflected by the socio-cultural differentiation and by the specific character of particular settlements and their cemeteries. The example of central settlements in Pécs - Jakabhegy and Batina led to the raising of tumuli, while other settlements were found to have only flat graves (MetznerNebelsick 2002: 190). The structure of the goods in Late Bronze Age graves of the Dalj group matches the cultural groups of the eastern Alpine sphere and the surrounding regions (Metzner-Nebelsick 2002: 200). The rich ceramic sets in Hallstatt graves create a close connection between the high classes of the Dalj communities and of Međimurje and the south-east Alpine region (Nebesick 1994: 357; Metzner-Nebelsick 2002: 201). The excavations in the Dalj area have found only a few graves of warriors and horsemen which could indicate the social stratification which is typical for the eastern Hallstatt sphere (Metzner-Nebelsick 2002: 201). The graves explored earlier, without a preserved anthropological pattern, can be attributed to men or women on the basis of their goods. In the region of southern Pannonia, women wore hair ornaments, bracelets, anklets, and probably fibulae. Also, women's graves can probably be associated with the finds of spindle-whorls and loom weights (Metzner-Nebelsick 2002: 201).

Taking the example of the Doroslovo cemetery, which was used for a relatively long time, D. Trajković explains the differences in the number of grave goods as a part of the beliefs and rituals related to the cult of the dead, not necessarily as a mirror of class or material inequality. She claims that the attitude towards the dead could be seen not only in the layout of the goods during the burial, but also later, in the rituals performed on the grave - the gifts of food and drinks. The layout of the goods in the graves is quite uniform, indicating a planned funerary rite (Trajković 2008: 19).

Past excavations and analyses of the Dalj group graves (Vinski-Gasparini 1973; 1978; 1983; Vasić 1987; Metzner-Nebesick 1996; 2002; Trajković 2008) focused on the material culture, mostly represented by pottery, and the analyses of funerary rites, characterised by cremation burials, mostly in urns.

Graves are a fundamental contextual source of archaeological information. They provide intentional and functional data, which are combined to provide a more detailed insight into the funerary rites, mirroring the individual within the community where he or she lived (Härke 1993: 
ju spol, dob, razlog smrti, zdravstveno stanje i naslijeđe koje uglavnom nude skeletni ostaci. S druge strane, intencijski podaci su tip pokopa, detalji o grobnoj konstrukciji kao i podaci o grobnim prilozima (Härke 1993: 142-143). Objava groblja u Doroslovu s antropološkim i zooarheološkim istraživanjima (Trajković 2008) te istraživanja groblja u Sotinu (Ložnjak Dizdar et al. 2009; Hutinec, Ložnjak Dizdar 2010; Ložnjak Dizdar et al. 2019) i Batini (Bojčić et al. 2011; 2018; Dizdar et al. 2019), s prikupljenim podacima o grobnim cjelinama, inventaru, antropološkim i zooarheološkim uzorcima te podacima o tragovima procesa u pogrebnome ritualu, pružaju mogućnosti detaljnijih analiza groblja u podunavskim zajednicama starijega željeznog doba. U tumačenju identiteta iz pogrebnih običaja jako je važno znati pravilno interpretirati tragove ritualnih radnji i priloga u grobovima gdje se zajednički tumače arheološki i antropološki podaci u opisu rituala (Gramsch 2010: 143, Tab. 12.1). Dosadašnji podaci opisani u literaturi o pogrebnim običajima i prilozima u grobovima daljske grupe odnosili su se na intencijske podatke iz kojih se može zaključivati o statusu pokojnika. U tumačenju društvenoga statusa u obzir su uzimani izuzetni metalni predmeti kojih u grobovima daljske grupe nema u većem broju te broj keramičkih posuda (Vinski-Gasparini 1983: 610; Metzner-Nebelsick 2002: 179-181). Istraživanjem većega broja grobova u Doroslovu (Trajković 2008: 19), Sotinu (Ložnjak Dizdar et al. 2018) i Batini (Bojčić et al. 2018) te provedbom analiza funkcionalnih podataka iz grobova, otvaraju se mogućnosti za detaljnije interpretacije grobova te analize identiteta i statusa pojedinca u zajednicama starijega željeznog doba.

\section{SOTIN GROB 1}

Institut za arheologiju, u suradnji s Gradskim muzejom Vukovar, istražuje groblje kasnoga brončanog i starijega željeznog doba u Sotinu (sl. 1) u kontinuitetu od 2008. godine (Ložnjak Dizdar et al. 2009; Hutinec, Ložnjak Dizdar 2010; Ložnjak Dizdar et al. 2018). Do 2019. godine ukupno je istraženo 119 grobova daljske grupe koji se mogu datirati od 9. do 7. st. pr. Kr., odnosno od II do kraja Illb stupnja.

Na početku istraživanja, zahvaljujući dr. sc. Mati Ilkiću i arhivskim podacima iz Gradskoga muzeja Vukovar, lociran je položaj na kojem je prof. A. Dorn otkrio i istražio grobove 1980. godine tijekom zaštitnih istraživanja prilikom gradnje pristupne ceste za nogometno igralište. Sonda 1 istražena je sjeverno od današnjega nogometnog igrališta u Sotinu u jesen 2008. godine. Već na početku arheoloških istraživanja pri iskopu sonde 1 otkriven je grob 1. Grob 1 je paljevinski grob u žari u raci gotovo kvadratnoga oblika i zaobljenih uglova dimenzija 1,30 x 1,28 m (sl. 2-3). Zapuna groba uočena je na visini od $111,89 \mathrm{~m}$, dok se dno nalazilo na $111,58 \mathrm{~m}$. Vrh zapune nalazio se na relativnoj dubini $0,29 \mathrm{~m}$ od današnje hodne razine. $U$ zapadni dio grobne rake bio je položen lonac u funkciji žare (1) u kojem su, uz spaljene kosti među kojima su bili dijelovi nošnje u kojima je pokojnica spaljena (brončana fibula (13), željezna igla (14)), još bili položeni
142). Functional data include sex, age, cause of death, state of health, and heritage, which are mostly provided by the skeletal remains. On the other hand, there are intentional data: burial type, details of grave structure, and data on grave goods (Härke 1993: 142-143). The publication of the Doroslovo cemetery with anthropological and zooarchaeological research (Trajković 2008) and research on cemeteries in Sotin (Ložnjak Dizdar et al. 2009; Hutinec, Ložnjak Dizdar 2010; Ložnjak Dizdar et al. 2019) and Batina (Bojčić et al. 2011; 2018; Dizdar et al. 2019), together with the collected data on funerary complexes, inventory, anthropological and zooarchaeological samples, and data on the traces of processes in the funerary rite, offer possibilities for more detailed analyses of the cemeteries of Danube communities in the Early Iron Age. When deducing identities from funerary rites, it is crucial to be able to correctly interpret the traces of ritual activities and goods in the graves, interpreting together the archaeological and anthropological data in rite descriptions (Gramsch 2010: 143, Tab. 12.1). Past data, described in the papers on funerary rites and grave goods of the Dalj group, concerns the intention data that can lead to conclusions about the status of the dead. When interpreting social status, the researchers considered exceptional metal objects, which are rare in the Dalj group graves, and the number of ceramic vessels (Vinski-Gasparini 1983: 610; Metzner-Nebelsick 2002: 179-181). The exploration of the large number of graves in Doroslovo (Trajković 2008: 19), Sotin (Ložnjak Dizdar et al. 2018), and Batina (Bojčić et al. 2018), and the analyses of functional data from the graves, have opened possibilities for more detailed interpretations of the graves and for analyses of identities and statuses of individuals in Early Iron Age communities.

\section{SOTIN GRAVE 1}

The Institute of Archaeology, in cooperation with Vukovar Town Museum, has been continuously exploring the Late Bronze Age and Early Iron Age cemetery in Sotin (Fig. 1) since 2008 (Ložnjak Dizdar et al. 2009; Hutinec, Ložnjak Dizdar 2010; Ložnjak Dizdar et al. 2018). Until 2019, a total of 119 graves of the Dalj group were explored; they can be dated to the period from the $9^{\text {th }}$ to the $7^{\text {th }}$ cent. BC, or from phase II to the end of phase IIIb.

At the beginning, thanks to Dr. Mato llkić and the archive data from Vukovar Town Museum, the researchers identified the location where Prof. A. Dorn discovered and explored graves in 1980, during the rescue excavations in the occasion of the construction of the access road to the football ground. Trench 1 was excavated to the north of today's football ground in Sotin in autumn 2008. Grave 1 was discovered as soon as the archaeological excavations started in trench 1. Grave 1 is a cremation burial in an urn in a pit that is almost a square, measuring $1.30 \times 1.28 \mathrm{~m}$ with rounded corners (Figs. 2-3). The grave fill was recorded at the height of $111.89 \mathrm{~m}$, while the bottom was at $111.58 \mathrm{~m}$. The top of the fill was on the relative depth of $0.29 \mathrm{~m}$ from today's walking level. The western part of the burial pit contained a pot serving as urn (1) which contained not only the cremated bones mixed with parts of the costume of the bu- 


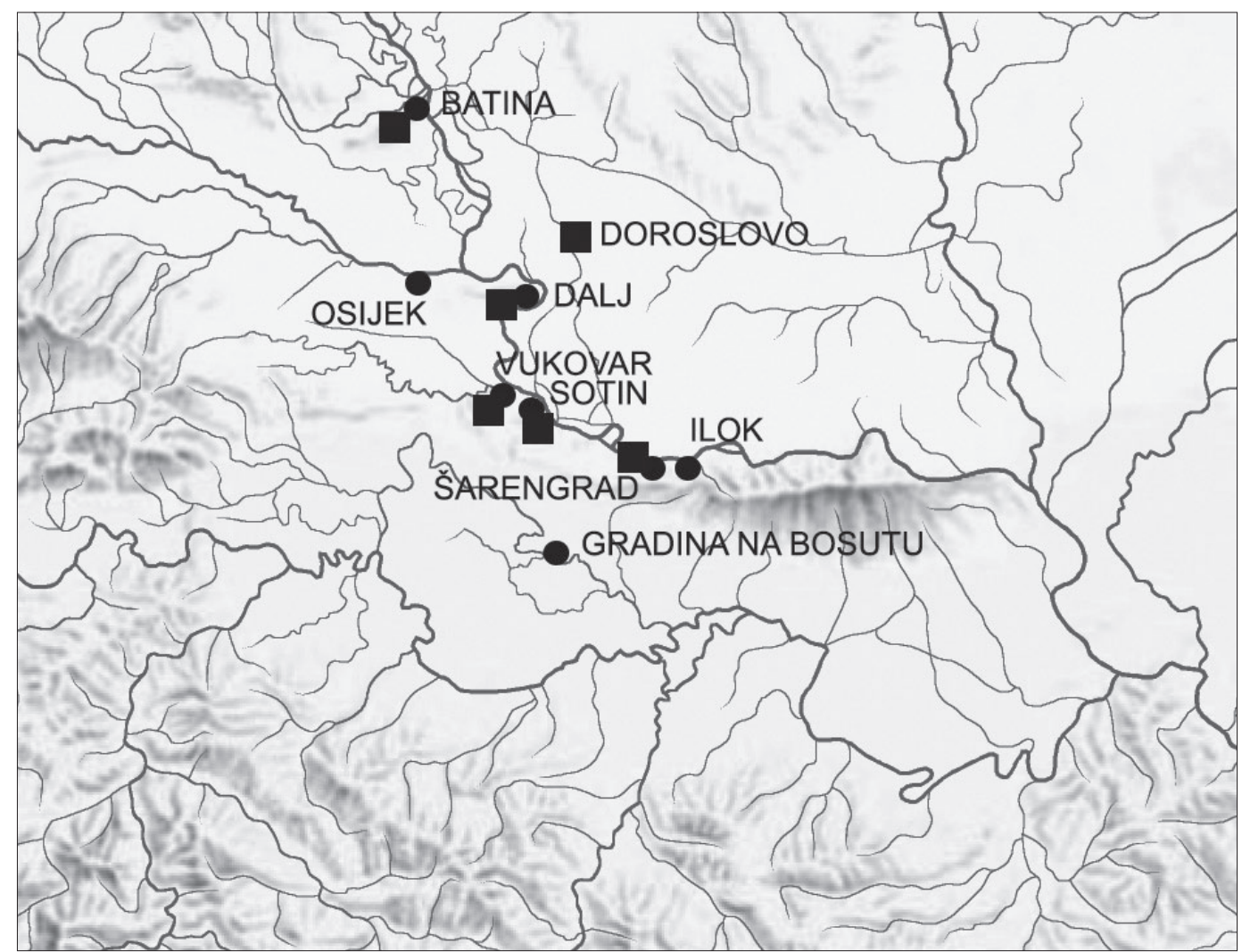

SI. 1 Naselja i groblja starijega željeznog doba u zapadnome Srijemu i zapadnoj Bačkoj (izradila: D. Ložnjak Dizdar)

Fig. 1 Settlements and cemeteries of the Early Iron Age in western Syrmia and western Bačka (made by: D. Ložnjak Dizdar)

mali keramički bikonični pršljen (12), zatim manji lonac (2) te ulomci šalica vjerojatno razbijenih na lomači. Žara je bila pokrivena zdjelom (3) okrenutom s dnom prema gore. Sjeverno od lonca nalazilo se keramičko postolje (11) na kojem je položena plitka zdjela (10). Istočno od zdjele nalazila su se dva lonca (4-5), pri čemu je u jednom (4) pronađena šalica (8), što ukazuje da je on bio recipijent za tekućinu, kao i južno položen lonac (6) u kojem je pronađen kantharos (7). Između njega i dvaju sjevernih lonaca položena je zdjela (9) s kostima mlađe ovce/koze.

Prema antropološkoj analizi, u žari je pronađena veća količina spaljenih kostiju odrasle ženske osobe u dobi od 20-30 godina te maloga djeteta u dobi od 0,16 do 0,22 godine.

Tipo-kronološka analiza nalaza još uvijek je nezaobilazni arheološki alat za što preciznije datiranje predmeta i cjelina, osobito u mlađim razdobljima prapovijesti. Specifičnost inventara grobova u Podunavlju je obilje keramičkih predmeta te mali broj metalnih nalaza koji su odraz paljevinskoga načina pokopavanja, a vjerojatno i odraz nošnje.

U grobu 1 u Sotinu od keramičkih nalaza pronađeni su dva lonca u funkciji žare, zdjela - poklopac žare te tri lonca, dvije zdjele, jedno postolje, kantharos, šalica i pršljen. Od metalnih nalaza zabilježeni su nalazi brončane fibule te željezna igla. Tipovi predmeta otkriveni u grobu daju osnovu ried woman (bronze fibula (13), iron pin (14)), but also a small ceramic biconical spindle-whorl (12), a small pot (2), and fragments of cups that were probably broken on the pyre. The urn was covered with an upside-down bowl (3). North of the pot there was a ceramic stand (11) with a shallow bowl (10). East of the bowl, there were two pots (4-5), one of them (4) containing a cup (8), indicating that it was a recipient of a liquid, and a pot in the south (6) with a kantharos (7) inside it. Between it and the two pots in the north, there was a bowl (9) with the bones of a young sheep/goat.

The anthropological analysis concluded that the urn contained a relatively large quantity of the cremated bones of an adult woman aged between 20 and 30 and a small child aged between 0.16 and 0.22 .

The typo-chronological analysis of finds is still an indispensable archaeological tool for precise dating of objects and complexes, especially from the younger periods of prehistory. A particularity of Danube grave inventories is the wealth of ceramic objects and the scarcity of metal finds, reflecting the cremation burial method and probably the costume too.

The ceramic finds from grave 1 in Sotin included two pots serving as urns, a bowl serving as urn lid, and three pots, two bowls, one stand, a kantharos, a cup, and a spindle-whorl. The metal finds are a bronze fibula and an iron 


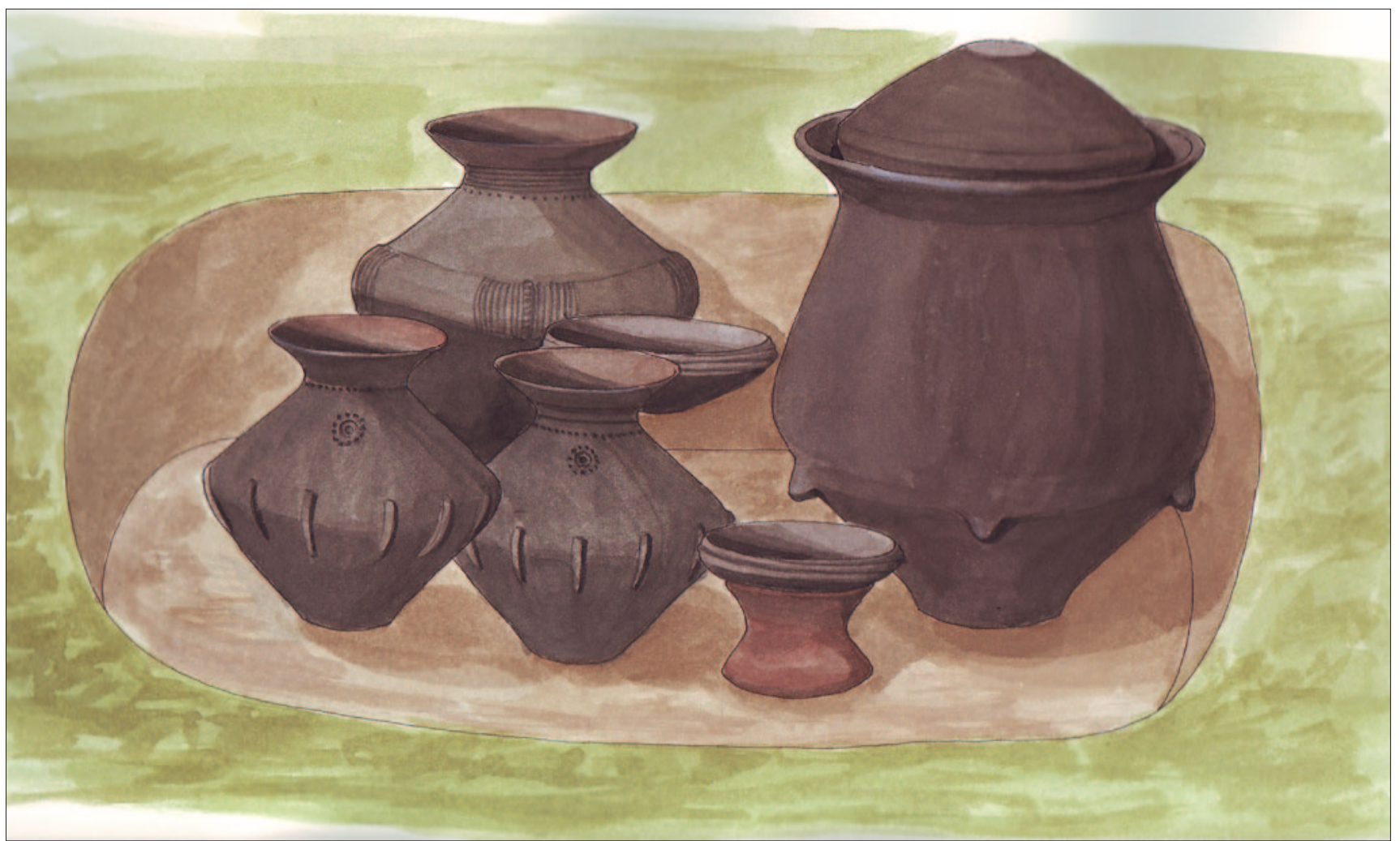

SI. 2 Rekonstrukcija groba 1 u Sotinu (crtež: K. Rončević)

Fig. 2 Reconstruction of grave 1 in Sotin (drawing by: K. Rončević)

za precizniju dataciju groba. S druge strane, položaj pojedinih nalaza u grobu pomaže rekonstruirati scenarij pogrebnih običaja i oproštaja od pokojnika te, prema materijalnim dokazima i tragovima manipulacije grobnim prilozima, u ocrtavanju identiteta i statusa pokojnika u zajednici koja ih je sahranila.

Spaljene kosti pokojnika u grobu 1 bile su položene u veliki bikonični lonac s izvučenim rubom i četiri funkcionalno-dekorativna dodatka u donjem dijelu posude (1). U loncu je pronađen manji lonac zaobljenoga tijela koji je u svome gornjem dijelu ukrašen vodoravnim nizom otisaka prsta između kojih su četiri manja izbočenja u funkciji drški (2). Za oba lonca se, prema kontekstu nalaza i rezultatima antropološke analize spaljenih ostataka, može reći kako su imali funkciju žare.

\section{ŽARE}

\section{LONAC - ŽARA (T. 1: 2)}

Keramika; visina: $51,0 \mathrm{~cm}$; najveća širina: $46,8 \mathrm{~cm}$; promjer oboda: $38,4 \mathrm{~cm}$; promjer dna: $15,0 \mathrm{~cm}$.

Lonac bikoničnoga tijela, izvučenoga ruba i ravnoga dna. Prijelaz tijela u vrat lonca nalazi se $u$ donjem dijelu posude. Na donjem dijelu tijela nalaze se četiri jezičasta funkcionalno-dekorativna dodatka. Vanjska površina je tamnosmeđe, a unutarnja je svjetlosmeđe boje. U loncu su pronađene spaljene kosti, manji lonac (2), brončana fibula (13), željezna igla (14) i mali keramički bikonični pršljen (12).

Institut za arheologiju, PN 1. pin. The types of the objects discovered in the grave provide the basis for more precise dating of the grave. On the other hand, the position of particular finds in the grave helps reconstruct the ceremony of funerary rites and farewell from the dead; also, material evidence and traces of manipulation of grave goods help outline the identity and status of the dead in the community that buried them.

The cremated bones of the dead in grave 1 were laid in a large biconical pot with an everted rim and four functional/ decorative additions in the lower part of the vessel (1). The pot contained a smaller pot with a spherical body, decorated with a horizontal series of fingerprints in the upper part, alternating with four small protrusions serving as handles (2). The context of the find and the results of the anthropological analysis of the cremated remains indicate that both pots served as urns.

\section{URNS}

\section{POT - URN (PI. 1: 2)}

Ceramic; height: $51.0 \mathrm{~cm}$; maximum width: $46.8 \mathrm{~cm}$; rim diameter: $38.4 \mathrm{~cm}$; bottom diameter: $15.0 \mathrm{~cm}$.

A pot with a biconical body, everted rim, and flat bottom. The joint of the body and the neck is in the lower part of the vessel. The lower part of the body has four tanged functional/decorative additions. The outside is dark brown; the inside is light brown. The pot contained cremated bones, a smaller pot (2), a bronze fibula (13), an iron pin (14), and a small ceramic biconical spindle-whorl (12).

Institute of Archaeology, SF 1. 
G 1
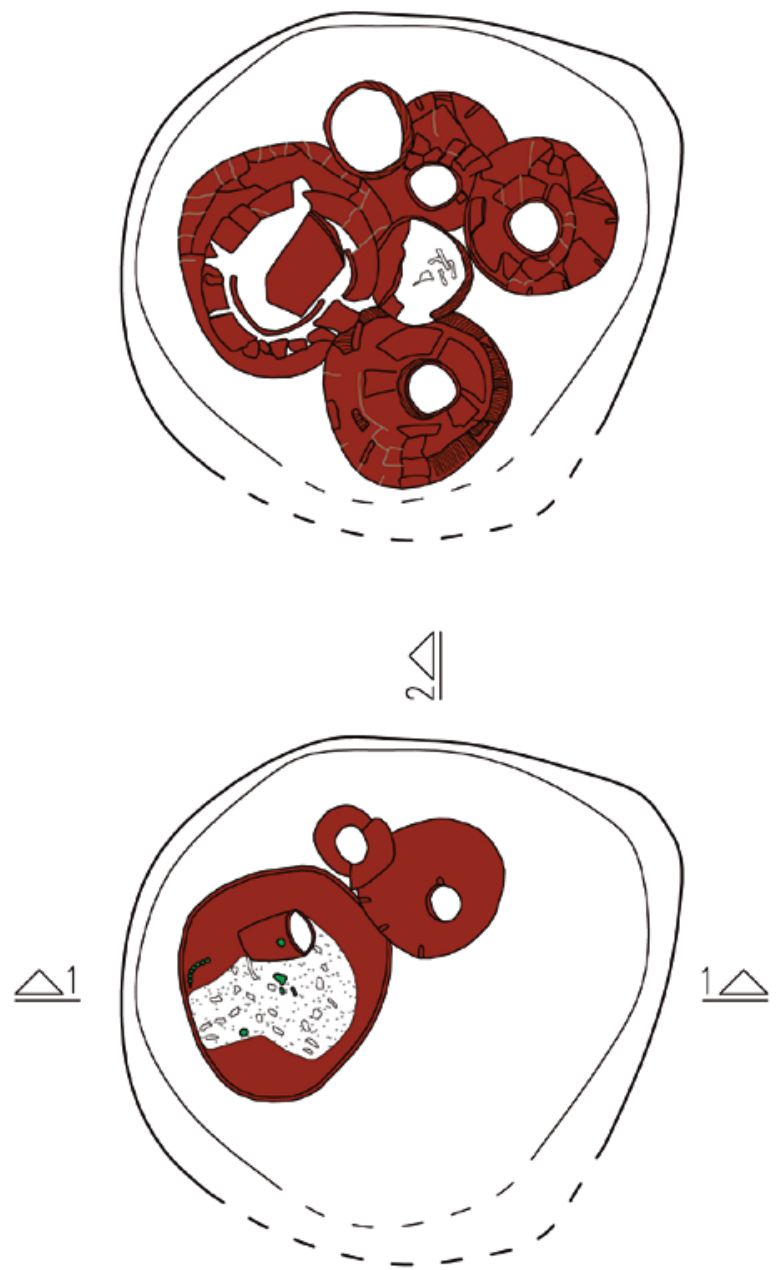

\langle

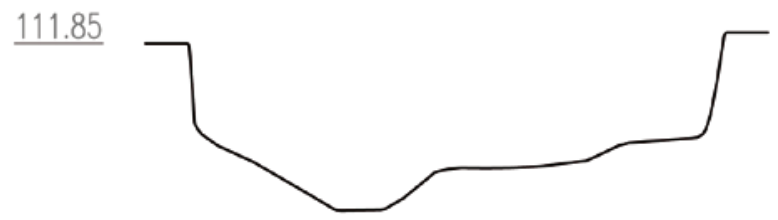

$\underline{111.85}$

$\underline{111.85}$
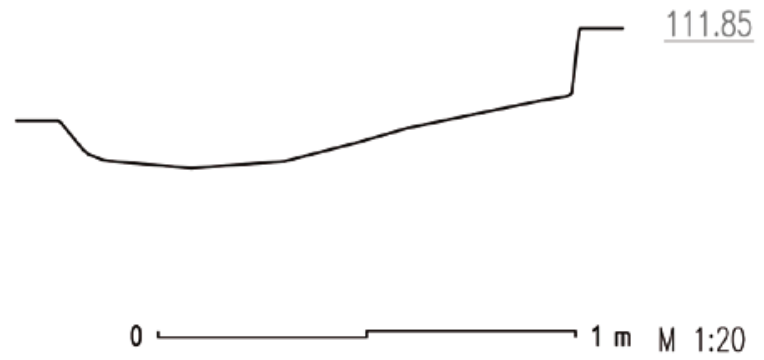

SI. 3 Tlocrt groba 1 (crtež: D. Ložnjak Dizdar; priredio: Arheoplan d.o.o.)

Fig. 3 Ground plan of grave 1 (drawing by: D. Ložnjak Dizdar; layout design: Arheoplan Ltd.) 


\section{LONAC (T. 2: 4)}

Keramika; visina: $12,1 \mathrm{~cm}$; najveća širina: $12,7 \mathrm{~cm}$; promjer oboda: 10,5 cm; promjer dna: $8,1 \mathrm{~cm}$.

Lonac zaobljenoga tijela, ravnoga ruba i ravnoga dna. Na najširem dijelu ukrašen je vodoravnim nizom otisaka prsta između kojih su četiri manja izbočenja u funkciji drški. Vanjska i unutarnja površina su smeđe boje i glatke obrade. Pronađen je u žari PN 1.

Institut za arheologiju, PN 8.

Veća žara (1) pronađena u grobu 1 ima paralele u nalazu bez konteksta iz Vukovara, položaj Lijeva Bara (Metzner-Nebelsick 2002: T. 112: 1) te u nalazima iz Dalja, grob 9, vinograd Panišić 1911 (Hoffiller 1938: PI. 2: 4; Vinski-Gasparini 1973: T. 115: 4; Metzner-Nebelsick 2002: T. 67: 4), zatim u Batini među nalazima izvan konteksta (Metzner-Nebelsick 2002: PI. 2: 1) te u novijim istraživanjima ovoga lokaliteta gdje je slična žara zabilježena u grobu 37 koji je datiran u prijelaz IIIb/IV horizont prema periodizaciji C. Metzner-Nebelsick (Bojčić et al. 2018: 170, 177, T. 2: 3). U grobovima 51, 95, 105 i 117 u Doroslovu pronađeni su oblikom slični lonci (Trajković 2008: grob 51, 1; grob 95, 1; grob 105, 1; grob 117, 2) koji također imaju funkciju žare. Slična žara pronađena je i u Erdutu na položaju Žarkovac (Minichreiter 1985: 26-27, T. XVI: 1). Najbliže usporedbe pronađene su u grobu 1911/9, vinograd Panišić u Dalju te u spomenutome grobu iz Erduta koji su karakteristični za Illb stupanj prema C. Metzner-Nebelsick, na osnovi čega se može zaključiti kako su takvi lonci u funkciji žare u upotrebi u Ha C1b stupnju (Metzner-Nebelsick 2002: 175, Abb. 75: 6).

Manji lonac (2) pronađen u žari ima paralele u Batini, zatim u Dalju, grob 16 vinograd Pavošević 1910 (MetznerNebelsick 2002: PI. 30: 10; 69: 3) te u grobu 130 u Doroslovu (Trajković 2008: grob 130, 7). Dok za Batinu i Dalj nisu poznati bliži konteksti nalaza u grobu, u Doroslovu je taj tip lonca bio priložen u grob kao recipijent za jelo ili piće. Lonac istoga oblika, ali s četiri izdanka na gornjem dijelu tijela, otkriven je u rekonstruiranome kosturnom grobu 1 u Šarengradu (Balen-Letunić 2004: 17, 19-20; T. 6: 2). Manji lonac takvoga oblika s plastičnom trakom ukrašenom kosim urezima pronađen je na podnici kuće 25 na Gradini na Bosutu (Medović, Medović 2011: sl. 96: 11). Prema nalazu u Doroslovu (Trajković 2008: grob 130, 1-22), ovaj oblik lonca može se datirati u IIlb stupanj prema periodizaciji C. Metzner-Nebelsick (2002: 175).

\section{POKLOPAC}

\section{ZDJELA - POKLOPAC (T. 1: 1)}

Keramika; visina: $14,5 \mathrm{~cm}$; najveća širina: $36,0 \mathrm{~cm}$; promjer oboda: 31,5 cm; promjer dna: $8,0 \mathrm{~cm}$.

Zdjela bikoničnoga tijela, uvučenoga ruba i ravnoga dna. Gornji dio zdjele ukrašen je vodoravnim kaneliranjem. Vanjska i unutarnja površina su tamnosmeđe boje i uglačane obrade.

Institut za arheologiju, PN 7.

Zdjela (3) zaobljenoga tijela i uvučenoga ruba pronađena je u ulozi poklopca na žari, dnom okrenutim prema gore.

\section{POT (PI. 2: 4)}

Ceramic; height: $12.1 \mathrm{~cm}$; maximum width: $12.7 \mathrm{~cm}$; rim diameter: $10.5 \mathrm{~cm}$; bottom diameter: $8.1 \mathrm{~cm}$.

A pot with a spherical body, flat rim, and flat bottom. Its widest part is decorated with a horizontal series of fingerprints alternating with four small protrusions serving as handles. The outside and the inside are brown and smoothly worked. It was found in urn SF 1.

Institute of Archaeology, SF 8.

The larger urn (1) found in grave 1 has parallels in a nocontext find from the site of Lijeva Bara in Vukovar (MetznerNebelsick 2002: PI. 112: 1) and in the finds from Dalj, grave 9, 1911 Panišić vineyard (Hoffiller 1938: PI. 2: 4; Vinski-Gasparini 1973: PI. 115: 4; Metzner-Nebelsick 2002: PI. 67: 4), and also among the no-context finds from Batina (Metzner-Nebelsick 2002: PI. 2: 1) and in more recent excavations at this site, which identified a similar urn in grave 37 , dated to the turn of the IIIb/IV horizon accordingo to the periodization of C. Metzner-Nebelsick (Bojčić et al. 2018: 170, 177, PI. 2: 3). Graves 51, 95, 105, and 117 in Doroslovo contained pots of similar shapes (Trajković 2008: grave 51, 1; grave 95, 1; grave 105,1 ; grave 117, 2), which served as urns too. A similar urn was found on the Žarkovac site in Erdut (Minichreiter 1985: 26-27, PI. XVI: 1). The closest parallels were found in grave 1911/9 in the Panišić vineyard in Dalj and in the mentioned grave from Erdut, characteristic of phase IIIb after $C$. Metzner-Nebelsick, which leads to the conclusion that such pots serving as urns were used in phase $\mathrm{Ha} \mathrm{C1b}$ (MetznerNebelsick 2002: 175, Fig. 75: 6).

The smaller pot (2) found in the urn has parallels in Batina, but also in Dalj, in grave 16 in 1910 Pavošević vineyard (Metzner-Nebelsick 2002: PI. 30: 10; 69: 3), and in grave 130 in Doroslovo (Trajković 2008: grob 130, 7). While Batina and Dalj have no detailed contexts of the finds from the graves, this type of pot was placed in the grave in Doroslovo as a recipient for food or drinks. A pot of the same shape, but with four protrusions on the upper part of the body, was discovered in the reconstructed skeletal grave 1 in Šarengrad (Balen-Letunić 2004: 17, 19-20; PI. 6: 2). A smaller pot of that shape with a relief strip decorated with oblique incisions was found in the floor of house 25 in Gradina na Bosutu (Medović, Medović 2011: Fig. 96: 11). On the basis of the find in Doroslovo (Trajković 2008: grob 130, 1-22), this pot shape can be dated to phase IIlb after the periodization of C. Metzner-Nebelsick (2002: 175).

\section{LID}

\section{BOWL - LID (PI. 1: 1)}

Ceramic; height: $14.5 \mathrm{~cm}$; maximum width: $36.0 \mathrm{~cm}$; rim diameter: $31.5 \mathrm{~cm}$; bottom diameter: $8.0 \mathrm{~cm}$.

A bowl with a biconical body, inverted rim, and flat bottom. The upper part of the bowl is decorated with horizontal fluting. The outside and the inside are dark brown and smoothly worked.

Institute of Archaeology, SF 7.

An upside-down bowl (3) with a spherical body and in- 
Ovaj oblik zdjele osobito je brojan na groblju u Doroslovu (Trajković 2008: grob 6, 17; grob 20, 4; grob 33, 2; grob 42, 6; grob 51, 3; grob 58, 2; grob 92, 2; grob 114, 3; grob 117, 3; grob 125, 2; grob 147, 2, 6), gdje je često upotrebljena baš u funkciji poklopca na žari, npr. u grobovima 51, 95, 114, 117 i 125. Ista kombinacija, žare i zdjele poklopca, zabilježena je u grobu 95 u Doroslovu, pri čemu su od priloga još pronađeni kantharos i manji željezni nož (Trajković 2008: grob 95, 1-4). Ovaj tip zdjele istaknut je kao karakteristični oblik IIlb keramičkoga horizonta prema C. Metzner-Nebelsick (2002: Abb. 75: 13).

\section{LONCI}

\section{LONAC (T. 3: 2)}

Keramika; visina: $28,8 \mathrm{~cm}$; najveća širina: $32,0 \mathrm{~cm}$; promjer oboda: $20,0 \mathrm{~cm}$; promjer dna: $11,0 \mathrm{~cm}$.

Lonac bikoničnoga tijela, izvučenoga ljevkastog ruba i ravnoga dna. Najširi dio lonca ukrašen je okomito postavljenim plastičnim rebrima, dok je vrat lonca ukrašen s trima rozetama sastavljenima od malih uboda raspoređenih oko većega kružnog udubljenja s istaknutim središnjim dijelom. Vrat lonca ukrašen je vodoravnom kanelurom i nizom uboda ispod nje. Vanjska površina je crne boje i uglačana je, dok je unutarnja crne boje.

Institut za arheologiju, PN 5.

\section{LONAC (T. 4: 1)}

Keramika; visina: 29,5 cm; najveća širina: 33,0 cm; promjer oboda: 20,2 cm; promjer dna: 9,5 cm.

Lonac bikoničnoga tijela, izvučenoga ljevkastog ruba i ravnoga dna. Najširi dio lonca ukrašen je okomito postavljenim plastičnim rebrima, dok je vrat lonca ukrašen s trima rozetama sastavljenima od malih uboda raspoređenih oko većega kružnog udubljenja s istaknutim središnjim dijelom. Vrat lonca ukrašen je nizom uboda. Vanjska površina je crne boje i uglačana je, dok je unutarnja crne boje.

Institut za arheologiju, PN 4.

\section{LONAC (T. 5: 2)}

Keramika; visina: 37,4 cm; najveća širina: $36,4 \mathrm{~cm}$; promjer oboda: $23,0 \mathrm{~cm}$; promjer dna: 10,2 cm.

Lonac zaobljenoga tijela, naglašenoga ramena, stožastoga vrata, izvučenoga ljevkastog ruba i ravnoga dna. Na naglašenom ramenu ukrašen je metopnim ukrasom sastavljenim od okomitih žljebova u kombinaciji s okomitim plastičnim rebrima s kosim urezima. Na vratu ima vodoravne žljebove ispod kojih je niz okruglih uboda. Vanjska površina je tamnosmeđa i uglačana, pri čemu je rub lonca svjetlosmeđi, dok je unutarnja površina smeđe boje.

Institut za arheologiju, PN 2.

U grobu su kao prilozi pronađena tri lonca. Dva slična lonca (4-5) bikoničnoga tijela i izvučenoga ruba ukrašeni su okomito postavljenim plastičnim rebrima na najširem dijelu trbuha te kaneliranim vodoravnim ukrasom na vratu ispod kojega se na ramenu nalazi ukras rozeta. Veći lonac (6) za- verted rim was found serving as urn lid. This bowl shape is particularly numerous in the Doroslovo cemetery (Trajković 2008: grave 6, 17; grave 20,4; grave 33, 2; grave 42, 6; grave 51, 3; grave 58, 2; grave 92, 2; grave 114, 3; grave 117, 3; grave 125,2 ; grave 147, 2, 6), where it was often used as urn lid, e.g. in graves $51,95,114,117$, and 125 . The same combination of an urn and a lid bowl was uncovered in grave 95 in Doroslovo, where other goods included a kantharos and a small iron knife (Trajković 2008: grave 95, 1-4). This bowl type has been singled out as a characteristic form of the IIlb ceramic horizon after C. Metzner-Nebelsick (2002: Fig. 75: 13).

\section{POTS}

\section{POT (PI. 3: 2)}

Ceramic; height: $28.8 \mathrm{~cm}$; maximum width: $32.0 \mathrm{~cm}$; rim diameter: $20.0 \mathrm{~cm}$; bottom diameter: $11.0 \mathrm{~cm}$.

A pot with a biconical body, an everted funnel rim, and a flat bottom. The widest part of the pot is decorated with vertical relief ribs, while the pot neck is decorated with three rosettes consisting of small stabs around a larger round depression with the protruding central part. The pot neck is decorated with horizontal fluting and a series of stabs under it. The outside is black and polished, while the inside is black.

Institute of Archaeology, SF 5.

\section{POT (PI. 4: 1)}

Ceramic; height: $29.5 \mathrm{~cm}$; maximum width: $33.0 \mathrm{~cm}$; rim diameter: $20.2 \mathrm{~cm}$; bottom diameter: $9.5 \mathrm{~cm}$.

A pot with a biconical body, an everted funnel rim, and a flat bottom. The widest part of the pot is decorated with vertical relief ribs, while the pot neck is decorated with three rosettes consisting of small stabs around a larger round depression with the protruding central part. The pot neck is decorated with a series of stabs. The outside is black and polished, while the inside is black.

Institute of Archaeology, SF 4.

\section{POT (PI. 5: 2)}

Ceramic; height: $37.4 \mathrm{~cm}$; maximum width: $36.4 \mathrm{~cm}$; rim diameter: $23.0 \mathrm{~cm}$; bottom diameter: $10.2 \mathrm{~cm}$.

A pot with a spherical body, emphasized shoulder, conical neck, everted funnel rim, and a flat bottom. The emphasized shoulder is decorated with a metope decoration consisting of vertical grooves combined with vertical relief ribs with oblique incisions. The neck has horizontal grooves with a series of round stabs under it. The outside is dark brown and polished, the pot rim is light brown, and the interior is brown.

Institute of Archaeology, SF 2.

The grave contained three pots as grave goods. Two similar pots (4-5) with a biconical body and everted rim are decorated with vertical relief ribs on the widest part of the belly, a fluted horizontal decoration on the neck, and a rosette decoration on the shoulder under the neck. The larger pot (6) with a spherical belly and biconical body is decorated with zones of vertical fluting, each of them with a deco- 
obljenoga trbuha i bikoničnoga tijela ukrašen je zonama okomitih kanelura u čijoj sredini je po jedno plastično rebro s ukrasom.

Usporedbe za dva slična lonca (4-5) zabilježene su na nalazištima daljske grupe. Lonac koji ima jedan vodoravni niz okruglih otisaka na vratu pojavljuje se u Dalju, grob 9 vinograd Panišić 1909 (Hoffiller 1938: PI. 7: 1; Metzner-Nebelsick 2002: PI. 65: 1). Ovaj lonac ima i ukras motivom utisnutih rozeta, što na loncima ovog tipa iz Batine (Metzner-Nebelsick 2002: PI. 47: 6; Bojčić et al. 2018: T. 4: 4) i Doroslova (Trajković 2008: grob 15, 1, 4; grob 92, 3; grob 132, 1; grob 147, 3) izostaje. Rozete su zamijećene na drugome tipu lonca s kraćim vratom iz groba Vikendica Matej u Batini (Metzner-Nebelsick 2002: PI. 46: 4). Ukras otisnutih rozeta i kombinacija vodoravnih kanelura i otisaka na vratu posude pojavljuje se na prostoru Štajerske, u 2. fazi naselja na Pošteli te na naselju Brinjeva gora (Teržan 1990: 35-36, Fig. 2: 2; 4: 25; PI. 11: 6; 19: 8; 42: 1, 4). Druga faza naselja datirana je u kraj 8. i rano 7. st. pr. Kr. (Teržan 1990: 36). Drugi sličan lonac razlikuje se u nizu od dvije vodoravne kanelure ispod kojih je niz vodoravnih okruglih otisaka na vratu posude. Lonci s ukrašenim vratom, najčešće nizom vodoravnih kanelura, pronađeni su u Dalju, u grobu 10 vinograd Panišić 1911 (Hoffiller 1938: PI. 5: 5; Metzner-Nebelsick 2002: Pl. 67: 1) i Doroslovu (Trajković 2008: grob 7, 3-4; grob 42, 4; grob 110, 2; grob 9 (1963), 2). Takvi lonci mogu se datirati u horizont IIlb prema grobnim cjelinama karakterističnima za taj keramički horizont prema podjeli C. Metzner-Nebelsick. Inače, ovaj tip posude kao i iste zone ukrasa na tijelu pojavljuju se već ranije u IIla horizontu (Metzner-Nebelsick 2002: 175, Abb. 74: 3; 75: 2-3), pri čemu lonci pronađeni u grobu 1 u Sotinu svojim oblikom više sliče starijim tipovima posuda.

Veći lonac (6) ima usporedbe prema obliku i zonama ukrasa u Dalju (Vinski-Gasparini 1973: T. 115: 6; Hoffiller 1938: PI. 4: 6; 7: 2; grob 3 vinograd Panišić 1909 - MetznerNebelsick 2002: PI. 64: 11) i Doroslovu (Trajković 2008: grob 20, 2; grob 33, 5; grob 125, 5; grob 134, 1; grob 137, 3; grob 9 (1963), 1). Ukras vodoravnih kanelura i nizova uboda ispod njih položenih na vratu pojavljuje se na loncima s groblja u Donjoj Dolini, npr. u grobu 46 na gredi Mate Petrovića mlađeg (Truhelka 1904: 102, T. LII: 7) kao i na loncu iz groba 21 s grede Nikole Šokića I u Donjoj Dolini (Truhelka 1904: 115, T. LXVI: 2). Usporedbe prema tipu ukrasa mogu se potražiti prema zapadu, odnosno na prostoru Donje Doline i Požeške kotline na lokalitetu Gložđe (Potrebica 2003: 224, T. VI). Kompozicija ukrasa okomitih kanelura i okomitoga plastičnog rebra s kosim urezima zabilježena je u naselju bosutske grupe Farkađin u južnome Banatu (Medović 1978: 64, T. CVIII: 10). Isto tako, u grobu 137 iz Doroslova pronađen je sličan lonac koji se smatra tipičnim za keramički horizont IIIb prema C. Metzner-Nebelsick (2002: 175, Abb. 75). Stoga se opisani tip lonca može datirati u Illb horizont, što pokazuju i usporedbe iz Donje Doline gdje se pojavljuje u grobovima najstarijega horizonta groblja, što odgovara Ha C2 stupnju (Čović 1987: 240). rated relief rib in the middle.

Comparisons for two similar pots (4-5) have been recorded at the Dalj group sites. A pot with a horizontal series of round prints on the neck was found in Dalj, grave 9, 1909 Panišić vineyard (Hoffiller 1938: PI. 7: 1; Metzner-Nebelsick 2002: PI. 65: 1). Moreover, this pot has an impressed rosette decoration, which is missing from the pots of this type from Batina (Metzner-Nebelsick 2002: PI. 47: 6; Bojčić et al. 2018: PI. 4: 4) and Doroslovo (Trajković 2008: grave 15, 1, 4; grave 92 , 3; grave 132, 1; grave 147, 3). Also, rosettes were noticed on another type of pot with a shorter neck from the Vikendica Matej grave in Batina (Metzner-Nebelsick 2002: PI. 46: 4). A decoration of printed rosettes and combinations of horizontal fluting and prints on the neck of the vessel appears on the territory of Styria, in the $2^{\text {nd }}$ phase of the Poštela settlement, and in the settlement of Brinjeva gora (Teržan 1990: 35-36, Fig. 2: 2; 4: 25; PI. 11: 6; 19: 8; 42: 1, 4). The second phase of the settlement has been dated to the end of the $8^{\text {th }}$ century and the early $7^{\text {th }}$ cent. BC (Teržan 1990: 36). Another similar pot differs in the series of two horizontal flutes above a series of horizontal round prints on the neck of the vessel. Pots with a decorated neck, usually with a series of horizontal fluting, were found in Dalj, in grave 10 of 1911 Panišić vineyard (Hoffiller 1938: PI. 5: 5; MetznerNebelsick 2002: PI. 67: 1) and in Doroslovo (Trajković 2008: grave 7, 3-4; grave 42, 4; grave 110, 2; grave 9 (1963), 2). Such pots can be dated to the IIIb horizon on the basis of funerary complexes characteristic for this ceramic horizon after the classification of C. Metzner-Nebelsick. This vessel type and the same decoration zones on the body appear in the Illa horizon already (Metzner-Nebelsick 2002: 175, Fig. 74: 3; 75: $2-3 ;$ ), and the pots found in grave 1 in Sotin have a shape that looks more like older vessel types.

The shape and decoration zones of the larger pot (6) have parallels in Dalj (Vinski-Gasparini 1973: PI. 115: 6; Hoffiller 1938: PI. 4: 6; 7: 2; grave 3 of 1909 Panišić vineyard - Metzner-Nebelsick 2002: PI. 64: 11) and Doroslovo (Trajković 2008: grave 20, 2; grave 33, 5; grave 125, 5; grave 134, 1; grave 137, 3; grave 9 (1963), 1). The decoration of horizontal fluting above a series of stabs on the neck appears on the pots from the Donja Dolina cemetery, e.g. in grave 46 on the greda of Mate Petrović the younger (Truhelka 1904: 102, PI. LII: 7) and on the pot from grave 21 from the greda of $\mathrm{Ni}$ kola Šokić I in Donja Dolina (Truhelka 1904: 115, PI. LXVI: 2). Comparisons for the decoration type can be sought further west, in the area of Donja Dolina and at the Gložđe site in the Požega Valley (Potrebica 2003: 224, PI. VI). The composition of the vertical fluting decorations and the vertical relief rib with oblique incisions was recorded in the Bosut group settlement of Farkađin in southern Banat (Medović 1978: 64, PI. CVIII: 10). Also, grave 137 from Doroslovo contained a similar pot that is considered to be typical for the ceramic horizon IIlb after C. Metzner-Nebelsick (2002: 175, Fig. 75). Therefore, the described pot type can be dated to the IIlb horizon, as indicated by the parallels from Donja Dolina, where it appears in the graves from the oldest horizon of the cemetery, which matches phase Ha C2 (Čović 1987: 240). 


\section{RECIPIJENTI ZA PIĆE}

\section{KANTHAROS (T. 5: 1)}

Keramika; visina: $7,1 \mathrm{~cm}, 7,4 \mathrm{~cm}$ s ručkama; najveća širina: 10,0 cm; promjer oboda: 5,5 cm; promjer dna: $3,4 \mathrm{~cm}$; širina ručki: $1,8 \mathrm{~cm}$.

Kantharos bikoničnoga tijela, stožastoga vrata, ravnoga ruba i ravnoga dna, $s$ dvije trakaste ruke. Naglašeno rame kantharosa ukrašeno je metopama sastavljenim od okomitih kanelura i udubljenja koja su najvjerojatnije izvedena prstom. Vanjska površina je smeđe boje i uglačane obrade, a unutarnja tamnosmeđe boje. Kantharos je pronađen u loncu PN 2.

Institut za arheologiju, PN 48.

Kantharos (7) je pronađen u većem loncu (6) te pripada među manje kantharose na prostoru Podunavlja. Najsličnije usporedbe zabilježene su u Dalju (Hoffiller 1938: PI. 13: 2) i Doroslovu (Trajković 2008: grob 115, 3; grob 130, 11; grob 131, 8; grob 15 (1963)). Metopni ukras s nizovima okomitih kanelura na kantharosima s nalazišta daljske grupe većinom se pojavljuje u vrijeme starijega željeznog doba (MetznerNebelsick 2002: Abb. 68-69). Prema grobu 130 iz Doroslova, koji je opisan kao tipičan grob keramičkoga horizonta IIIb (Metzner-Nebelsick 2002: 175), kantharos se može datirati u Ha C1b stupanj prema Ch. Pareu (1998: 404, Tab. 5).

\section{8. ŠALICA (T. 3: 1)}

Keramika; visina: 4,4 cm, 5,5 cm s ručkom; najveća širina: 9,1 cm; promjer oboda: $8,5 \mathrm{~cm}$; promjer dna: $2,2 \mathrm{~cm}$; promjer ručke: $1,5 \mathrm{~cm}$.

Šalica zaobljenoga tijela, ljevkastoga vrata, s ručkom okrugloga presjeka koja nadvisuje rub i omfalos dnom. $\mathrm{Na}$ najširem dijelu ukrašena je $s$ naizmjenično postavljenim bradavičastim izdancima i tri otiska prsta. Dno je s unutarnje strane ukrašeno okruglim otiscima. Vanjska površina je smeđe boje i uglačana je, dokje unutarnja tamnosmeđe boje i uglačane obrade. Pronađena je u loncu PN 5.

Institut za arheologiju, PN 15.

Oblikom slična šalica pronađena je u Dalju (Hoffiller 1938: Pl. 23: 3), zatim u grobu 2b/1970 u Batini (Metzner-Nebelsick 2002: T. 47: 1) te na naselju Gradina na Bosutu (Medović, Medović 2011: sl. 37: 2). Sličan ukras otiscima zabilježen je na kantharosu iz Dalja (Hoffiller 1938: PI. 13: 7). Šalica iz groba 1 oblikom pripada lokalnome obliku šalica koje su ukrašene na različite načine (urezivanjem, otiskivanjem), a pojavljuju se od Kalakača horizonta bosutske grupe (Medović 1978: 25, T. XLII: 5).

\section{ZDJELE}

U grobu su, osim zdjele - poklopca, pronađene još dvije zdjele od kojih su obje ukrašene kosim plitkim kanelurama. Jedna zdjela je dubljega (9), a druga plićega recipijenta (10).

\section{ZDJELA (T. 6: 1)}

Keramika; visina: $7,4 \mathrm{~cm}$; najveća širina: $24,0 \mathrm{~cm}$; promjer oboda: 20,0 cm; promjer dna: 6,2 cm.

Zdjela bikoničnoga tijela, uvučenoga ruba i ravnoga

\section{DRINK RECIPIENTS}

7. KANTHAROS (PI. 5: 1)

Ceramic; height: $7.1 \mathrm{~cm}, 7.4 \mathrm{~cm}$ with handles; maximum width: $10.0 \mathrm{~cm}$; rim diameter: $5.5 \mathrm{~cm}$; bottom diameter: 3.4 $\mathrm{cm}$; handle width: $1.8 \mathrm{~cm}$.

A kantharos with a biconical body, conical neck, flat rim, and flat bottom, and with two strap handles. The emphasized shoulder of the kantharos is decorated with metopes consisting of vertical fluting and depressions that were most probably made with a finger. The outside is brown and polished; the inside is dark brown. The kantharos was found in pot SF 2.

Institute of Archaeology, SF 48.

The kantharos (7) was found in a larger pot (6) and belongs to smaller kantharoi in the Danube Basin. The closest parallels have been recorded in Dalj (Hoffiller 1938: Pl. 13: 2) and Doroslovo (Trajković 2008: grave 115, 3; grave 130, 11; grave 131, 8; grave 15 (1963)). The metope decoration with series of vertical fluting on the kantharoi from the Dalj group site mostly appears during the Early Iron Age (MetznerNebelsick 2002: Figs. 68-69). On the basis of grave 130 from Doroslovo, described as a typical grave of the ceramic horizon Illb (Metzner-Nebelsick 2002: 175), the kantharos can be dated to phase Ha C1b after Ch. Pare (1998: 404, Tab. 5).

\section{CUP (PI. 3: 1)}

Ceramic; height: $4.4 \mathrm{~cm}, 5.5 \mathrm{~cm}$ with the handle; maximum width: $9.1 \mathrm{~cm}$; rim diameter: $8.5 \mathrm{~cm}$; bottom diameter: $2.2 \mathrm{~cm}$; handle diameter: $1.5 \mathrm{~cm}$.

A cup with a spherical body, funnel neck, and a handle with a round cross-section rising over the rim and omphalos with its bottom. Its widest part is decorated with alternating wart-like protrusions and three fingerprints. The interior of the bottom is decorated with round prints. The outside is brown and polished; the inside is dark brown and polished. It was found in pot SF 5 .

Institute of Archaeology, SF 15.

A cup with a similar shape was found in Dalj (Hoffiller 1938: Pl. 23: 3), in grave 2b/1970 in Batina (Metzner-Nebelsick 2002: Pl. 47: 1), and at the site of Gradina na Bosutu (Medović, Medović 2011: Fig. 37: 2). A similar print decoration was recorded on the kantharos from Dalj (Hoffiller 1938: PI. 13: 7). The shape of the cup from grave 1 belongs to the local shape of cups which are decorated in different ways (incisions, prints) and which appeared in the Kalakača horizon of the Bosut group (Medović 1978: 25, PI. XLII: 5).

\section{BOWLS}

Aside from the bowl lid, the grave contained another two bowls, both decorated with oblique shallow fluting. One bowl has a deeper recipient (9) and the other has a shallower one (10).

\section{BOWL (PI. 6: 1)}

Ceramic; height: $7.4 \mathrm{~cm}$; maximum width: $24.0 \mathrm{~cm}$; rim diameter: $20.0 \mathrm{~cm}$; bottom diameter: $6.2 \mathrm{~cm}$.

A bowl with a biconical body, inverted rim, and a flat 
dna. Gornji dio zdjele ukrašen je kosim kaneliranjem. Vanjska i unutarnja površina su tamnosmeđe boje i uglačane obrade.

Institut za arheologiju, PN 3.

\section{ZDJELA (T. 6: 2)}

Keramika; visina: $6,0 \mathrm{~cm}$; najveća širina: $21,5 \mathrm{~cm}$; promjer oboda: 19,0 cm; promjer dna: 5,7 cm

Zdjela bikoničnog tijela, uvučenog ruba i ravnog dna. Gornji dio zdjele ukrašen je kosim kaneliranjem. Vanjska i unutarnja površina su tamnosmeđe boje i uglačane obrade.

Institut za arheologiju, PN 6.

Zdjele zaobljenoga tijela i uvučenoga ruba, koje su ukrašene na ovaj način, pojavljuju se u grobovima u Batini (Metzner-Nebelsick 2002: PI. 4: 14; 47: 2), zatim u grobu 7 vinograd Pavošević u Dalju (Hoffiller 1938: 13-14, PI. 28: 2; 31: 2) i Doroslovu (Trajković 2008: grob 133, 9; grob 17 (1963), 3). U većini grobova u Doroslovu ovakve zdjele imaju vodoravne kanelure. Ovakve zdjele plićega i dubljega recipijenta te ukrašene kosim plitkim kaneliranjem česte su u naseljima bosutske grupe (Medović 1978: 30, T. CXX; CXXIV; Popović 1981: 25, T. XXXVI; XVIII: 7). Takva je zdjela pronađena na podnici kuće 26 na Gradini na Bosutu s keramičkim nalazima kasnoga Kalakača i ranoga Basarabi horizonta (Medović, Medović 2011: 107-108, sl. 99: 10), no česte su i među oblicima zdjela IV. horizonta koji je datiran u vrijeme Basarabi stila (Medović, Medović 2011: 271, sl. 256). Opisane zdjele C. Metzner-Nebelsick datira u horizont IIIb do u horizont IV (2002: 172-177, Abb. 75: 13; 76: 7).

\section{POSTOLJE}

\section{POSTOLJE (T. 6: 3)}

Keramika; visina: $10,8 \mathrm{~cm}$; najveća širina: $16,1 \mathrm{~cm}$; promjer otvora na vrhu: 6,6 cm; promjer otvora na dnu: $15,4 \mathrm{~cm}$.

Šuplje postolje stožastoga oblika s cilindričnim središnjim dijelom. Vanjska i unutarnja površine su oker-smeđe boje i glatke obrade. Na njemu je bila zdjela PN 6.

Institut za arheologiju, PN 9.

U grobu je pronađeno keramičko postolje na kojem se nalazila plitka zdjela (5). Keramička postolja pojavljuju se u grobovima daljske grupe. Zabilježeni su u Dalju kao u grobu 85, vinograd Poštić 1909 (Metzner-Nebelsick 2002: T. 61: 8). Primjerak iz Dalja ukrašen je urezanim šrafiranim trokutima. Zdjele na nozi češće su na groblju u Doroslovu gdje se, $s$ druge strane, ne pojavljuju postolja (Trajković 2008: grob 6, 18,20 , passim). U Batini se pojavljuju i zdjele na nozi basarapskoga tipa (Dizdar et al. 2019: 106, Figs. 10-11). Keramička postolja često se pojavljuju na halštatskim nalazištima jugoistočnoalpskoga kruga, npr. u Molniku, na položaju Grmada u grobu 17/6; u Ljubljani i Mengešu (Škvor Jernejčić 2017: 96, Fig. 88; PI. 27: 17, 20). Primjerci keramičkih postolja pojavljuju se na prostoru od Donjega Podunavlja pa sve do jugoistočnoalpskoga svijeta i sjevernoitalskoga prostora (Metzner-Nebelsick 1992: 366-369, Abb. 6, Karte 4). Sotinskome primjerku najsličniji su nalazi iz Dalja, Molnika i Joisa u Gradišću, s malom razlikom da postolja iz Sotina i Joisa bottom. The upper part of the bowl is decorated with oblique fluting. The outside and the inside are dark brown and polished.

Institute of Archaeology, SF 3.

\section{BOWL (PI. 6: 2)}

Ceramic; height: $6.0 \mathrm{~cm}$; maximum width: $21.5 \mathrm{~cm}$; rim diameter: $19.0 \mathrm{~cm}$; bottom diameter: $5.7 \mathrm{~cm}$

A bowl with a biconical body, inverted rim, and a flat bottom. The upper part of the bowl is decorated with oblique fluting. The outside and the inside are dark brown and polished.

Institute of Archaeology, SF 6.

Bowls with a spherical body and inverted rim, which are decorated this way, appear in graves in Batina (MetznerNebelsick 2002: PI. 4: 14; 47: 2), in grave 7 of the Pavošević vineyard in Dalj (Hoffiller 1938: 13-14, PI. 28: 2; 31: 2), and in Doroslovo (Trajković 2008: grave 133, 9; grave 17 (1963), 3). In most graves in Doroslovo, such bowls have horizontal fluting. These bowls with a shallower or deeper recipient, decorated with oblique shallow fluting, are frequent in Bosut group settlements (Medović 1978: 30, PI. CXX; CXXIV; Popović 1981: 25, PI. XXXVI; XVIII: 7). Such a bowl was found in the floor of house 26 at Gradina na Bosutu with ceramic finds of the late Kalakača and early Basarabi horizons (Medović, Medović 2011: 107-108, Fig. 99: 10), but they are also frequent among the shapes of the vessels from the IV horizon, dated to the Basarabi style period (Medović, Medović 2011: 271, Fig. 256). The described bowls were dated by $C$. Metzner-Nebelsick to between horizon IIIb and horizon IV (2002: 172-177, Fig. 75: 13; 76: 7).

\section{STAND}

\section{STAND (PI. 6: 3)}

Ceramic; height: $10.8 \mathrm{~cm}$; maximum width: $16.1 \mathrm{~cm}$; diameter of the top opening: $6.6 \mathrm{~cm}$; diameter of the bottom opening: $15.4 \mathrm{~cm}$.

A hollow stand with a conical shape and a cylindrical central part. The outside and the inside are ochre brown and smoothed out. It used to be the stand for bowl SF 6 .

Institute of Archaeology, SF 9.

The grave contained a ceramic stand topped by a shallow bowl (5). Ceramic stands appear in the graves of the Dalj group. They have been found in Dalj and in grave 85, 1909 Poštić vineyard (Metzner-Nebelsick 2002: PI. 61: 8). The item from Dalj is decorated with incised hatched triangles. Bowls with a foot are more frequent in the Doroslovo cemetery, but it contains no stands (Trajković 2008: grave 6, 18, 20, passim). Batina also includes Basarabi-type bowls with a foot (Dizdar et al. 2019: 106, Figs. 10-11). Ceramic stands often appear on the Hallstatt sites of the south-eastern Alpine sphere, e.g. in Molnik, on the Grmada site in grave 17/6; in Ljubljana and Mengeš (Škvor Jernejčić 2017: 96, Fig. 88; PI. 27: 17, 20). Items of ceramic stands appear on the territory of lower Danube up to the south-eastern Alpine world and the north Italic region (Metzner-Nebelsick 1992: 366-369, Fig. 6, Map 4). The item from Sotin has the closest parallels in the finds from Dalj, Molnik and Jois in Burgenland, with 
nisu ukrašena (Metzner-Nebelsick 1992: Abb. 6: 3-4, 8). Keramička postolja datirana su od Ha B3 do u Ha C vrijeme, odnosno od 9. do 7. st. pr. Kr. Prema kontekstu u grobovima, pretpostavlja se kako su postolja imala funkcionalnu ulogu za posude koje su bile odlagane na njih i ispod kojih se vatrom ili nekim drugim izvorom održavala toplina sadržine u šalicama, kantharosima ili zdjelama (Metzner-Nebelsick 1992: 368). Dok su u Molniku u grobu 17/6 pronađeni kantharosi na postoljima, u Sotinu je na postolje bila stavljena plitka zdjela. Na tim primjerima možda su vidljive razlike u korištenju različitih recipijenata, a možda i sadržina u pogrebnim običajima. Nalaz postolja u grobu 1 u Sotinu, koji je antropološkom analizom određen kao grob odrasle žene i djeteta, pokazatelj je kako upotreba postolja vjerojatno nema veze sa spolom pokojnika (Metzner-Nebelsick 1992: 368), nego možda prije s njegovim ili njezinim statusom $u$ zajednici ili specifičnim dijelom pogrebnoga običaja koji nije primjenjivan na sve članove zajednice.

\section{PRŠLJEN}

\section{PRŠLJEN (T. 2: 3)}

Keramika; visina: 1,7 cm; promjer: 2,1 cm.

Pršljen bikoničnoga oblika.

Institut za arheologiju, PN 13.

Keramički pršljen bikoničnoga oblika malih dimenzija pronađen je u žari među spaljenim kostima pokojnice. Takva dva mala pršljena pronađena su u grobovima $110 \mathrm{i}$ 138 u Doroslovu (Trajković 2008: 117; grob 110, 7-8; grob $138,20)$. Oblikom se pršljen iz Sotina uklapa u tip pršljena koji je bio u upotrebi na prostoru grupe Dalj. Bikonični pršljeni poznati su iz Dalja (Metzner-Nebelsick 2002: 667, PI. 65: 5), Erduta (Metzner-Nebelsick 2002: 687, PI. 106: 7) i Batine (Metzner-Nebelsick 2002: 599, PI. 5: 11; Hršak et al. 2017: 41-42, Figs. 2-3; Bojčić et al. 2018: 166-167, T. 1: 1). Na groblju u Doroslovu u grobovima se također najčešće nalazi prilog po jednoga ili dva pršljena, pri čemu su oni bikoničnoga oblika najbrojniji (Vasić 2008: 342; Trajković 2008: grob 6, 5-10, passim). Neukrašeni bikonični pršljeni pojavljuju se tijekom Kalakača horizonta (Bosut IVa) u naselju Gradina na Bosutu (Medović, Medović 2011: 282, sl. 258: 1, 4).

Zanimljivo je kako se pršljeni pojavljuju na prostoru jugoistočne Panonije, zatim istočnoalpskome prostoru kao i na prostoru sjeverne Bosne u Donjoj Dolini. Oni nisu čest prilog u grobovima na glasinačkom prostoru i području Basarabi kulture, kao niti na prostoru Füzesabony-Mezőscát grupe u susjednoj Mađarskoj. To je jasna kulturološka razlika koju je istaknula C. Metzner-Nebelsick (2002: 201). Male dimenzije i težina pršljena pronađenoga u grobu 1 u Sotinu mogu posvjedočiti o izradi fine vunene pređe koja je bila uobičajena u halštatsko vrijeme (Grömer 2016: 87).

\section{FIBULA}

Dijelovi dvopetljaste lučne fibule s čvorovima pronađeni su razlomljeni i pomiješani sa spaljenim kostima u žari u grobu 1. Tijekom konzervacije, fibula je rekonstruirana u cijelosti, pri čemu je zamijećeno kako se radi o fibuli tipa $6 a$ prema S. Gabrovcu (1970: 28-29, karta 9). a slight difference: the stands from Sotin and Jois are not decorated (Metzner-Nebelsick 1992: Fig. 6: 3-4, 8). The ceramic stands have been dated to the period from $\mathrm{Ha} B 3$ to $\mathrm{HaC}$, from the $9^{\text {th }}$ to the $7^{\text {th }}$ cent. BC. On the basis of grave contexts, it is assumed that the stands had a functional role for the vessels laid on them and had fire or some other heat source under them to maintain the warmth of the contents of cups, kantharoi or bowls (Metzner-Nebelsick 1992: 368). While grave 17/6 in Molnik contained kantharoi on stands, the stand in Sotin was topped by a shallow bowl. These examples might show the differences in using different recipients, and maybe also the content of funerary rites. The find of the stand in grave 1 in Sotin, which was identified as the grave of an adult woman and child through anthropological analysis, shows that the use of a stand is probably unrelated to the sex of the deceased (Metzner-Nebelsick 1992: 368), but rather to his or her status in the community or a particular part of the funerary rite which was not applied to all community members.

\section{SPINDLE-WHORL}

\section{SPINDLE-WHORL (PI. 2: 3)}

Ceramic; height: $1.7 \mathrm{~cm}$; diameter: $2.1 \mathrm{~cm}$.

A spindle-whorl of biconical shape.

Institute of Archaeology, SF 13.

A small ceramic spindle-whorl of biconical shape was found among the cremated remains of a woman in an urn. Such two small spindle-whorls were found in graves 110 and 138 in Doroslovo (Trajković 2008: 117; grave 110, 7-8; grave 138,20$)$. The shape of the Sotin spindle-whorl matches the spindle-whorl type that was in use in the area of the Dalj group. Biconical spindle-whorls are known from Dalj (Metzner-Nebelsick 2002: 667, PI. 65: 5), Erdut (Metzner-Nebelsick 2002: 687, Pl. 106: 7), and Batina (Metzner-Nebelsick 2002: 599, PI. 5: 11; Hršak et al. 2017: 41-42, Figs. 2-3; Bojčić et al. 2018: 166-167, PI. 1: 1). Also, the graves in the Doroslovo cemetery most often include one or two spindle-whorls each, with biconical spindle-whorls being the most numerous (Vasić 2008: 342; Trajković 2008: grave 6, 5-10, passim). Undecorated biconical spindle-whorls appear during the Kalakača horizon (Bosut IVa) in the settlement of Gradina na Bosutu (Medović, Medović 2011: 282, Fig. 258: 1, 4).

Interestingly, the spindle-whorls appear in the south-eastern Pannonia, the eastern Alpine region, and the area of northern Bosnia in Donja Dolina. They are not a frequent grave good in the Glasinac territory and the area of the Basarabi culture, nor in the area of the Füzesabony-Mezőscát group in neighbouring Hungary. It is a clear culturological difference, pointed out by C. Metzner-Nebelsick (2002: 201). The small size and weight of the spindle-whorl found in grave 1 in Sotin may testify about the production of fine wool yarn that was common in the Hallstatt period (Grömer 2016: 87).

\section{FIBULA}

Parts of a double loop knobbed bow fibula were found broken and mixed together with cremated bones in an urn in grave 1. During the conservation, the fibula was reconstructed in its entirety, and it was identified as a type 6a fibula after S. Gabrovec (1970: 28-29, Map 9). 


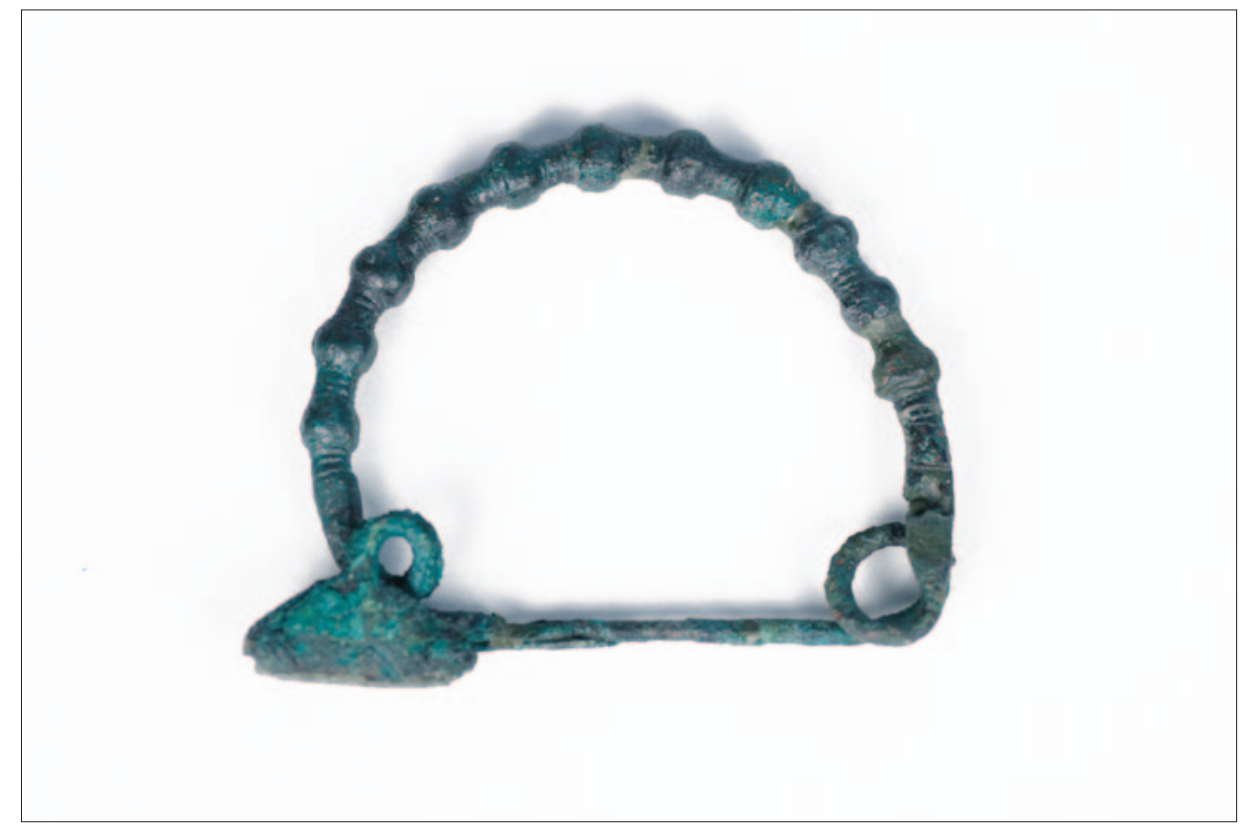

Sl. 4 Fibula iz groba 1 u Sotinu (snimio: Design D studio, Vukovar)

Fig. 4 Fibula from grave 1 in Sotin (photo: Design D studio, Vukovar)

\section{FIBULA (T. 2: 1; sl. 4)}

Bakrena slitina; visina: $5,5 \mathrm{~cm}$; dužina: $7,0 \mathrm{~cm}$; promjer luka: 0,4 cm; promjer čvorova: 0,6 cm.

Dvopetljasta lučna fibula $s$ jedanaest čvorova na luku između kojih su urezane vodoravne linije. Fibula ima trokutastu nisku nožicu ukrašenu urezanim trokutastim ornamentom. Prijelaz iz petlje u luk fibule trubljasto je izveden. Spirala i igla spojeni su dvjema zakovicama. Fibula pripada tipu 6a prema S. Gabrovcu.

Institut za arheologiju, PN 10-12.

Geografski slične paralele fibuli nalaze se na području grupe Dalj. To su slučajni nalaz fibule iz Batine koja ima isti način spajanja luka i igle kao i sitne tragove urezivanja između kuglica (Márton 1913: PI. 6: 34; Vinski, Vinski-Gasparini 1962: 276, sl. 108; Metzner-Nebelsick 2002: 621, T. 32: 9) te primjerci iz Naka u južnome dijelu Transdanubije (Márton 1913: T. 6: 36-37; Patek 1981: 191, Pl. 2: 17). E. Patek ih je povezala u grupu nalaza koja pokazuje veze Transdanubije s južnim dijelom srednjega Podunavlja (Patek 1981: 191). Slična fibula s manjim brojem kuglica na luku pronađena je u grobu iz Soprona 224/1976 koji je datiran u III. fazu groblja, odnosno u početak 7. st. pr. Kr. (Patek 1982: 13, Tab. 1; 1993: Abb. 34). Ukras na nožici fibule iz Soprona istovjetan je motivu koji se pojavljuje na nožici fibule iz Sotina, grob 1 (Patek 1981: 191, PI. 2: 15).

Ove su fibule vrlo brojne na jugoistočnoalpskome području gdje se razlikuje nekoliko varijanti koje se pokušalo povezati s različitim radionicama, npr. tip s čvorovima i rebrima na luku s lokalnom radionicom u Mostu na Soči (Teržan 1990: 98, sl. 20: 3-5, karta 10). K. Vinski-Gasparini je fibule ovoga tipa pripisala horizontu 1 u periodizaciji grupe Martijanec-Kaptol, složivši se s ranijom datacijom već od Ha B3 stupnja koju je predložio S. Gabrovec (Vinski-Gasparini

\section{FIBULA (PI. 2: 1; Fig. 4)}

Copper alloy; height: $5.5 \mathrm{~cm}$; length: $7.0 \mathrm{~cm}$; bow diameter: $0.4 \mathrm{~cm}$; knob diameter: $0.6 \mathrm{~cm}$.

A double loop bow fibula. The bow has eleven knobs alternating with incised horizontal lines. The fibula has a triangular low foot decorated with an incised triangular ornament. The joint of the loop and the bow of the fibula is shaped like a trumpet. The spring and the pin are fastened by means of two studs. The fibula belongs to type 6a after S. Gabrovec.

Institute of Archaeology, SF 10-12.

Geographically similar parallels to the fibula can be found in the area of the Dalj group. They are the chance find of a fibula in Batina, which has the same sort of joint between the bow and the pin, and tiny traces of incisions between the spheres (Márton 1913: PI. 6: 34; Vinski, Vinski-Gasparini 1962: 276, Fig. 108; Metzner-Nebelsick 2002: 621, PI. 32: 9), and items from Nak in the southern part of Transdanubia (Márton 1913: PI. 6: 36-37; Patek 1981: 191, PI. 2: 17). E. Patek classified them in a group of finds showing the connections between Transdanubia and the southern part of the middle Danube Basin (Patek 1981: 191). A similar fibula with fewer spheres on the bow was found in a grave in Sopron, $224 / 1976$, dated to phase III of the cemetery, i.e. to the beginning of the $7^{\text {th }}$ cent. BC (Patek 1982: 13, Tab. 1; 1993: Fig. 34). The decoration on the foot of the Sopron fibula is identical as the motif appearing on the foot of the fibula from Sotin, grave 1 (Patek 1981: 191, PI. 2: 15).

These fibulae are very numerous in the south-east Alpine region, where several variants can be distinguished. It has been tried to associate these variants with different workshops, e.g. the type with the knobs and the ribbed bow has been associated with the local workshop in Most na Soči (Teržan 1990: 98, Fig. 20: 3-5, Map 10). K. Vinski-Gasparini attributed the fibulae of this type to horizon 1 in the periodization of the Martijanec-Kaptol group, agreeing with 


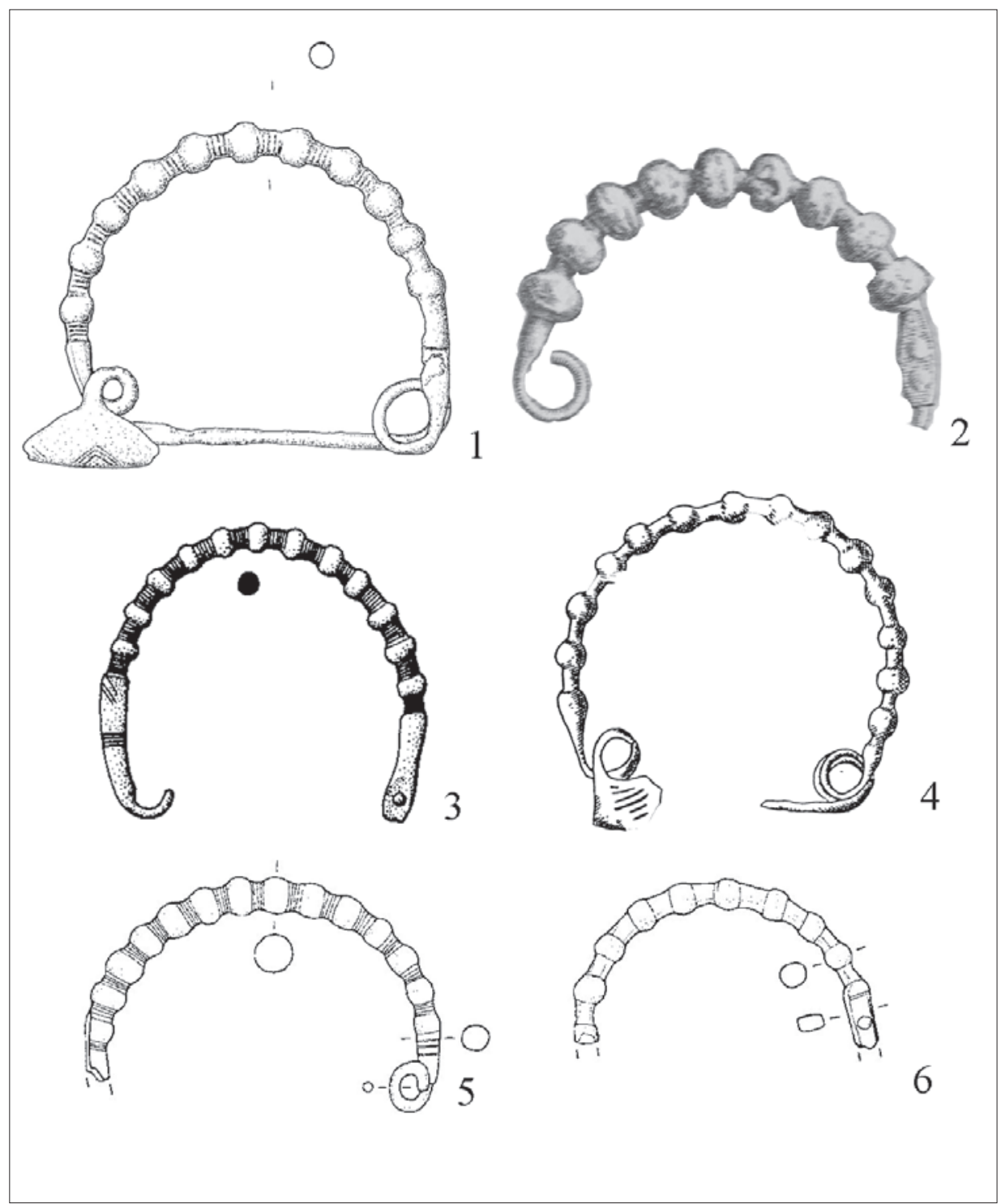

SI. 5 Varijante fibula tipa 6a: 1 Sotin; 2 Batina (prema: Márton 1913); 3-4 Rifnik (prema: Teržan 1990); 5-6 Nova Tabla (prema: Guštin et al. 2017)

Fig. 5 Variants of fibulae of type 6a: 1 Sotin; 2 Batina (after: Márton 1913); 3-4 Rifnik (after: Teržan 1990); 5-6 Nova Tabla (after: Guštin et al. 2017)

1987: 190, sl. 11: 11-12). Njihovu dataciju u početni horizont grobova željeznoga doba u Štajerskoj dokazala je primjerom groba 1903/14 iz Rifnika B. Teržan (1990: 98, sl. 20: 4).

Najsličnija usporedba fibuli iz Sotina (sl. 5) dokumentirana je u spomenutome grobu 1903/14 u Rifniku (Teržan 1990: 98, sl 20: 4). Slične fibule pronađene su u grobovima 10 i 25 u Novoj Tabli kod Murske Sobote (Guštin et al. 2017: 424, 436, grob 10, 1290; grob 25, 1353), zatim u grobu $144 \mathrm{u}$ Rušama (Müller-Karpe 1959: 271, T. 113A: 1) u Štajerskoj kao i u tumulu XX iz Goričana u Međimurju (Vidović 2003: 80, T. 1: 1). Ovaj tip fibula pojavljuje se i u pet starijih grobnih cjelina u Kleinkleinu (Höchschusterwald 1, 2, 12; Ofenmacherwald $33,43)$ te dvije mlađe (Grellwald, Tschoneggerfranzl-Tumulus 2) gdje su datirane u Kleinklein fazu 1, što odgovara Podzemelj 1 i 2 fazi u Sloveniji, odnosno Ha B3/Ha C1 u srednjoeuropskoj kronologiji (Dobiat 1980: 146, 168, T. 1: 12; 6: $5 ; 17: 3 ; 19: 6 ; 91: 14)$. Pojavu ovakvih fibula s čvorovima na lu- the earlier dating to $\mathrm{Ha}$ B3 phase, proposed by S. Gabrovec (Vinski-Gasparini 1987: 190, Fig. 11: 11-12). Their dating to the initial horizon of Iron Age graves in Styria was proven by B. Teržan, who provided the example of grave 1903/14 from Rifnik (1990: 98, Fig. 20: 4).

The closest parallel with the Sotin fibula (Fig. 5) was documented in the mentioned grave 1903/14 in Rifnik (Teržan 1990: 98, Fig 20: 4). Similar fibulae were found in graves 10 and 25 in Nova Tabla near Murska Sobota (Guštin et al. 2017: 424, 436, grave 10, 1290; grave 25, 1353), in grave 144 in Ruše (Müller-Karpe 1959: 271, PI. 113A: 1) in Styria, and in tumulus XX from Goričani in Međimurje (Vidović 2003: 80, PI. 1: 1). This fibula type also appears in five older funerary complexes in Kleinklein (Höchschusterwald 1, 2, 12; Ofenmacherwald 33, 43), and two younger ones (Grellwald, Tschoneggerfranzl-Tumulus 2), where they were dated to the Kleinklein phase 1, which matches the Podzemelj 1 and 2 phase in Slovenia, or $\mathrm{Ha} \mathrm{B} / \mathrm{Ha} \mathrm{C1}$ in the Central European chronology (Dobiat 1980: 146, 168, PI. 1: 12; 6: 5; 17: 3; 
ku i M. Egg ističe u Podzemelj 2 stupnju (Egg, Kramer 2016: 210). U Koruškoj se ove fibule pojavljuju u većem broju na groblju u Frögu (Tomedi 2002: 174) gdje su povezane s radionicama u Koruškoj, Gorenjskoj i Posočju te gornjoj Štajerskoj, dok drugi primjerci pokazuju vezu s Gornjom i Donjom Austrijom, Transdanubijom i Štajerskom (Tomedi 2002: 174, PI. 1B: 1; 116: 1-2). Varijanta koja se pojavljuje u na prostoru Panonije, a koju je S. Gabrovec izdvojio kao tip 6a, razlikuje se od fibula svetolucijske skupine, prije svega po obliku nožice. Da je to važna odrednica u definiranju varijanti slaže se i G. Tomedi (Tomedi 2002: 173) koji zastupa mišljenje kako se ne mogu jasno odijeliti stariji i mlađi tipovi brončanih fibula s kuglicama na luku te se slaže s Gabrovčevom datacijom razvoja dvopetljastih fibula u Podzemelj stupanj (Tomedi 2002: 173). U varijanti fibule iz Sv. Lucije pojavljuje se i urezani ukras između čvorova na luku, kao što je to slučaj i u varijanti fibula s prostora Štajerske. Prema tipologiji B. E. Glunz to je tip C koji ona na groblju u Hallstattu datira prema nalazu iz Magdalenske gore, a koji je S. Gabrovec datirao prije 600. god. pr. Kr., odnosno u Ha C2 vrijeme (Glunz 1997: 46-47, Karte 5). B. E. Glunz također smatra da nema kronološke razlike između jednopetljastih i dvopetljastih fibula s čvorovima na luku (Glunz 1997: 46). Inače, pojava dvopetljastih lučnih fibula s čvorovima na luku može se pratiti do srednjega Podunavlja (Stöllner 1994: 635-636, Abb. 8) i Bratislave prema slučajnome nalazu (Harmadyová 2016: 103, Abb. 1-2). Ovaj tip fibula po broju kuglica razlikuje se od štajerske varijante fibula tipa 6 .

Fibule tipa 6a pojavljuju se u štajerskoj i koruškoj halštatskoj nošnji te na prostoru svetolucijske skupine gdje su karakteristične za Sv. Lucija Ic stupanj (Teržan, Trampuž 1973: 422-427, sl. 2: 1; 3: 1-2). B. Teržan drži da su fibule tipa $6 a$ starije u Štajerskoj u odnosu na fibule u svetolucijskoj skupini (Teržan 1990: 98).

Brončane dvopetljaste lučne fibule s čvorovima na luku pojavljuju se u Pokuplju i u Dolenjskoj. Vrlo sličan nalaz fibuli iz Sotina je primjerak iz tumula u Ozlju koji potječe iz starih iskopavanja Š. Ljubića (Balen-Letunić 1981: 19, T. 4: 9) kao i primjerak iz tumula I/groba 19 na položaju Grm kod Podzemelja (Barth 1969: 113, T. XIV: 8).' Zanimljiv je nalaz luka takve fibule u tumulu II, grobu 17 na Kapiteljskoj njivi u Novom mestu koja ne može biti pobliže pripisana određenoj varijanti, budući da nije sačuvana nožica. U spomenutome grobu pojavljuje se zajedno s čunjastom fibulom, zatim fibulom s dva dugmeta na luku te dvopetljastom lučnom fibulom s nožicom u obliku beotskoga štita koja je bila položena posebno, dok su ostale fibule bio položene zajedno sa strane tijela pokojnika, što bi ukazivalo kako vjerojatno nisu bile dio nošnje pokojnika. Ovaj grob je datiran u StičnaNovo Mesto I horizont (Križ 1997: 16, 43, T. 12). Dvopetljasta lučna fibula s čvorovima na luku pojavljuje se i u grobu 52 tumula 1 (Križ et al. 2009: 6.1, 40). Iz Magdalenske gore poznat je nalaz takve fibule u grobu s jednim od najstarijih prikaza situlske umjetnosti, što ukazuje na donju granicu

1 Na području istočne Dolenjska, Bele Krajine i Žumberka pojavljuje se sličan tip bimetalnih fibula sa željeznom jezgrom, nožicom i iglom (Parzinger 1989: T. 16: 1-2; 36: 1; 38: 1, 23; Grahek 2004: 138-140, sl. 31; Škoberne, Bugar 2017: 86-87). Tu se radi o sličnoj varijanti u izvedbi luka, ali različitoj željeznoj nožici i drugačijem broju čvorova na luku.
19: 6; 91: 14). The appearance of knobbed bow fibulae of this type was also pointed out by M. Egg in the Podzemelj 2 phase (Egg, Kramer 2016: 210). In Carinthia, these fibulae appear in greater numbers in the Frög cemetery (Tomedi 2002: 174), where they are associated with workshops in Carinthia, Upper Carniola and the River Soča Valley, and Upper Styria, while other cases are related with Upper and Lower Austria, Transdanubia, and Styria (Tomedi 2002: 174, PI. 1B: 1; 116: 1-2). The variant appearing in the area of Pannonia, singled out by S. Gabrovec as type $6 \mathrm{a}$, differs from the fibulae of the Sveta Lucija group, primarily in the shape of the foot. Its importance as a determinant for defining variants has also been confirmed by G. Tomedi (Tomedi 2002: 173), who believes that it is impossible to clearly separate the older and younger types of bronze fibulae with spheres on the bow, and he agrees with Gabrovec on the dating of the development of double loop fibulae in the Podzemelj phase (Tomedi 2002: 173). A variant of the fibula from Sveta Lucija includes an incised decoration between the bow knobs, which also applies to the fibula variant from the area of Styria. After the typology of B. E. Glunz, it is type C, which she dated at the Hallstatt cemetery on the basis of the find from Magdalenska gora, and which was dated by S. Gabrovec as being older than $600 \mathrm{BC}$, i.e. to the $\mathrm{Ha}$ C2 period (Glunz 1997: 46-47, Map 5). B. E. Glunz also believes that there is no chronological difference between single loop and double loop knobbed bow fibulae (Glunz 1997: 46). It should be mentioned that the appearance of double loop knobbed bow fibulae can be followed as far as the middle Danube Basin (Stöllner 1994: 635-636, Fig. 8) and Bratislava on the basis of a chance find (Harmadyová 2016: 103, Figs. $1-2)$. The number of spheres differentiates this type of fibulae from the Styrian fibula variant of type $6 a$.

Fibulae of type 6a appear in the Styrian and Carinthian Hallstatt costume and on the territory of the Sveta Lucija group, where they are characteristic of the Sveta Lucija Ic phase (Teržan, Trampuž 1973: 422-427, Fig. 2: 1; 3: 1-2). B. Teržan believes that the type 6a fibulae in Styria are older than the Sveta Lucija group fibulae (Teržan 1990: 98).

Bronze double loop knobbed bow fibulae appear in the River Kupa Valley and in Lower Carniola. A find that is very similar to the Sotin fibula is the item from the Ozalj tumulus, originating from the old excavations of Š. Ljubić (Balen-Letunić 1981: 19, PI. 4: 9), and the item from tumulus I/grave 19 at the Grm site near Podzemelj (Barth 1969: 113, PI. XIV: 8). ${ }^{1}$ There is an interesting find of the bow of such a fibula in tumulus II, grave 17, on Kapiteljska njiva in Novo Mesto, which cannot be attributed in more detail to a particular variant, since the foot has not been preserved. In the mentioned grave, it appears together with a cone-shaped fibula, a fibula with two buttons on the bow, and a double loop fibula with the foot shaped like a Boeotian shield, which used to be laid separately, while other fibulae were laid together next to the dead body, which indicates they probably did not belong to the person's costume. This grave was dated to the Stična-Novo Mesto I horizon (Križ 1997: 16, 43, PI. 12). A double loop knobbed bow fibula also appears in grave 52 of tumulus 1 (Križ et al. 2009: 6.1, 40). A fibula of this kind was found in Magdalenska gora, inside a grave that con-

1 In the areas of southern Lower Carniola, Bela Krajina, and Žumberak, there is a similar type of bimetal fibulae with an iron core, foot, and pin (Parzinger 1989: P1. 16: 1-2; 36: 1; 38: 1, 23; Grahek 2004: 138-140, Fig. 31; Škoberne, Bugar 2017: 86-87). This variant has a similar bow, but a different iron foot, and a different number of bow knots. 


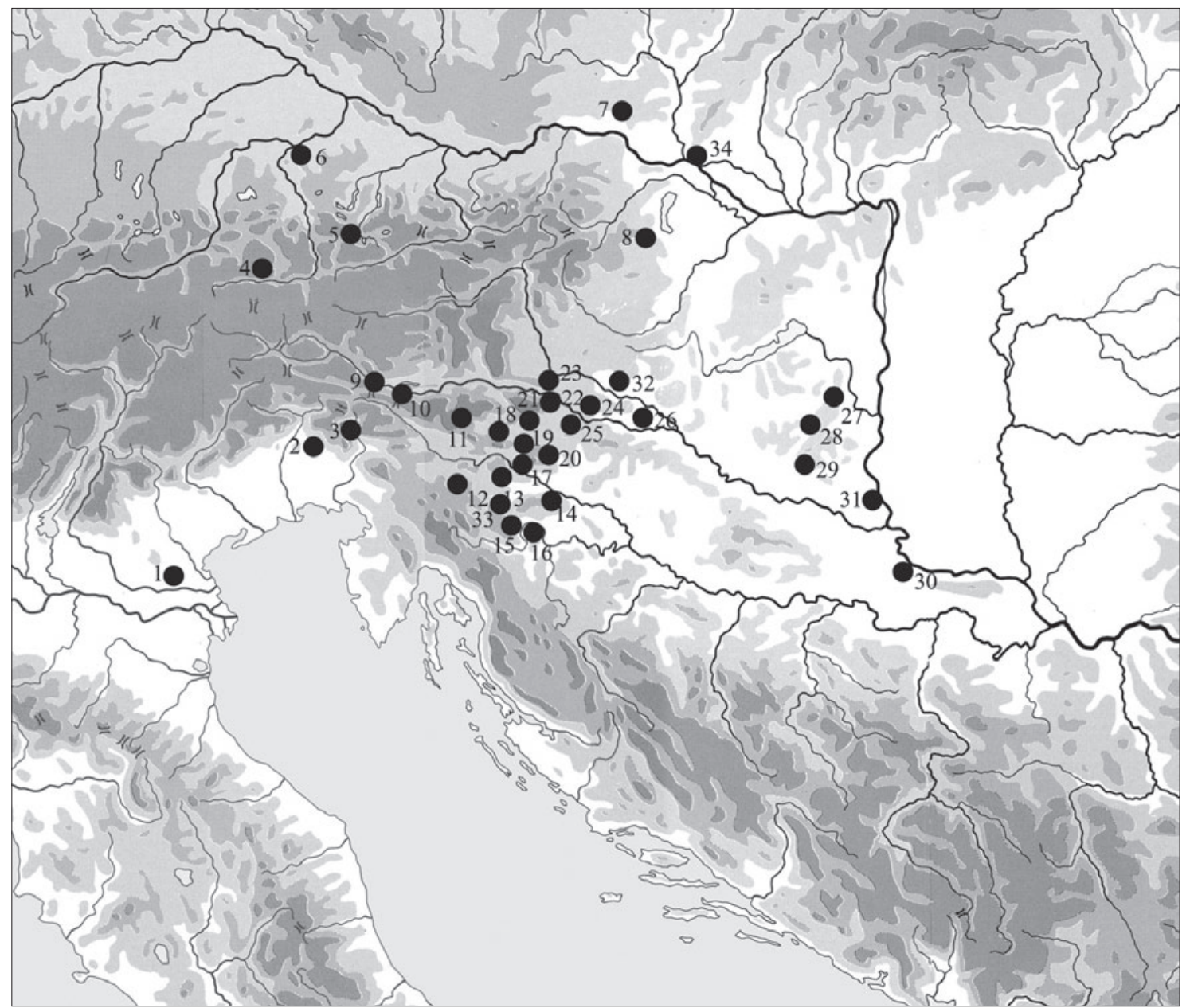

SI. 6 Rasprostranjenost dvopetljastih lučnih fibula tipa 6a (dopunjeno prema: Teržan 1990: karta 10) 1 Este; 2 Cividale; 3 Most na Soči; 4 Uttendorf; 5 Hallstatt; 6 Gilgenberg; 7 Maiersch; 8 Sopron; 9 Villach; 10 Frög; 11 Šentjanž; 12 Magdalenska gora; 13 Šmarjeta; 14 Malence; 15 Podzemelj; 16 Ozalj; 17 Libna; 18 Griže; 19 Vranje; 20 Bistrica ob Sutli; 21 Rifnik; 22 Ruše; 23 Kleinklein; 24 Ptuj; 25 Ptujska gora; 26 Goričan; 27 Nak; 28 Nagyberki Szalacska; 29 Szentlörinc; 30 Sotin; 31 Batina; 32 Nova Tabla; 33 Novo Mesto; 34 Bratislava

Fig. 6 Distribution of double loop bow fibulae of type 6 a (updated after: Teržan 1990: Map 10)

1 Este; 2 Cividale; 3 Most na Soči; 4 Uttendorf; 5 Hallstatt; 6 Gilgenberg; 7 Maiersch; 8 Sopron; 9 Villach; 10 Frög; 11 Šentjanž; 12 Magdalenska gora; 13 Šmarjeta; 14 Malence; 15 Podzemelj; 16 Ozalj; 17 Libna; 18 Griže; 19 Vranje; 20 Bistrica ob Sutli; 21 Rifnik; 22 Ruše; 23 Kleinklein; 24 Ptuj; 25 Ptujska gora; 26 Goričan; 27 Nak; 28 Nagyberki Szalacska; 29 Szentlörinc; 30 Sotin; 31 Batina; 32 Nova Tabla; 33 Novo Mesto; 34 Bratislava

pojave ovih fibula u Stična-Novo Mesto stupanj, a čemu u prilog ide i nalaz iz Novog Mesta, tumul II/17 (Tecco-Hvala 2012: 205-207). S. Gabrovec je naglasio različitu razvojnu dinamiku dvopetljastih fibula s čvorovima na luku na području Dolenjske, što objašnjava veći broj tipova i varijanti (Gabrovec 1970: 37).

Tip fibule koji je pronađen u grobu 1 u Sotinu može se, na osnovi navedenih usporedbi, datirati u Illb horizont prema C. Metzner-Nebelsick (2002: Abb. 184), odnosno u Ha C1b stupanj, što odgovara kraju 8. i prvoj polovici 7. st. pr. Kr. Fibula iz Sotina, prema elementima koji su zamijećeni, najvjerojatnije pripada štajerskome tipu brončanih dvopetljastih lučnih fibula tipa 6a s nekim regionalnim karakteristikama. To se odnosi na tip nožice kakva je zabilježena na fibuli iz Naka u Transdanubiji, a slična je obliku nožice fibule tained one of the earliest examples of situla art, pointing to the lower limit of the appearance of these fibulae in the Stična-Novo Mesto phase, as supported by the find from Novo Mesto, tumulus II/17 (Tecco-Hvala 2012: 205-207). S. Gabrovec emphasized the different pace of development of double loop knobbed bow fibulae in the area of Lower Carniola, accounting for the large number of types and variants (Gabrovec 1970: 37).

On the basis of these parallels, the fibula type found in grave 1 in Sotin can be dated to horizon Illb after C. MetznerNebelsick (2002: Fig. 184), i.e. to phase $\mathrm{Ha} \mathrm{C1b}$, which is equivalent to the end of the $8^{\text {th }}$ and the first half of the $7^{\text {th }}$ cent. $B C$. Considering its elements, the Sotin fibula most probably belongs to the Styrian type of bronze double loop bow fibulae of type 6a with regional characteristics. This applies to the type of foot identified for the fibula from Nak in 
u tumulu 227/1976 u Sopronu (Patek 1983: 144, Abb. 20: 1) gdje je i ukras na nožici istovjetan ukrasu zabilježenome na fibuli u Sotinu. Zanimljiv je spoj luka fibule s iglom pomoću zakovica kakav je zabilježen na primjercima fibula s čvorovima na luku iz Rifnika (Teržan 1990: sl. 20: 4), Nove Table (Guštin et al. 2017: 437, sl. 1353-1354), iz Batine (Márton 1913: T. VI: 34, 38) ili na dvopetljastoj lučnoj fibula iz Dalja (Vinski, Vinski-Gasparini 1962: sl. 76). Zanimljivo je istaknuti kako je nalaz iz groba u Sotinu zasad najjugoistočniji nalaz ovoga tipa fibule (sl. 6).

\section{DVOPETLJASTE LUČNE FIBULE $S$ ČVOROVIMA NA LUKU NA PROSTORU DALJSKE GRUPE}

Fibule imaju značajno mjesto u ženskoj nošnji osobito tijekom željeznoga doba kada se pojavljuje sve veći broj varijanti i inačica. Na području Podunavlja fibule su prvi puta sintezno predstavili Zdenko i Ksenija Vinski u antologijskome radu O utjecajima istočno-alpske halštatske kulture i balkanske ilirske kulture na slavonsko-srijemsko Podunavlje, u časopisu Arheološki radovi i rasprave II, Zagreb 1962. U tome radu predstavljene su fibule starijega željeznog doba s lokaliteta u slavonsko-srijemskome Podunavlju kroz čitavo trajanje starijega željeznog doba. Radi se o nalazima koji se čuvaju u Arheološkome muzeju u Zagrebu. Mnogi predstavljeni tipovi pripadaju dvopetljastim lučnim fibulama koje je kasnije sintezno obradio S. Gabrovec (1970), pri čemu je na kartama rasprostranjenosti bio zastupljen i prostor Podunavlja. Kasnije je sintezni pregled fibula starijega željeznog doba za područje Podunavlja predstavila C. MetznerNebelsick, uključivši i nalaze iz drugih europskih muzeja (Metzner-Nebelsick 2002: 411-426, Abb. 184). Na prostoru Podunavlja preklapaju se zone rasprostranjenosti nekoliko tipova fibula koje su rasprostranjene na širem prostoru Europe u vrijeme starijega željeznog doba (v. Schnurbein 2009: Abb. 203; Teržan 2000: 40-42; 2009: Abb. 15). Zajednice na jugu Karpatske kotline početkom željeznoga doba bile su vrlo pomodne, što se može pratiti na primjeru dvopetljastih fibula s čvorovima na luku. Već je S. Gabrovec uočio dva tipa (5 i 6) ovakvih fibula. Tip 5 podijelio je na tri, a tip 6 na čak pet varijanti (Gabrovec 1970: 27-29, Karte VIII-IX). Rasprostranjenost pojedinih varijanti fibula tipa 5 i 6 pokazuje kako se mogu razlikovati jugoistočnoalpski, podunavski i balkanski tipovi čiji se razvoj može pratiti tijekom 8. st. pr. Kr. Jugoistočnoalpske varijante (Ozalj, nalaz iz tumula; Goričan tumul XX; Sotin grob 1) mogu se pratiti na prostoru čitave sjeverne Hrvatske, dok su podunavske varijante - tip 5b i tip 5c po S. Gabrovcu - prisutne u kosturnim grobovima bosutske zajednice na području zapadnoga Srijema (Vukovar grob 269; Šarengrad grob 1) (Vinski, Vinski-Gasparini 1962: 270-271, T. III: 47; V: 62-63; Vinski-Gasparini 1973: 164, T. 125: 2; Balen-Letunić 2004: 17, 19-20, T. 5: 6-7).

R. Vasić među fibulama podunavskoga tipa razlikuje nekoliko varijanti prema broju čvorova na luku. Fibule rasprostranjene u Srijemu, Bačkoj i istočnoj Slavoniji te u sjeverozapadnoj Bugarskoj imaju četiri čvora na luku i na kraju pločice (Vasić 1999: 62, T. 31: 383-384). Na fibuli iz Popina-
Transdanubia, and it is similar to the shape of the foot of the fibula in tumulus 227/1976 in Sopron (Patek 1983: 144, Fig. 20: 1), where the foot decoration is identical to the decoration recorded for the Sotin fibula. An interesting way of fastening the bow with the pin by means of studs has been recorded for some knobbed bow fibulae from Rifnik (Teržan 1990: Fig. 20: 4), Nova Tabla (Guštin et al. 2017: 437, Figs. 1353-1354), Batina (Márton 1913: PI. VI: 34, 38), and the double loop bow fibula from Dalj (Vinski, Vinski-Gasparini 1962: Fig. 76). Interestingly, the find from the grave in Sotin marks the extent of this fibula type to the south-east (Fig. 6).

\section{DOUBLE LOOP KNOBBED BOW FIBULAE IN THE AREA OF THE DALJ GROUP}

Fibulae have an important role in female costume, especially during the Iron Age, when a growing number of variants appeared. For the Danube Basin, the first synthetic presentation of fibulae was made by Zdenko and Ksenija Vinski in their landmark paper On the influences of the eastern Alpine Hallstatt culture and the Illyrian culture of the Balkans on the Danube Basin in Slavonia and Syrmia, published by the magazine Arheološki radovi i rasprave II, Zagreb 1962. That paper presented Early Iron Age fibulae from the sites in the Danube Basin in Slavonia and Syrmia throughout the Early Iron Age. These finds are kept by the Archaeological Museum in Zagreb. Many presented types belong to double loop bow fibulae, which were the subject of a subsequent synthetic analysis of S. Gabrovec (1970), whose distribution maps included the Danube Basin. A later synthetic analysis of Late Iron Age fibulae in the Danube Basin was presented by C. Metzner-Nebelsick, who included finds from other European museums (Metzner-Nebelsick 2002: 411-426, Fig. 184). The Danube Basin is the area of overlapping distribution zones of several fibula types that were spread over a wide area of Europe during the Early Iron Age (v. Schnurbein 2009: Fig. 203; Teržan 2000: 40-42; 2009: Fig. 15). The southern Carpathian Basin communities at the beginning of the Iron Age were very fashion-conscious, which can be seen from the example of double loop knobbed bow fibulae. S. Gabrovec already identified two types (5 and 6) of these fibulae. He divided type 5 into three variants and type 6 into as many as five variants (Gabrovec 1970: 27-29, Maps VIII-IX). The distribution of particular variants of fibulae of types 5 and 6 shows that we can distinguish between south-eastern Alpine, Danube, and Balkan types, with a development that can be followed throughout the $8^{\text {th }}$ centu. BC. The south-eastern Alpine variants (Ozalj tumulus find; Goričan tumulus XX; Sotin grave 1) can be followed on the entire territory of northern Croatia, while the Danube variants - type 5b and type $5 \mathrm{c}$ after S. Gabrovec - were found in skeleton graves of the Bosut community in the area of western Syrmia (Vukovar grave 269; Šarengrad grave 1) (Vinski, Vinski-Gasparini 1962: 270-271, PI. III: 47; V: 62-63; Vinski-Gasparini 1973: 164, PI. 125: 2; Balen-Letunić 2004: 17, 19-20, PI. 5: 6-7).

Among the Danube type fibulae, R. Vasić distinguishes several variants depending on the number of knobs on the bow. The fibulae found in Syrmia, Bačka and eastern Slavonia, and north-western Bulgaria, have four knobs on the bow and at the end of the plate (Vasić 1999: 62, PI. 31: 383384). Analysing a fibula from Popinci, R. Vasić determined 
ca R. Vasić uočio je kako se radi o varijanti između fibule s čvorovima na luku i fibule s narebrenim lukom (Vasić 1999: 62, T. 31: 391), što ukazuje na lokalni razvoj ovih bimetalnih fibula. R. Vasić fibule ovoga tipa datira u I. horizont željeznoga doba na području Srbije, što odgovara 8. st. pr. Kr. (Vasić 1977: 9). Više varijanti fibula s čvorovima na luku izdvojeno je i na području Bugarske - tipovi BI 1 , $\delta$ i tip BII $1 a, \beta, \gamma, \delta$ koji se datiraju u 8. -7. st. pr. Kr. (Gergova 1987: 37-38, 44-46, T. 8: 104-112; 13; 14: 174-177), a bile su rasprostranjene i na prostoru južne i zapadne Rumunjske (Oltenija i Transilvanija) tijekom Ha C stupnja (Bader 1983: 91-92, T. 31: 241-250).

Intrigantne su zone utjecaja pretpostavljene kao impuls za razvoj fibula koje su obilježile nošnju na širem prostoru južne Panonije. Nije još posve jasno porijeklo fibule s čvorovima na luku i željeznom jezgrom (tzv. vački tip). Na jugoistočnoalpskome prostoru pojavljuje se pravi vački tip fibule s osam i više čvorova na luku, dok su fibule s do četiri čvora na luku (panonska varijanta vačkoga tipa) uglavnom rasprostranjene na prostoru donjega Podunavlja te istočnoga Balkana (Gabrovec 1976: 596-597, Abb. 7). Primjerci iz Ljubljane s 5 i 6 čvorova su međuvrsta između panonske i vačke varijante (Gabrovec 1976: 596-597). Izuzetno je zanimljiva nožica fibula vačkoga tipa koja se u različitim varijantama susreće na istočnome području (Podunavlje, istočni Balkan). Nožica je visoka, pravokutna, zaobljena, simetričnoga oblika. Zanimljivo je da polumjesečaste fibule i fibule s čvorovima na luku, kakve su poznate iz svetolucijske grupe, ne poznaju takav oblik nožice (Gabrovec 1976: 597). Važno je napomenuti kako niti u Panoniji nema prethodnika ovakvim nožicama na fibulama. Jedan od argumenata za ishodište fibula na jugoistočnoalpskome prostoru nalazi se u bimetalnosti fibula koja je najranije zabilježena na lučnoj fibuli iz Jurke vasi (Gabrovec 1976: 597). S. Gabrovec ostavlja otvorenu i mogućnost da je ishodište vačke fibule na području ljubljanske grupe te da je pojava njezine inačice $u$ Podunavlju kulturni utjecaj iz jugoistočnoalpskoga kruga (Gabrovec 1976: 597). Drugačije mišljenje zastupa R. Vasić koji misli da fibule u Podunavlju svoj autohtoni razvoj duguju impulsu iz Grčke i Male Azije gdje su česte fibule s čvorovima na luku (Vasić 1995: 361). S obzirom na dataciju S. Gabrovca ovih fibula u kraj 8. st. pr. Kr. u Dolenjskoj te ističući dataciju u sredinu 8. st. u Grčkoj, R. Vasić pokušava naglasiti jugoistočni impuls u nastanku podunavskih varijanti fibula s čvorovima na luku (varijanta 5b prema S. Gabrovcu) (Vasić 1995: 361). Neosporni je jugoistočni impuls u nastanku ove vrste fibula na prostoru donjega Podunavlja, dok je istovremeno tekao neovisan razvoj takvih fibula na području jugoistočnih Alpi. To je dokazala B. Teržan istovremenošću štajerskih primjeraka fibula tipa 6 a i $6 \mathrm{~d}$ prema S. Gabrovcu i njihovom datacijom u 8. st. pr. Kr., odnosno u I. horizont grobova željeznoga doba u Štajerskoj (Teržan 1990: 98, karta 10). ${ }^{2}$ Ishodište razvoja ideje dvopetljastih fibula (Dörer 2008) i fibula s čvorovima na luku u literaturi posljednjih desetljeća se stavlja na istočni prostor Balkana (Teržan 2009). Prostor daljske grupe označen je kao područje na kojem se,

2 Posljednja publicirana karta na kojoj su kartirane fibule ovoga tipa (Harmadyová 2016) nije obuhvatila kartu B. Teržan (1990: karta 10) na kojoj su detaljno kartirani ovi tipovi fibula za jugoistočnoalpski prostor. that it was a variant between the knobbed bow fibula and the ribbed bow fibula (Vasić 1999: 62, PI. 31: 391), indicating a local development of these bimetal fibulae. R. Vasić dated this type of fibula to horizon I of the Iron Age in Serbia, which is the $8^{\text {th }}$ cent. BC (Vasić 1977: 9). Also, several variants of knobbed bow fibulae have been singled out on the territory of Bulgaria - types BI $1 \gamma, \delta$ and type BII $1 a, \beta, \gamma, \delta$, which have been dated to the $8^{\text {th }}$ and $7^{\text {th }}$ cent. BC (Gergova 1987: 37-38, 44-46, PI. 8: 104-112; 13; 14: 174-177) and they were also widespread in the areas of southern and western Romania (Oltenia and Transylvania) in phase Ha C (Bader 1983: 91-92, PI. 31: 241-250).

Intriguing zones of influence have been proposed as the impulse for the development of the fibulae that characterised the costume in the wide area of southern Pannonia. The origin of the iron core knobbed bow fibula (the "Vače type") is still not quite clear. The south-eastern Alpine area had the real Vače type fibula with eight or more knobs on the bow, while the fibulae with four or less knobs on the bow (the Pannonian variant of the Vače type) were mostly distributed in the area of the lower Danube Basin and eastern Balkans (Gabrovec 1976: 596-597, Fig. 7). The examples with 5 and 6 knobs from Ljubljana are an inter-type between the Pannonian and the Vače variants (Gabrovec 1976: 596-597). The exceptionally interesting foot of the Vače type fibula has been recorded in different variants in the eastern area (Danube Basin, eastern Balkans). The foot is tall, rectangular, rounded and symmetrical. Curiously, the crescent fibulae and knobbed bow fibulae, which are known from the Sveta Lucija group, do not include this form of the foot (Gabrovec 1976: 597). Moreover, it should be noted that Pannonia has no precedents for this foot of the fibula. One of the arguments for the south-eastern Alpine region as the origin of the fibulae is their bimetal nature, the earliest example being the bow fibula from Jurka vas (Gabrovec 1976: 597). S. Gabrovec does not exclude the possibility that the Vače fibula originated in the Ljubljana group area, and that the appearance of its variant in the Danube Basin was a cultural influence from the south-eastern Alpine sphere (Gabrovec 1976: 597). A different opinion is provided by R. Vasić, who believes that the Danube Basin fibulae owe their autochthonous development to an impulse from Greece and Asia Minor, where knobbed bow fibulae are frequent (Vasić 1995: 361). Considering that S. Gabrovec dated these fibulae to the end of the $8^{\text {th }}$ cent. BC in Lower Carniola, and pointing to the mid- $8^{\text {th }}$ cent. BC dating in Greece, R. Vasić tries to emphasize the south-eastern impulse in the appearance of the Danube Basin variants of knobbed bow fibulae (variant 5b after S. Gabrovec) (Vasić 1995: 361). There is an undeniable south-eastern impulse in the appearance of this fibula type in the lower Danube Basin; at the same time, these fibulae developed independently in the south-eastern Alpine area. B. Teržan proved it by showing that the Styrian fibulae of types $6 \mathrm{a}$ and $6 \mathrm{~d}$ after S. Gabrovec were simultaneous and dated to the $8^{\text {th }}$ cent. BC, i.e. horizon I of Iron Age graves in Styria (Teržan 1990: 98, Map 10). ${ }^{2}$ The source of the development of the idea of double loop fibulae (Dörer 2008)

2 The last published map showing the fibulae of this type (Harmadyová 2016) did not include the map of B. Teržan (1990: Map 10), where these types of fibulae were mapped in detail for the south-eastern Alpine sphere. 
prema nalazima fibula sa čvorovima na luku, miješaju utjecaji zapadnoga alpskog, istočnoga donjepodunavskog i južnoga balkanskog kruga (Teržan 2009: Abb. 15).

Nalazi fibula u grobovima u Batini, Vukovaru (VinskiGasparini 1973: 163-163, T. 123: 10; 124: 7; 125: 2, 6), Doroslovu (Trajković 2008: grob 58, 4; grob 141, 14), Sotinu i Šarengradu (Vinski, Vinski-Gasparini 1962: 271, T. V: 62-63; Balen-Letunić 2004: 17, 19-20, T. 5: 6-7) možda pružaju korektiv za finiju kronološku podjelu. Nalazi bimetalnih fibula u zatvorenim kontekstima grobova 269 u Vukovaru (VinskiGasparini 1973: T. 125: 1-4) i rekonstruiranome grobu $1 \mathrm{u}$ Šarengradu (Balen-Letunić 2004: 17, 19-20, T. 5: 6-7) jasno su datirani u Illa horizont daljske grupe (Metzner-Nebelsick 2002: 415). Pojava brončanih fibula s čvorovima na luku datirana je u horizonte IIla i Illb prema C. Metzner-Nebelsick. Novija istraživanja ukazuju kako su fibule podunavske varijante (tip 5b i tip 5c) pronađene u grobovima koji se, prema načinu pokopavanja ili keramičkim prilozima, mogu povezati s bosutskom grupom (Popović, Vukmanović 1998: 79, PI. 18: 13; Balen-Letunić 2004: 17, 19-20, T. 5: 6-7). S druge strane, fibule tipa $6 a$ nalaze se u grobovima koji pokazuju panonsku tradiciju u paljevinskome načinu pokopa, zatim keramičkim prilozima i konceptu pogrebnih običaja, kao npr. u grobu u Sotinu i najbližim paralelama (tumul 224/1976 u Sopronu). Datacija bimetalnih fibula ranije u Ha C1a stupanj prema Ch. Pareu (1998: 404-405, Tab. 5) je opravdana na prostoru Podunavlja, što se poklapa i s datacijom R. Vasića u početni horizont željeznoga doba (Vasić 1977: 9; 1999: 59), dok se brončane varijante fibula s čvorovima na luku jugoistočnoalpskih varijanti datiraju u Ha C1b stupanj. Šira datacija brončanih fibula s čvorovima na luku od početnoga horizonta željeznoga doba u Štajerskoj do u Ha C2 stupanj, odnosno do Stična horizonta prema nalazu iz Magdalenske gore (Gabrovec 1970: 41, T. 20: 8; 1987: 52) ukazuje na dužu upotrebu nakita s čvorovima, što je vidljivo i u ogrlicama s čvorovima na luku koje su u upotrebi do kasnoga Ha D stupnja (Gabrovec 1987: 52, sl. 3: 14; Teržan 1990: 98-99, karta 11; Vasić 2010: 46, T. 34: 225; 44). Nalazi ogrlica s čvorovima na luku u Srijemskoj Rači (Vinski, Vinski-Gasparini 1962: 272, T. V: 67; Vasić 2010: 46, T. 34: 225; 44) i Nuštru (Ložnjak Dizdar 2019: 248-249, PI. 1), za koje nije poznat kontekst nalaza, ali koje svojim tipološkim karakteristikama omogućavaju usku dataciju u početni horizont željeznoga doba (Vasić 1977: 9-12), pokazuju kako su torkvesi s čvorovima na luku i fibule raznih varijanti nakit koji se nosi početkom željeznoga doba na prostoru Podunavlja.

Fibula iz groba 1 u Sotinu može se datirati prema najsličnijim usporedbama (Rifnik, Batina, Sopron) te povezati sa štajerskim tipovima fibula, odnosno panonskim tipovima kako ih naziva G. Tomedi, te datirati u Ha C1b stupanj prema Ch. Pareu (Patek 1982: 13, Tab. 1; Teržan 1990: 98; MetznerNebelsick 2002: 415), s mogućnošću da su se ovakve fibule nosile i ranije tijekom Ha C1a stupnja prema zabilježenim konteksima, npr. u grobu 1903/14 u Rifniku (Teržan 1990: 98). Primjerak fibule iz Sotina svojim oblikom nožice kao i načinu kako je igla pričvršćena za luk fibule dvjema zakovicama, pokazuje sličnosti s panonskim varijantama koje se pojavljuju od Štajerske, južne Transdanubije do Sotina and knotted bow fibulae in the papers in recent decades has been identified with the eastern Balkan sphere (Teržan 2009). The Dalj group area has been identified as a meeting place of the influences of the western Alpine, eastern lower Danube, and southern Balkans spheres, as shown by the finds of knotted bow fibulae (Teržan 2009: Fig. 15).

The fibulae found in graves in Batina, Vukovar (VinskiGasparini 1973: 163-163, PI. 123: 10; 124: 7; 125: 2, 6), Doroslovo (Trajković 2008: grave 58, 4; grave 141, 14), Sotin, and Šarengrad (Vinski, Vinski-Gasparini 1962: 271, PI. V: 62-63; Balen-Letunić 2004: 17, 19-20, PI. 5: 6-7), could be a corrective for a more nuanced chronological classification. The finds of bimetal fibulae in the closed contexts of graves 269 in Vukovar (Vinski-Gasparini 1973: PI. 125: 1-4) and the reconstructed grave 1 in Šarengrad (Balen-Letunić 2004: 17, 19-20, PI. 5: 6-7) are clearly dated to horizon Illa of the Dalj group (Metzner-Nebelsick 2002: 415). The appearance of bronze knotted bow fibulae was dated to horizons IIla and IIIb after C. Metzner-Nebelsick. Recent research indicates that the fibulae of the Danube variant (type 5b and type $5 c$ ) have been found in graves that can be associated with the Bosut group on the basis of burial methods or ceramic goods (Popović, Vukmanović 1998: 79, PI. 18: 13; Balen-Letunić 2004: 17, 19-20, PI. 5: 6-7). On the other hand, type 6a fibulae have been found in graves reflecting the Pannonian tradition in their cremation burial method, their ceramic goods, and their concept of funerary rites, such as e.g. the Sotin grave and its closest parallels (tumulus 224/1976 in Sopron). The earlier dating of bimetal fibulae to phase $\mathrm{Ha}$ C1a after Ch. Pare (1998: 404-405, Tab. 5) is justified for the Danube Basin, which matches the dating of R. Vasić to the initial horizon of the Iron Age (Vasić 1977: 9; 1999: 59), while the bronze variants of knobbed bow fibulae of the southeastern Alpine variants are dated to phase $\mathrm{HaC} \mathrm{C} b$. The wider dating of bronze knobbed bow fibulae, from the initial horizon of the Iron Age in Styria to phase $\mathrm{Ha} \mathrm{C2}$, or to the Stična horizon on the basis of a find from Magdalenska gora (Gabrovec 1970: 41, PI. 20: 8; 1987: 52), indicates a longer use of knobbed jewellery, which can be seen in the knobbed bow necklaces that were in use until the late Ha D phase (Gabrovec 1987: 52, Fig. 3: 14; Teržan 1990: 98-99, Map 11; Vasić 2010: 46, PI. 34: 225; 44). The knobbed bow necklaces found in Srijemska Rača (Vinski, Vinski-Gasparini 1962: 272, PI. V: 67; Vasić 2010: 46, PI. 34: 225; 44) and Nuštar (Ložnjak Dizdar 2019: 248-249, PI. 1) have an unknown context, but their typological characteristics allow for the narrow dating to the initial horizon of the Iron Age (Vasić 1977: 9-12), showing that knobbed bow torcs and different variants of fibulae were worn as jewellery at the beginning of the Iron Age in the Danube Basin.

The fibula from grave 1 in Sotin can be dated on the basis of the most similar parallels (Rifnik, Batina, Sopron) and related to the Styrian types of fibulae, or the Pannonian types as they are called by G. Tomedi, and dated to phase Ha C1b after Ch. Pare (Patek 1982: 13, Tab. 1; Teržan 1990: 98; Metzner-Nebelsick 2002: 415), but it is possible that such fibulae were worn even earlier, in phase $\mathrm{Ha} \mathrm{C1a}$, on the basis of the identified contexts, e.g. in grave 1903/14 in Rifnik (Teržan 1990: 98). The Sotin fibula, with its foot shape and its method of fastening the pin to the bow by means of two studs, shows similarities with the Pannonian variants appea- 
(Teržan 1990: 98, karta 10). Ostaje otvoreno pitanje o kronološkim razlikama ili rasprostranjenosti različitih varijanti istih tipova brončanih fibula s čvorovima na luku na početku starijega željeznog doba u južnome dijelu Karpatske kotline sve dok se neće raspolagati s većim brojem zatvorenih grobnih cjelina s potpunije sačuvanim fibulama s nožicom i cjelovitim lukom, kao i mogućim grobnim cjelinama gdje se pojavljuju zajedno. Upravo područje Podunavlja, gdje se pojavljuje više tipova fibula s čvorovima na luku različitih provenijencija, može biti ključno u rješavanju pitanja kronologije. Duža upotreba na području Dolenjske (Gabrovec 1987: 49; Parzinger 1988: 47) može se pripisati i tradiciji halštatskih zajednica koja je naglašena i prilaganjem starije nošnje u grobove, npr. fibule u grobu u Novom Mestu (Križ 2019: 67, 85-86, sl. 46; 67).

Varijanta brončanih fibula s čvorovima na luku tipa $6 a$ prema tipologiji S. Gabrovca, koja je osobito brojna u Štajerskoj, a pojavljuje se od Ha Cla stupnja i kasnije tijekom $\mathrm{Ha}$ C1b stupnja, rasprostranjena je s manjim lokalnim razlikama (ukrašeni luk i nožica fibule, način spajanja luka i igle fibule) na širem prostoru Panonije, odnosno istočnoga halštatskog kruga sudeći prema primjercima iz tumula 224/1976 u Sopronu (Patek 1982: 13, Tab. 1; 1983: 114, Abb. 20: 1), nalazu iz Naka (Patek 1981: T. 2: 17) i grobu 1 u Sotinu.

\section{IGLA}

13. IGLA (T. 2: 2)

Željezo; dužina: 6,6 cm; promjer: 0,2 cm.

Ulomak željezne igle koja je savijena na kraju.

Institut za arheologiju, PN 41.

Željezna igla pronađena je slomljena u žari među spaIjenim kostima, a mogla je biti dio fibule ili služiti kao neko oruđe, možda igla za kukičanje u svakodnevnome životu. S obzirom da nisu pronađeni ostali masivniji dijelovi neke fibule kojoj bi mogla pripadati, može se uzeti u obzir i ova druga varijanta.

Grob 1 iz Sotina može se prema oblicima lonaca kao i tipu fibule datirati u IIlb keramički horizont lokalne kronologije (Metzner-Nebelsick 2002: 172-175, 415, Abb. 75; 184), što odgovara Ha C1b stupnju, odnosno razdoblju kraja 8. i prve polovice 7. st. pr. Kr.

\section{INTERPRETACIJA GROBA 1 IZ SOTINA TE PITANJE STATUSA POKOJNICE}

Podaci koji su prikupljeni istraživanjem groba 1 te su potom ispitani interdisciplinarnim analizama, uz dokumentirani kontekst te tragove zabilježene na predmetima, omogućavaju rekonstrukciju scenarija pokopa pokojnice i djeteta.

\section{SCENARIJ POKOPA}

Scenarij pokopa u grobu 1 vjerojatno se odvio na slijedeći način. Odrasla ženska osoba u dobi između 20-35 godina i dijete starosti 0,16-0,22 godine bili su zajedno spaljeni na lomači. O bliskoj vezi odrasle žene i djeteta svjedoči zajednička lomača kao i velika žara u kojoj su zajedno sahranjeni. Mali lonac u žari može imati značenje zasebne žare za dijete. ring from Styria and southern Transdanubia to Sotin (Teržan 1990: 98, Map 10). The issue of chronological differences or distribution of different variants of the same types of bronze knobbed bow fibulae at the beginning of the Early Iron Age in the southern Carpathian Basin will remain open until there is a larger number of closed funerary complexes with more fully preserved fibulae with a foot and a whole bow, as well as possible funerary complexes where they appear together. The Danube Basin, containing several types of knobbed bow fibulae of different origins, can be crucial for resolving chronological issues. The longer use in the area of Lower Carniola (Gabrovec 1987: 49; Parzinger 1988: 47) can be attributed to the tradition of Hallstatt communities, which is emphasized by laying older costumes into the graves, e.g. fibulae in the grave in Novo Mesto (Križ 2019: 67, 85-86, Fig. 46; 67).

The variant of knobbed bow fibula of type 6 a after the typology of S. Gabrovec, which is particularly numerous in Styria and appears starting from phase $\mathrm{Ha} \mathrm{Cla}$ and during phase $\mathrm{Ha} \mathrm{C1b}$, is distributed with minor local differences (decorated bow and foot, method of joining bow and pin) in the wider area of Pannonia, or the eastern Hallstatt sphere judging by the items from tumulus 224/1976 in Sopron (Patek 1982: 13, Tab. 1; 1983: 114, Fig. 20: 1), the find from Nak (Patek 1981: PI. 2: 17), and grave 1 in Sotin.

\section{PIN}

\section{PIN (PI. 2: 2)}

Iron; length: $6.6 \mathrm{~cm}$; diameter: $0.2 \mathrm{~cm}$.

A fragment of an iron pin that is twisted at the end.

Institute of Archaeology, SF 41.

A broken iron pin found among the cremated bones in an urn. It could have been part of a fibula or used as a tool, maybe a knitting needle in everyday life. Since there were no other, larger parts of a fibula that the pin would have belonged to, we can take into account the other possibility too.

On the basis of pot shapes and fibula type, grave 1 from Sotin can be dated to ceramic horizon IIlb of the local chronology (Metzner-Nebelsick 2002: 172-175, 415, Fig. 75; 184), matching phase $\mathrm{Ha} \mathrm{C} 1 \mathrm{~b}$, or the period from the end of the $8^{\text {th }}$ cent. to the first half of the $7^{\text {th }}$ cent. BC.

\section{INTERPRETATION OF GRAVE 1 FROM SOTIN AND THE ISSUE OF THE WOMAN'S STATUS}

The data collected during the excavation of grave 1 and examined in interdisciplinary analyses, along with the documented context and the traces recorded on items, make it possible to reconstruct the burial procedure for the woman and child.

\section{BURIAL PROCEDURE}

The burial in grave 1 was probably conducted in the following way. An adult woman aged between 20 and 35 and a child aged between 0.16 and 0.22 were burned together on the pyre. The close relationship of the adult woman and the child is confirmed by the shared pyre and the large urn where they were buried together. The small pot inside the urn may signify a separate urn for the child. In the 
Tijekom kasnoga brončanog doba djeca su od najranije dobi imala zasebnu žaru (Ložnjak Dizdar, Rajić Šikanjić u tisku).

Nakon što je žara položena u grob sa spaljenim ostacima pokojnika i slomljenim dijelovima nošnje koja nije bila izložena vatri, priloženi su dijelovi keramičkoga servisa sa popudbinom u piću i jelu. Najprije su položeni veći lonci s tekućinom, sudeći prema nalazima kantharosa u većem loncu (6) i šalice u jednome od dva slična lonca. Zatim su stavljene zdjele, jedna na postolju s nepoznatim sadržajem, između žare i lonca (5), te druga zdjela s komadom mesa gornjega dijela hrpta i rebrima mlađe ovce/koze položene između žare i drugih lonaca (4-6). Posude s popudbinom bile su složene istočnije od žare u manjoj grobnoj raci, pri čemu se vodilo računa da su prvo položeni lonci, koji su bili veći zapreminom i vjerojatno još teži napunjeni tekućinom, a nakon njih zdjele s vjerojatno krutim sadržajem. Nakon toga je grobna raka bila zatrpana.

Mogući scenariji pokopa mogu se rekonstruirati prema zabilježenim kontekstima grobne cjeline i tragovima na predmetima priloženima u grobove (Sofaer 2015: 137; Fülöp, Váczi 2016; Nebelsick 2016: 22-28). Ispraćaj pokojnika složeni je emotivni događaj koji se tijekom starijega željeznog doba u Podunavlju odvijao prema pravilima koja se daju uočiti na grobljima s većim brojem istraženih grobova (Trajković 2008: 19). Transformacija tijela spaljivanjem događala se u prvome dijelu pogrebnoga rituala (Nebelsick 2016: 22-28, Fig. 1/1,1), a zatim je slijedila konstrukcija groba s ostacima pokojnika i grobnim inventarom, što je sigurno zahtjevalo raniju organizaciju jela i pića za popudbinu kao i transport do groba. Polaganje žare, spaljenih ostataka pokojnika, a zatim i posuda odvijali su se prema unaprijed određenome planu, što je vidljivo u veličini grobne rake. Grobovi s manjim brojem posuda imaju manju grobnu raku, dok grobovi s većim brojem posuda imaju veću grobnu raku. Grobna raka groba 1 u Sotinu bila je iskopana prema planiranome scenariju. Scenariji i provedba takvih pokopa imali su važnu ulogu u procesu žalovanja i emocijama zajednice koja je ispraćala pokojnike (Sofaer, Stig Sørensen 2013; Sofaer 2015: 145; Nebelsick 2016: 31). Sačuvani tragovi predmeta u grobovima nude mogućnosti za rekonstrukciju dijela toga složenog procesa i tumačenje značenja koje su imali za zajednicu.

\section{NOŠNJA I OSOBNI PREDMETI}

Kompozicija groba koja je postavljena na kraju rituala, a prije zatrpavanja, imala je značenje za završetak jednoga i početak slijedećega ciklusa (v. Gennep 1909; Sofaer 2015: 147). Tragovi prethodnoga života, spaljeni na lomači i/ili uništeni lomljenjem bili su položeni u žaru zajedno s ostacima tijela. Njih se može tumačiti osobnim predmetima pokojnice. Fibula je, sudeći prema veličini, vjerojatno pripadala odrasloj ženi sahranjenoj u žari. Fibule nisu čest prilog u grobovima daljske grupe. Većina fibula može se, na osnovi svojih tipoloških karakteristika, pripisati fibulama koje su se nosile na prostoru istočnoga halštatskog kruga (MetznerNebelsick 2002: 413-426, Abb. 184; 190), dok se rjeđi nalazi fibula mogu povezati s balkanskim krugom (Vinski, VinskiGasparini 1962: sl. 108-112; T. II: 47; V: 62-63; VII: 75-80; VIII:
Late Bronze Age, children had a separate urn even at the earliest age (Ložnjak Dizdar, Rajić Šikanjić, in print).

After the urn was laid in the grave with the cremated remains of the dead and the broken parts of the costume that was not exposed to the fire, the mourners added parts of a ceramic set with food and drinks as departing gifts. They placed larger pots with liquids first, judging by the find of a kantharos in a larger pot (6) and a cup in one of the two similar pots. Then they added bowls. One bowl had unknown contents and stood on a stand between the urn and the pot (5); the other bowl contained a piece of meat from the upper part of the loin and the ribs of a young sheep/ goat placed between the urn and other pots (4-6). The vessels with the departing gifts were placed to the east of the urn, in a small burial pit; it was taken care to start by placing the pots, which had a greater volume and probably were even heavier because of the liquid, and to follow them with bowls, which probably had solid contents. Then the grave pit was covered.

Possible burial procedures can be reconstructed from the identified contexts of the funerary complex and the traces on grave goods (Sofaer 2015: 137; Fülöp, Váczi 2016; Nebelsick 2016: 22-28). The farewell from the deceased is a complex emotional event; in the Danube Basin in the Early Iron Age this event followed some rules, which can be identified in the cemeteries with many explored graves (Trajković 2008: 19). The transformation of bodies by burning took place in the first part of the burial rite (Nebelsick 2016: 22-28, Fig. 1/1,1); it was followed by the construction of the grave with the remains of the dead and the grave inventory, which certainly required the earlier preparation of food and drink as farewell gifts and transport to the grave. The urn, the cremated remains of the dead, and the vessels, were laid according to a predefined plan, which can be seen from the size of the burial pit. Graves with fewer vessels have a smaller burial pit, while graves with more vessels have a larger burial pit. The burial pit of grave 1 in Sotin was dug in accordance with a plan. The procedures and the implementation of such burials had an important role in the process of mourning and the emotions of the community that said farewell to its dead (Sofaer, Stig Sørensen 2013; Sofaer 2015: 145; Nebelsick 2016: 31). The preserved traces of objects in the graves make it possible to reconstruct a part of that complex process and to interpret the meaning it had for the community.

\section{COSTUME AND PERSONAL ITEMS}

The composition of the grave, which was set up at the end of the ritual and before the filling of the pit, meant the end of one cycle and the beginning of another (v. Gennep 1909; Sofaer 2015: 147). Traces of the previous life, burnt on the pyre and/or destroyed by breaking, were laid in the urn together with the bodily remains. They can be interpreted as being the personal items of the buried woman. Considering its size, the fibula probably belonged to the adult woman buried in the urn. Fibulae are not frequent grave goods in the graves of the Dalj group. On the basis of their typological characteristics, most fibulae can be counted among the fibulae worn within the eastern Hallstatt sphere (Metzner-Nebelsick 2002: 413-426, Fig. 184; 190), while there are fewer finds of fibulae that can be associated with the 
55, 58, 60-61; Heilmann 2016: 12-16, Fig. 3; 5; Gavranović 2007: 163-165, Abb. 8). Rjeđe su u grobovima povezanima s pogrebnim ritualom daljske grupe pronađene fibule koje se mogu povezati s podunavskim krugom kao u grobu $75 \mathrm{iz}$ Vukovara Lijeve Bare (Vinski-Gasparini 1973: 163, T. 124: 5-7), koje su uobičajeni prilog u kosturnim grobovima zabilježenima na rubnome prostoru grupe Dalj gdje je njihova zapadna granica rasprostiranja (Balen-Letunić 2004: 17, 19-20, T. 5: 6-7; Vasić 1999: 59, T. 65). Rasprostranjenost fibula tipa $6 a, s$ najjugoistočnijim nalazom iz Sotina, ukazuje kako se na ovome prostoru nalazi istočna granica rasprostranjenosti varijante fibula koja se povezuje sa zapadnopanonskim i jugoistočnoalpskim prostorom.

Fibula je bila slomljena i pomiješana sa spaljenim kostima. Na isti je način bila položena u grob i željezna igla s kukicom. Među spaljenim kostima pronađen je i pršljen manjih dimenzija. Veličina pršljena, koji je manji od uobičajenih koji se pojavljuju u grobovima daljske grupe u Doroslovu (Trajković 2008: grob 6, 5-10, passim) i Batini (Bojčić et al. 2018: 166-167, T. 1: 1), može ukazivati na izradu vrlo finoga prediva na vretenu čiji je zamašnjak bio. Takav pršljen mogao je biti i osobni predmet odrasle osobe, npr. uloga perle na pojasu od organskoga materija. Zbog dimenzija predmeta možda ga se može tumačiti i kao neki dar, prilog ili igračku povezanu s djetetom (Hladiková 2011: 294). Ako je pršljen imao svoju osnovnu namjenu za izradu finoga vunenog prediva, a željezna igla je bila dio alata ili je možda služila za kukičanje, onda se možda može pretpostaviti kako je pokojnica iz groba 1 poznavala umijeća vezana uz predenje i izradu tekstila.

Različiti predmeti vezani za tekstilne djelatnosti uobičajeni su prilog u grobovima istočnoga halštatskog kruga
Balkans sphere (Vinski, Vinski-Gasparini 1962: Figs. 108-112, PI. II: 47; V: 62-63; VII: 75-80; VIII: 55, 58, 60-61; Heilmann 2016: 12-16, Fig. 3; 5; Gavranović 2007: 163-165, Fig. 8). A rarer find in the graves related to the burial rite of the Dalj group, some fibulae can be associated with the Danube sphere, as in the case of grave 75 from Vukovar Lijeva Bara (Vinski-Gasparini 1973: 163, PI. 124: 5-7); they are common grave goods in the skeleton graves recorded on the edge of the Dalj group, at the western extent of their distribution (Balen-Letunić 2004: 17, 19-20, PI. 5: 6-7; Vasić 1999: 59, PI. $65)$. The distribution of the fibulae of type $6 a$, with the extreme south-eastern find from Sotin, indicates that this area is the eastern border of distribution of the fibula variant associated with the western Pannonian and the south-eastern Alpine regions.

The fibula was broken and mixed with the cremated bones. An iron pin with a hook was laid in the grave in the same way. A small spindle-whorl was found among the cremated bones. The size of the spindle-whorl, which is smaller than the ones usually found in the graves of the Dalj group in Doroslovo (Trajković 2008: grave 6, 5-10, passim) and Batina (Bojčić et al. 2018: 166-167, PI. 1: 1), can point to the production of very fine yarn on a loom containing the spindle-whorl. Also, the spindle-whorl could have been a personal item of an adult, such as a bead on an organic belt. Considering its size, it could be interpreted as a gift, a grave good, or a toy related to the child (Hladiková 2011: 294). If the spindle-whorl served its basic purpose for the production of fine wool yarn, and the iron pin belonged to a tool or served for knitting, it might be assumed that the woman from grave 1 was skilled in spinning and the production of textiles.

\section{SOTIN GROB 1}
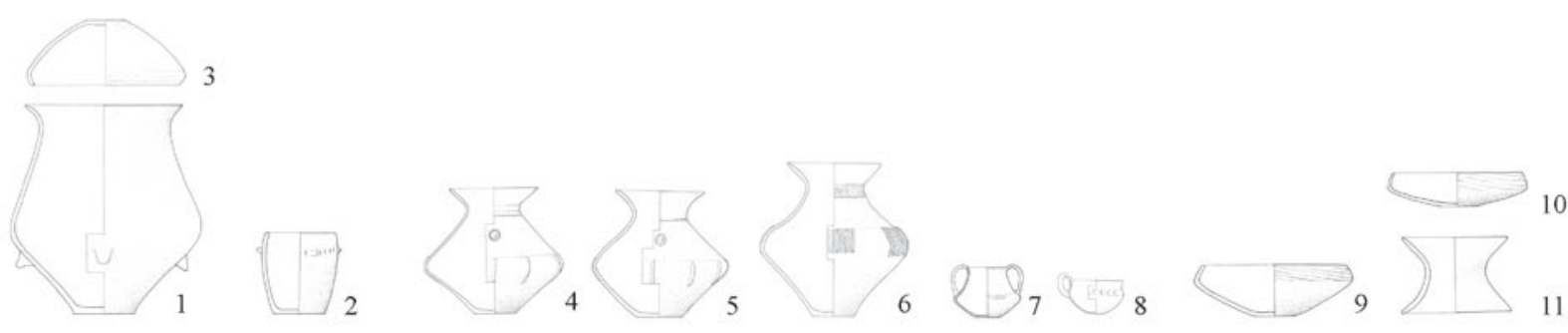

DOROSLOVO GROB 17

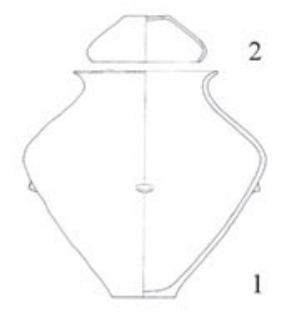

2
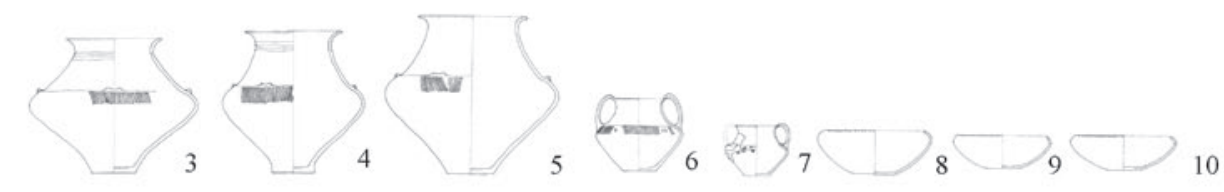

SI. 7 Keramičke posude iz Sotina, grob 1 i Doroslova, grob 17 (prema: Trajković 2008: grob 17)

Fig. 7 Ceramic vessels from Sotin, grave 1, and from Doroslovo, grave 17 (after: Trajković 2008: grave 17) 
(Teržan 1996; Metzner-Nebelsick 2002: 201; Ložnjak Dizdar 2015: 39-40, karta 2) te se povezuju s društvenim statusom ženskih članova zajednice (Teržan 1996: 529; 2004: 222; Eibner-Persy 2001; Grömer 2016: 262-265).

Bliska usporedba grobu 1 iz Sotina bogati je ženski grob 224/1976 iz Soprona u kojem su se, uz veći keramički servis te osobne predmete pokojnice (fibula i nakit), nalazili i dijelovi alata - pršljeni i utezi - za produkciju tekstila (Patek 1983: 145, 148, Abb. 20: 4-5; 23; Teržan 1996: 518). U grobovima 10 i 25 u Novoj Tabli pršljeni su pronađeni uz dvopetljaste lučne fibule tipa 6a i ostale priloge (Guštin et al. 2017: 424, 1288-1289; 436, 1352). Kombinacija fibula tipa 6a u zatvorenim cjelinama s pršljenima ukazuje kako su je nosile žene, a prema antropološkoj analizi spaljenih ostataka iz groba 1 u Sotinu, vidljivo je kako se radi o odrasloj ženi. Prilozi poput pribora za predenje u sličnim grobovima dokazuju kako su te žene posjedovale i znanja koja su im jamčila i određeni status u zajednici, sudeći prema ostalim prilozima u grobovima.

\section{POPUDBINA}

U grobu 1, uz žare i poklopac, bio je priložen keramički servis sastavljen od osam posuda (sl. 7). Običaj prilaganja keramičkih servisa u grobove čest je na kraju kasnoga brončanog doba, a osobito tijekom početnih faza starijega željeznog doba na prostoru srednjega Podunavlja, odnosno istočnoga halštatskog kruga (Nebelsick 1994: 312-315, 357, Abb. 4; 1997: 32; Metzner-Nebelsick 2002: 179-180, Abb. 79-80; Nebelsick 2016: 22-31).

Keramički set u kombinaciji tri lonca s tekućinom i dvije zdjele s hranom ukazuju na običaj prilaganja popudbine za drugi svijet koja je uobičajena na grobljima daljske grupe (Vinski-Gasparini 1983: 609; Metzner-Nebelsick 2002: 179180, Abb. 79-80; Trajković 2008: 19). U tri lonca veće zapremine nalazila se tekućina, što se može zaključiti prema kantharosu i šalici koji su pronađeni u dva lonca. Veličina ovih lonaca kao i kombinacija konteksta s recipijentima za piće koja je vrlo uobičajena u istočnome halštatskom krugu, ukazuje na njihovu statičnu funkciju u ceremoniji ispijanja koja se povezuje s htoničkim dijelom pogrebnih običaja i ritualnom dramom koja se odvijala tijekom pogreba (Nebelsick 2016: 22-23). Ipak, o samoj sadržini lonaca, prije provedenih residio analiza, ne može se pobliže govoriti.

$U$ jednoj zdjeli bili su priloženi i komad vrata s manjim dijelom leđa i gornjih dijelova rebara mlađe koze ili ovce. Nespaljeni komadi mesa uobičajeni su prilog u grobovima već od kasnoga brončanog doba u istočnome dijelu Karpatske kotline i uz tok Dunava (Ložnjak Dizdar, Rajić Šikanjić 2016: 117, Fig. 5). Ovakvi nespaljeni komadi mesa prilagani su u grobove u Doroslovu, gdje je zabilježeno kako su životinjske kosti ovce/koze bile pronađene također u zdjelama, ali i ispod posuda u grobovima (Blažić 2008: 360, 363, tab. 1). Meso od ovce prilagano je i u grobljima Füzesabony, Sirok, Maklár i Dormánd u Potisju (Metzner-Nebelsick 1998: Abb. 7; 10). Zanimljiva parelela prema konceptu popudbine je grob 17 iz Doroslova u kojem je pronađena žara, zatim tri lonca i tri zdjele te dva kantharosa. U žari su pronađeni dijelovi rebara i kralježaka ovce/koze (Trajković 2008: 41-43,
Different items related to textile activities are common grave goods in the graves of the eastern Hallstatt sphere (Teržan 1996; Metzner-Nebelsick 2002: 201; Ložnjak Dizdar 2015: 39-40, Map 2) and are associated with the social status of the female members of the community (Teržan 1996: 529; 2004: 222; Eibner-Persy 2001; Grömer 2016: 262-265).

A close parallel with grave 1 from Sotin is a woman's rich grave 224/1976 from Sopron, which contained not only a large ceramic set and personal items of the woman (a fibula and jewellery), but also tool parts - spindle-whorls and weights - for the production of textiles (Patek 1983: 145, 148, Fig. 20: 4-5; 23; Teržan 1996: 518). In graves 10 and 25 in Nova Tabla, spindle-whorls were found together with double loop bow fibulae of type $6 a$ and other grave goods (Guštin et al. 2017: 424, 1288-1289; 436, 1352). The combination of type 6 a fibulae with spindle-whorls in the closed complexes indicates that they were worn by women; the anthropological analysis of the cremated remains from grave 1 in Sotin shows that it was an adult woman. Moreover, grave goods such as spinning equipment from similar graves prove that these women had skills that guaranteed them a certain status in the community, judging by other goods in the graves.

\section{FAREWELL GIFTS}

Grave 1 contained not only the urns and the lid, but also a ceramic set consisting of eight vessels (Fig. 7). The custom of laying ceramic sets in graves was common at the end of the Late Bronze Age and especially in the initial phases of the Early Iron Age in the area of the Middle Danube Basin or the eastern Hallstatt sphere (Nebelsick 1994: 312-315, 357, Fig. 4; 1997: 32; Metzner-Nebelsick 2002: 179-180, Figs. 79-80; Nebelsick 2016: 22-31).

The ceramic set combining three pots with liquids and two bowls with food points to the custom of providing farewell gifts for the voyage to the hereafter, which was common practice in the cemeteries of the Dalj group (Vinski-Gasparini 1983: 609; Metzner-Nebelsick 2002: 179-180, Figs. 79-80; Trajković 2008: 19). The three large pots contained liquids, which can be deduced from the kantharos and the cup found in two pots. The size of the pots, and the combination of the context with drink recipients that is very common in the eastern Hallstatt sphere, indicate their static function in the drinking ceremony, which is associated with the chthonic part of the funerary rites and the ritual drama taking place during the funeral (Nebelsick 2016: 22-23). Still, nothing precise can be said about the actual contents of the pots before performing residue analyses.

One bowl included a piece of the neck, a smaller piece of the loin, and upper portions of the ribs of a young goat or sheep. Unburned pieces of meat were a common grave good ever since the Late Bronze Age in the eastern Carpathian Basin and along the Danube (Ložnjak Dizdar, Rajić Šikanjić 2016: 117, Fig. 5). These unburned pieces of meat were laid in graves in Doroslovo, where it was recorded that the animal bones of sheep/goat were found in bowls, but also under the vessels in graves (Blažić 2008: 360, 363, Tab. 1). Sheep meat was also laid in graves in the cemeteries of Füzesabony, Sirok, Maklár, and Dormánd in the Tisza Basin (Metzner-Nebelsick 1998: Fig. 7; 10). An interesting parallel for the concept of farewell gifts is grave 17 from Doroslovo, which contained an urn, three pots, three bowls, and two kantharoi. The urn contained parts of ribs and vertebrae of a sheep/goat (Trajković 2008: 41-43, grave 17, 1-10; Blažić 
grob 17, 1-10; Blažić 2008: 368). Na žalost, ne postoje podaci o antropološkoj analizi da bi se moglo provjeriti je li i u dobi i spolu pokojnika postoji sličnost.

Količina i sastav te popudbine zasigurno je ovisila o ekonomskim mogućnostima zajednice - bliže rodbine koja je ispraćala pokojnika, odnosno ona može posredno svjedočiti o statusu pokojnika i njegovih bližnjih u zajednici. Usporedba faune na istovremenim naseljima u regiji pokazuje kako su ovce/koze zastupljene u fauni u manjem broju u odnosu na goveda, ali približno u sličnome broju kao domaće svinje, pri čemu je vidna razlika u odnosu prilaganja ovčjeg/ kozjeg mesa u grobovima u Doroslovu u odnosu na meso svinje (Blažić 2008: graf 1). Vidljivo je i kako su meso ovce/ koze prilagani u manjem broju u odnosu na goveđe meso (Blažić 2008: graf 1). Razlozi mogu biti ritualni, ali svakako su ovisili i o ekonomskim mogućnostima. Komad mesa mlađe ovce/koze može se tumačiti kao dio pogrebne gozbe koji je bio priložen u grob, pri čemu se samo može nagađati je li sadržina bila povezana i s prehrambenim navikama pokojnika za života. Lonci većih zapremina govore i o većoj količini tekućine koja je bila priložena u ovome grobu.

\section{DVOJNI GROBOVI}

Dvojni grobovi nisu rijetkost tijekom starijega željeznog doba na prostoru istočnoga halštatskog kruga. Nekoliko istovremenih dvojnih grobova, dokazanih provedenim antropološkim analizama, pronađeni su na prostoru daljske grupe: grob 36 u Batini, grobovi 50 i 51 u Doroslovu. Dvojni grob 36 odrasle osobe i djeteta pronađen je u Batini (Bojčić et al. 2018: 163-170), pri čemu je koncept samoga pokopa proveden na sasvim drugačiji način u odnosu na primjer groba 1 iz Sotina. Na način depozicije spaljenih kostiju u grobu možda je utjecala starost djeteta koja je u grobu 36 iz Batine antropološkom analizom određena između 6 i 11 godina. Većina spaljenih kostiju djeteta bila je pohranjena $u$ žaru, dok je drugi dio kostiju djeteta pomiješan s ostacima spaljenih kostiju odrasle osobe i bio je položen na posebnoj hrpici u grobnoj raci (Bojčić et al. 2018: 163, Figs. 1-2). Ovaj grob datiran je u kraj Illa stupnja. U Doroslovu su dva primjera dvojnih pokopa grobovi 50 i 51 sa spaljenim ostacima odraslih ženskih osoba s djecom sa zanimljivim scenarijem pokopa (Živanović 2008: tab. 3) koji se mogu datirati u približno isto vrijeme kao i grob 1 iz Sotina (Trajković 2008: 72-76, grob 50, 1-15; grob 51, 1-22). U grobu 50 zajedno su pronađene pomiješane spaljene kosti odrasle pokojnice (maturus) i maloga djeteta (infans I) koje su položene u jednu žaru. Od keramičkoga servisa još su bili položeni lonac, četiri zdjele, kantharos i šalica. U žari su bili prilozi željeznoga noža, tri brončana svitka te još pet ulomaka brončanih svitaka, kameni privjesak i tri kamena oblutka (Trajković 2008: 72-74, grob 50, 1-15). U drugome grobu 51 pronađene su dvije žare, pri čemu su u jednoj bile izdvojene kosti djeteta (infans l) pomiješane s kostima odrasle ženske osobe (maturus), a u drugoj ostatak spaljenih kostiju odrasle ženske osobe. U jednoj žari pronađeni su čaša i četiri brončana svitka, dok je u drugoj bilo osam brončanih svitaka te ulomci još dva brončana svitka i željezni obruč. Od keramičkoga servisa u grobu su bili cjelovito sačuvani kantharos kao i ulomak
2008: 368). Unfortunately, there are no data on an anthropological analysis that would verify whether there is a similarity in the age or sex of the deceased.

The quantity and composition of the farewell gifts must have depended on the economic possibilities of the community, or the close relatives sending the deceased on their way, meaning that it can give indirect evidence on the status of the deceased and their close relatives in the community. The comparison of the fauna in the contemporary settlements in the region has shown that sheep/goats were fewer than cattle, but approximately as numerous as domesticated pigs, with a clear difference in the laying of sheep/goat meat into the graves in Doroslovo as opposed to pig meat (Blažić 2008: Graph 1). It is clear that sheep/goat meat was laid less often than cattle meat (Blažić 2008: Graph 1). Reasons can be ritual, but they certainly depended on economic capabilities too. A piece of meat of a young sheep/goat can be interpreted as a part of a funerary feast that was placed in the grave, but it can only be hypothesized whether the content was related to the dietary habits of the deceased. Large pots testify about the large quantity of liquids that was laid in this grave.

\section{DOUBLE GRAVES}

Double graves were not a rarity in the Early Iron Age in the area of the eastern Hallstatt sphere. Several contemporary double graves, proven through anthropological analyses, were found in the area of the Dalj group: grave 36 in Batina, graves 50 and 51 in Doroslovo. Double grave 36 of an adult and a child was found in Batina (Bojčić et al. 2018: 163-170), but the concept of the burial itself was realised in a completely different way than the example of grave 1 from Sotin. The method of placing the cremated bones into the grave could have been influenced by the age of the child in grave 36 from Batina, which was determined by the anthropological analysis to be between 6 and 11. Most cremated bones of the child were laid in an urn, while another part of the child bones was mixed with the remains of the cremated bones of the adult and laid on a special pile inside the burial pit (Bojčić et al. 2018: 163, Figs. 1-2). This grave was dated to the end of phase IIIa. In Doroslovo there are two cases of double burials: graves 50 and 51 with the cremated remains of adult women with children and an interesting burial procedure (Živanović 2008: Tab. 3) that can be dated to roughly the same period as grave 1 from Sotin (Trajković 2008: 72-76, grave 50, 1-15; grave 51, 1-22). Grave 50 contained the mixed cremated bones of an adult woman (maturus) and a small child (infans I) that were laid in a single urn. The rest of the ceramic set consisted of a pot, four bowls, a kantharos, and a cup. The urn contained these grave goods: an iron knife, three bronze coils, and another five fragments of bronze coils, a stone pendant, and three stone pebbles (Trajković 2008: 72-74, grave 50,1-15). In the second grave (grave 51), there were two urns, one with separate bones of the child (infans I) mixed with the bones of an adult woman (maturus), and the other with the remains of the cremated bones of an adult woman. One urn contained a glass and four bronze coils, while the other contained eight bronze coils and the fragments of another two bronze coils and an iron hoop. The ceramic set in the grave included a completely preserved kantharos and a fragment of a kantharos (Trajković 2008: 74-76, grave 51, 1-22). The description of the grave does not specify which urn contained which bo- 
kantharosa (Trajković 2008: 74-76, grob 51, 1-22). U opisu groba nije istaknuto koje kosti su se nalazile u kojoj žari, ali pretpostavljamo kako su kosti djeteta bile u žari s minijaturnom posudom. Zanimljivo je kako su u svim slučajevima odrasle osobe najvjerojatnije spaljene zajedno s djetetom na lomači, no tijekom pokopa i polaganja u grob zajednica im je drugačije polagala spaljene ostatke - ponekad ostavljala zajedno, npr. grob 50 u Doroslovu i grob 1 u Sotinu, ili odvajala i fizički: upotrebom različitih žara ili zasebnim prostorom - grob 51 u Doroslovu i grob 36 u Batini. O čemu je ovisila ta odluka zajednice: o doživljenoj dobi djeteta ili nekome drugom ritualnom razlogu ostaje nepoznanica.

U izboru osobnih predmeta sastav nalaza u prikazanim grobovima varira i može ukazivati na životne navike kao i na različite mreže kontakata kojima su zajednice u Batini, Doroslovu i Sotinu bile izložene na početku starijega željeznog doba.

\section{ZAKLJUČAK}

Grob 1 u Sotinu pripadao je odrasloj ženskoj pokojnici koja je sahranjena s vrlo malim djetetom. Scenarij pokopa u zajedničkoj žari svjedoči o bliskoj vezi pokojnice i maloga djeteta. Nošnja odrasle osobe sastojala se od fibule koja pripada tipu koji se povezuje s zapadnopanonskim prostorom Štajerske i područjem zapadne Mađarske. U grobu nisu pronađeni brončani svitci koji su pronađeni u ostalim spomenutim ženskim grobovima iz Batine i Doroslova i koji su vrlo čest prilog u ženskim grobovima daljske grupe (Ložnjak Dizdar, Rajić Šikanjić 2016: 117-120, Fig. 6: 4). Prema dijelovima nošnje i osobnim predmetima može se zaključiti kako je pokojnica nosila neuobičajenu kopču za odjeću u svojoj zajednici te je poznavala znanja izrade finoga prediva. Tip žare u koji su joj bili položeni spaljeni ostaci gotovo je kanonski tip posude u kojoj se deponiraju ostaci pokojnika na grobljima daljske grupe. Priloženi keramički set s popudbinom u grobu svjedoči o ritualu, ali i statusu pokojnice u zajednici. Lonci za piće, koji imaju lokalni oblik, u ornamentici pokazuju veze sa zapadom (nizovi kanelura i uboda te motiv rozete) - s područjem Donje Doline, Požeške kotline i jugoistočnoalpskoga područja, dok su zdjele oblikom i ukrasom lokalne izrade. Veze i pripadnost istočnome halštatskom krugu vidljiva je ne samo u izboru fibule te ornamentike na keramičkome setu, nego i u kompoziciji grobnih priloga s više posuda s popudbinom. Na području istočnoga halštatskog kruga takvi i brojem bogatiji setovi posuđa nalaze u grobovima pod tumulima koji pripadaju istaknutim pojedincima u zajednici (Nebelsick 2016: 24-29). Učestalost grobova s manjim setovima keramičkih posuda s popudbinom možda svjedoči i o egalitarnijim društvima u ovome dijelu Podunavlja tijekom starijega željeznog doba gdje izostaju pokopi pod tumulima, osim u Batini koja je jedan od centara u halštatskome svijetu (Metzner-Nebelsick 1997; Hršak et al. 2013) i gdje se broj posuda u grobovima može tumačiti složenom ritualnom praksom u kojoj se zrcali i status u zajednici.

Pokojnica iz groba 1 u Sotinu bila je ugledna članica svoje zajednice sudeći prema načinu na koji je pokopana sa svojim bliskim članom obitelji, osobnim predmetima i stilski nes, but we assume that the bones of the child were inside the urn with the miniature vessel. Interestingly, in each case, the adult was probably cremated on the pyre together with the child, but during the burial and laying into the grave, the community placed their remains differently: sometimes they were left together, as in grave 50 in Doroslovo and grave 1 in Sotin, and sometimes they were physically separated by using different urns or a separate space, as in grave 51 in Doroslovo and grave 36 in Batina. It is still unclear whether this decision of the community depended on the perceived age of the child or some other ritual reason.

Regarding the choice of personal items, there are differences in the composition of the finds in the presented graves, which may point to life habits or different networks of contacts to which the communities in Batina, Doroslovo, and Sotin, were exposed at the beginning of the Early Iron Age.

\section{CONCLUSION}

Grave 1 in Sotin belonged to an adult woman who was buried with a very small child. The procedure of burying them in a single urn testifies to the close relationship between the woman and the small child. The costume of the adult consisted of a fibula belonging to a type associated with the western Pannonian area of Styria and the area of western Hungary. The grave did not contain bronze coils like the other mentioned female graves from Batina and Doroslovo; these coils were a very frequent grave good in women's graves of the Dalj group (Ložnjak Dizdar, Rajić Šikanjić 2016: 117-120, Fig. 6: 4). On the basis of costume items and personal items, it can be concluded that the woman carried a clothing buckle that was unusual in her community and that she was skilled in producing fine yarn. The urn type containing her cremated remains is almost the canonical vessel type used for the remains of the dead in the cemeteries of the Dalj group. The addition of the ceramic set with farewell gifts inside the grave testifies about the ritual, but also about the status of that woman in the community. The ornamentation of the pots for drinks, which have a local shape, shows connections with the west (series of flutes and stabs and the motif of a rosette) - with the area of Donja Dolina, the Požega Valley, and the south-eastern Alpine region, while the bowls had local shapes and decorations. The connection with and belonging to the eastern Hallstatt sphere can be seen not only in the choice of fibula and the ornamentation of the ceramic set, but also in the composition of the grave goods with several vessels with farewell gifts. In the area of the eastern Hallstatt sphere, such vessel sets with many pieces are found in the graves under tumuli which belonged to distinguished members of the community (Nebelsick 2016: 24-29). The high frequency of graves with smaller sets of ceramic vessels with farewell gifts may testify about more egalitarian societies in this part of the Danube Basin during the Early Iron Age, without burials under tumuli, except in Batina, which is one of the centres of the Hallstatt world (Metzner-Nebelsick 1997; Hršak et al. 2013) and where the number of the vessels in the graves can be interpreted through complex ritual practices reflecting the status in the community.

The woman from grave 1 in Sotin was a distinguished member of her community, judging by the way in which she was buried with a close member of her family, personal items, and a stylistically uniform ceramic set with rich 
ujednačenim keramičkim setom s bogatom popudbinom u vrijeme kasnoga 8. i prve polovice 7. st. pr. Kr.

\section{ZAHVALE}

Ovaj rad rezultat je dugogodišnjih istraživanja, od arheoloških iskopavanja, dokumentiranja i brojnih analiza. Rad je nastao dijelom u okviru istraživačkoga projekta Hrvatske zaklade za znanost (IP-06-2016-1749): Iron Age Female Identities in the Southern Carpathian Basin (FEMINE). Bez pomoći i truda mnogih, ovaj članak ne bi mogao biti napisan. Želim zahvaliti Gradskome muzeju Vukovar na podršci pri provedbi iskopavanja u Sotinu, prije svega bivšoj kustosici gđi Mireli Hutinec koja je od 2008. do 2013. sudjelovala u iskopavanjima u Sotinu i znatno pridonijela njihovoj uspješnoj provedbi. Zahvaljujem i današnjoj kustosici gđi Gorani Kušić na njezinome aktivnom sudjelovanju u istraživanjima u Sotinu. Predmeti iz groba 1 u Sotinu izloženi su u današnjem stalnom postavu Gradskoga muzeja Vukovar. Antropološku analizu spaljenih ljudskih ostataka provela je dr. sc. Petra Rajić Šikanjić, viša znanstvena suradnica u Institutu za antropologiju, na čemu joj srdačno zahvaljujem. Zahvalu za zooarheološku analizu životinjskih kostiju dugujem dr. sc. Siniši Radoviću, znanstvenome suradniku u Zavodu za paleontologiju i geologiju kvartara HAZU-a. Dokumentaciju za tisak priredio je Arheoplan, d.o.o., a crteže predmeta je nacrtala Miljenka Galić. Svima najtoplije zahvaljujem. Rekonstrukciju grobne cjeline in situ načinio je Krešimir Rončević, koji nije više među nama, ali njegovi radovi i dalje krase brojne arheološke publikacije.

Prijevod i lektura / Translation and proofreading Marko Maras farewell gifts at the time of the late $8^{\text {th }}$ cent. and the first half of the $7^{\text {th }}$ cent. BC.

\section{ACKNOWLEDGMENTS}

This paper is the result of many years of research, from archaeological excavations and records to numerous analyses. The paper was partly created within the research project of the Croatian Science Foundation (IP-06-2016-1749): Iron Age Female Identities in the Southern Carpathian Basin (FEMINE). This paper could not have been written without the help and effort of many people. I want to thank Vukovar Town Museum for their support during the excavations in Sotin, particularly Mrs Mirela Hutinec, the former curator who participated in the Sotin excavations from 2008 to 2013 and made a significant contribution to their success. I also thank the current curator, Mrs Gorana Kušić, for her active participation in the Sotin excavations. The objects from grave 1 in Sotin are exhibited in the current permanent exhibition of Vukovar Town Museum. The anthropological analysis of cremated human remains was done by dr. sc. Petra Rajić Šikanjić, senior scientific associate in the Institute for Anthropological Research, for which she has my warm gratitute. For the zooarchaeological analysis of animal bones, I thank dr. sc. Siniša Radović, scientific associate in the Institute for Quaternary Paleontology and Geology of the Croatian Academy of Sciences and Arts. The book layout was designed by Arheoplan Ltd., and the objects were drawn by Miljenka Galić. I give my warmest thanks to everyone. The reconstruction of the funerary complex in situ was done by Krešimir Rončević, who is not with us any longer, but his work still graces many archaeological publications. 


\section{LITERATURA / BIBLIOGRAPHY}

Bader, T. 1983, Die Fibeln in Rumänien, Prähistorische Bronzefunde, Band XIV/6, C. H. Beck'sche Verlagsbuchhandlung, München.

Balen-Letunić, D. 1981, Grobovi kasnog brončanog i starijeg željeznog doba iz okolice Karlovca, Vjesnik Arheološkog muzeja u Zagrebu, Vol. XIV, 11-27.

Balen-Letunić, D. 2004, Prilog arheološkoj topografiji šarengradskog prostora, Osječki zbornik, Vol. XXVII, 15-34.

Barth, F. E. 1969, Die hallstattzeitlichen Grabhügel im Bereiche des Kutscher bei Podsemel (Slowenien), Antiquitas 3/5, Habelt, Bonn.

Blažić, S. 2008, Ostaci životinjski kostiju u grobovima halštatske nekropole Đepfeld, in: D. Trajković, Đepfeld - nekropola starijeg gvozdenog doba kod Doroslova, Gradski muzej Sombor, Sombor, 357-376.

Bojčić, Z., Dizdar, M., Hršak, T., Leleković, T. 2011, Rezultati probnih istraživanja nalazišta Batina - Sredno 2010. godine, Annales Instituti Archaeologici, Vol. VII, 13-19.

Bojčić, Z., Ložnjak Dizdar, D., Hršak, T. 2018, Nove spoznaje o kronologiji groblja Batina - Sredno na početku starijega željeznog doba, Prilozi Instituta za arheologiju u Zagrebu, Vol. 35, 159-192.

Childe, V. G. 1929, The Danube in prehistory, Oxford University Press-Clarendon Press, Oxford-New York.

Čović, B. 1987, Grupa Donja Dolina-Sanski Most, in: Praistorija jugoslavenskih zemalja V: Željezno doba, Benac A. (ed.), Akademija nauka i umjetnosti Bosne i Hercegovine, Centar za balkanološka ispitivanja, Sarajevo, 232-286.

Demo, Ž. 2009, Ranosrednjovjekovno groblje bjelobrdske kulture: VukovarLijeva Bara (X-XI stoljeće), Katalozi i monografije 6, Arheološki muzej Zagreb, Zagreb.

Dizdar, M., Hršak, T., Ložnjak Dizdar, D. 2019, Batina (Kiskőseg) is Back in the Game: the Basarabi Vessel from an Early Iron Age Grave in the Batina-Sredno Cemetery, in: Hallstatt und Italien. Festschrift für Markus Egg, Baitinger H., Schönfelder M. (eds.), Monographien des Römisch-Germanischen Zentralmuseums, Band 154, Mainz a. R., 95-115.

Dizdar, M. u tisku, The Late Hallstatt connections between the south-eastern Carpathian Basin and the Western and Central Balkans - The beautiful ladies coming from the South, u tisku.

Dobiat, C. 1980, Das hallstattzeitliche Gräberfeld von Klein-Klein und seine Keramik, Schild von Steier, Beiheft 1, Graz.

Dörer, O. 2008, Frühe Fibelformen und der Beginn der Basarabikultur in der Umgebung des Eisernen Tores, Germania, Vol. 86/2, 541-589.

Egg, M., Kramer, D. 2016, Die hallstattzeitlichen Fürstengräber von Kleinklein in der Steiermark: die beiden Hartnermichelkogel und der Pommerkogel, Monographien des Römisch-Germanischen Zentralmuseums, Band 125, Mainz a. R.

Eibner-Persy, A. 2001, Die Stellung der Frau in der Hallstattkultur anhand der bildlichen Zeugnisse, Mitteilungen der Anthropologischen Gesellschaft in Wien, Vol. 130/131, 107-136.

Fülöp, K., Váczi, G. 2016, Late Bronze Age Cremation Burials: A complex event with few remains, Hungarian Archaeology 2016 spring (ejournal), 1-7.

Gabrovec, S. 1970, Dvoznakaste ločne fibule, Doprinos k problematici začetka železne dobe na Balkanu in v jugovzhodnih Alpah, Godišnjak Centra za balkanološka istraživanja, Vol. VIII/6, 5-65.

Gabrovec, S. 1976, Zum Beginn der Hallstattzeit in Slowenien, Archeologia Austriaca, Vol. 13, Festschrift für Richard Pittioni, 588-600.

Gabrovec, S. 1987, Dolenjska grupa, in: Praistorija jugoslavenskih zemalja. V: Željezno doba, Benac A. (ed.), Akademija nauka i umjetnosti Bosne i Hercegovine, Centar za balkanološka ispitivanja, Sarajevo, 29-119.

Gavranović, M. 2007, Eine dreischleifige Bogenfibel mit dreieckiger Fußplatte aus Bosnien, Arheološki vestnik, Vol. 58, 157-166.

Gennep, A. 1909, The Rites of Passage, Routledge and Kegan Paul, London.

Gergova, D. 1987, Früh- und ältereisenzeitliche Fibeln in Bulgarien, Prähistorische Bronzefunde, Band XIV/7, C. H. Beck'sche Verlagsbuchhandlung, München.

Glunz, B. E. 1997, Studien zu den Fibeln aus dem Gräberfeld von Hallstatt, Oberösterreich, Linzer Archäologische Forschungen, Band 25, Linz.

Grahek, L. 2004, Halštatska gomila na Hribu v Metliki, Arheološki vestnik, Vol. 55, 111-206.
Gramsch, A. 2010, Ritual und Kommunikation, Altersklassen und Gesc hlecherdifferencz im spätbronze- und früheisenzeitlichen Gräberfeld Cottbus Alvensleben-Kaserne (Branderburg), Universitätsforschungen zur prähistorischen Archäologie, Band 181, Verlag Dr. Rudolf Habelt GmbH, Bonn.

Grbić, M. 1939, Preistorisko doba Vojvodine, in: Vojvodina I. Od najstarijih vremena do velike seobe, Popović D. J., Kirilović D. (eds.), Istorisko Društvo u Novom Sadu, Novi Sad, 47-60.

Grömer, K. 2016, The Art of Pehistoric Textile Making. The Development of Craft Traditions and Clothing in Central Europe, Natural History Museum Vienna, Vienna.

Guštin, M., Tiefengraber, G., Pavlovič, D., Zorko, M. 2017, Nova Tabla pri Murski Soboti, Arheologija na avtocestah Slovenije, Vol. 52/1, Zavod za varstvo kulturne dediščine Slovenije, Ljubljana.

Härke, H. 1993, Intentionale und Funktionale Daten, Ein Beitrag zur Theorie und Methodik der Gräberarchäologie, Archäologisches Korrespondenzblatt, Vol. 23/1, 141-146.

Harmadyová, K. 2016, Dvojslučková oblúkovitá spona z BratislavyDevína, Zborník Slovenskího národného Múzea, Vol. CX - Archaeológia, Vol. 26, 103-107.

Heilmann, D. 2016, Contextualising Bow Fibulae with Boeotian Shield Plates: Cultural Transfer Processes during Early Iron Age in the Central Balkan Area, Starinar, Vol. 66, 9-26.

Hladiková, K. 2011, Príspevok k problematike pohrebného rítu detí villanovskej kultúry, Zborník Filozofickej Fakulty Univerzity Komenského Musaica, Vol. XXVII, 277-295.

Hoffiller, V. 1938, Dalj, Corpus Vasorum Antiquorum, Fasc. 2, Beograd.

Hršak, T., Leleković, T., Dizdar, M. 2013, Rezultati istraživanja nalazišta Batina - Sredno 2012. godine, Annales Instituti Archaeologici, Vol. IX, 12-19.

Hršak, T., Leleković, T., Dizdar, M. 2017, Rezultati istraživanja nalazišta Batina - Sredno 2016. godine, Annales Instituti Archaeologici, Vol. XIII, 40-45.

Hutinec, M., Ložnjak Dizdar, D. 2010, Arheološke spoznaje o Sotinu. Rezultati probnih istraživanja 2008.-2010., Gradski muzej Vukovar, Vukovar.

Križ, B. 1997, Kapiteljska njiva, Novo mesto, Dolenjski muzej, Novo Mesto.

Križ, B., Stipančić, P., Škedelj Petrič, A. 2009, Arheološka podoba Dolenjske, Dolenjski muzej, Novo Mesto.

Križ, B. 2019, Novo Mesto VIII. Kapiteljska njiva. Način pokopa v starejši žele zni dobi, Carniola archaeologica 8, Dolenjski muzej, Novo Mesto.

Ložnjak Dizdar, D. 2004, Odnos daljske i bosutske grupe na prostoru hrvatskog Podunavlja, Prilozi Instituta za arheologiju u Zagrebu, Vol. 24, 19-35.

Ložnjak Dizdar, D. 2015, Slatina/Berezine - Early Iron Age graves in Central Podravina, in: Beiträge zur Hallstattzeit am Rande der Südostalpen. Akten des 2. Internationalen Symposiums am 10. und 11. Juni 2010 in Wildon (Steiermark/Österreich), Gutjahr Ch., Tiefengraber G. (eds.), Maria Leidorf Verlag GmbH, Rahden/Westf., 29-43.

Ložnjak Dizdar, D. 2019, Notes on several finds from the beginning of the Early Iron Age in the Danube area, in: Papers in Honour of Rastko Vasić 80th Birthday, Filipović V., Bulatović A., Kapuran A. (eds.), Institute of Archaeology, Belgrade, 247-257.

Ložnjak Dizdar, D., Rajić Šikanjić, P. 2016, Funerary Practices at the End of the Late Bronze Age in the southern Middle Danube Region, in: Funerary Practices during the Bronze and Iron Ages in Central and southeast Europe, Sîrbu V., Jevtić M., Dmitrović K., Ljuština M. (eds.), Proceedings of the $14^{\text {th }}$ International Colloquium of Funerary Archaeology in Čačak, Serbia, $24^{\text {th }}-27^{\text {th }}$ September 2015 , Faculty of Philosophy, University of Belgrade-National museum Čačak, Beograd-Čačak, 109-126.

Ložnjak Dizdar, D., Rajić Šikanjić, P. u tisku, Childhood in the Late Bronze and Early Iron Age in the southern Carpathian Basin, in: Ages and abilities: the stages of childhood and their social recognition in prehistoric Europe and beyond, Rebay-Salisbury K., Pany-Kucera D. (eds.), SSCIP Monograph.

Ložnjak Dizdar, D., Ilkić, M., Hutinec, M. 2009, Sotin - Srednje polje, probna arheološka istraživanja 2008. g., Annales Instituti archaeologici, Vol. V, 12-14.

Ložnjak Dizdar, D., Dizdar, M., Kušić, G. 2018, Sotin - Srednje polje, istraživanje višeslojnog nalazišta u Podunavlju 2017., Annales Instituti 
archaeologici, Vol. XIV, 28-33.

Márton, L. A. 1913, Magyarhoni fibulák osztályozása, Archaeologia Értesitö, Vol. XXXIII, 141-159.

Medović, P. 1978, Naselja starijeg gvozdenog doba ujugoslovenskom Podunavlju, Dissertationes et Monographiae XXII, Savez Arheoloških Društava Jugoslavije, Beograd.

Medović, P., Medović, I. 2011, Gradina na Bosutu - naselje starijeg gvozdenog doba, Platoneum, Novi Sad.

Metzner-Nebelsick, C. 1996, Die Urnenfelder- und Hallstattzeit in Südostpannonien - eine Region im Spannungsfeld zwischen Osthallstattkreis, karpatenländisch-balkanischer Eisenzeit und Steppenkultur, in: Die Osthallstattkultur, Jerem E., Meid W. (eds.), Akten des Internationalen Symposiums, Sopron 1994, Archaeolingua, Band 7, Budapest, 283-314.

Metzner-Nebelsick, C. 1997, Hallstattzeitliche Zentren in Südostpannonien, Zalai Múzeum, Vol. 8, 9-26.

Metzner-Nebelsick, C. 1998, Abschied von den «Thrako-Kimmeriern»? - Neue Aspekte der Interaktion zwischen karpatenländischen Kulturgruppen der späten Bronze- und frühen Eisenzeit mit der osteuropäischen Steppenkoine, in: Das Karpatenbecken und die osteuropäische Steppe, Hänsel B., Machnik J. (eds.), Prähistorische Archäologie in Südosteuropa, Band 12, München, 361-422.

Metzner-Nebelsick, C. 2002, Der «Thrako-Kimmerische» Formenkreis aus der Sicht der Urnenfelder- und Hallstattzeit im südöstlichen Pannonien, Vorgeschichtliche Forschungen, Band 23, Verlag Marie Leidorf $\mathrm{GmbH}$, Rahden/Westf.

Mihelić, S. 2009, Pretpovijesni nalazi iz Aljmaša i pitanje zlatnog nalaza iz Dalja, Vjesnik Arheološkog muzeja u Zagrebu, 3. ser. Vol. XLII, 105-128.

Minichreiter, M. 1985, Erdut «Veliki Varod, Mali Varod, Žarkovac», Osijek višeslojno prapovijesno naselje, Arheološki pregled, Vol. 24, 25-30.

Müller-Karpe, H. 1959, Beiträge zur Chronologie der Urnenfelderzeit nördlich und südlich der Alpen, Römisch-Germanische Forschungen, Band 22, Walter de Gruyter GmbH, Berlin.

Nebelsick, L. D. 1994, Der Übergang von der Urnenfelder- zur Hallstattzeit am nördlichen Ostalpenrand und im nördlichen Transdanubien, in: Archäologische Untersuchungen zum Übergang von der Bronze- zur Eisenzeit zwischen Nordsee und Kaukasus, Schauer P. (ed.), Regensburger Beiträge zur Prähistorischen Archäologie, Band 1, Universitätsverlag Regensburg, Regensburg, 307-363.

Nebelsick, L. D. 1997, Die Kalenderberggruppe der Hallstattzeit am Nordostalpenrand, in: Hallstattkultur im osten Österreichs, Nebelsick L. D., Eibner A., Lauermann E., Neugebauer J. W. (eds.), Niederösterreichisches Pressehaus, St. Pölten, 9-128.

Nebelsick, L. D. 2016, Drinking against death. Studies on the materiality and iconography of ritual, sacrifice and transcendence in later prehistoric Europe, Wydawnictwo Uniwersytetu Kardynała Stefana Wyszynskiego, Warszawa.

Pare, Ch. F. E. 1999, Beiträge zum Übergang von der Bronze- zur Eisenzeit in Mitteleuropa. Teil I, Grundzüge der Chronologie im östlichen Mitteleuropa (11.-8. Jahrhundert v. Chr.), Jahrbuch des RömischGermanischen Zentralmuseum Mainz, Vol. 45/1 (1998), 293-433.

Parzinger, H. 1988, Chronologie der Späthallstatt und Frühlatène zeit. Studien zu Fundgruppen zwischen Mosel und Save, Qullen und Forschungen zur prähistorischen und provinzialrömischen Archäologie, Band 4, Acta Humaniora, VCH Verlagsgesellschaft, Weinheim.

Parzinger, H. 1989, Hallstattzeitliche Grabhügel bei Dobrnič, Arheološki vestnik, Vol. 39-40 (1988-1989), 529-636.

Patek, E. 1981, Die Beziehungen zwischen Transdanubien und dem jugoslawischen Donaugebiet in der Früheisenzeit, Materijali Saveza arheoloških društava Jugoslavije, Vol. XIX, Novi Sad, 189-200.

Patek, E. 1982, Recent excavations at the Hallstatt and La Tène Hill-fort of Sopron-Várhely (Burgstall) and the predecessors of the Hallstatt culture in Hungary, British Archaeological Reports IS 144, 1-56.

Patek, E. 1983, Neue Untersuchungen auf dem Burgstall bei Sopron, Bericht der Römisch-Germanischen Kommission, Band 63 (1982), 105-177.

Patek, E. 1993, Westungarn in der Hallstattzeit, Quellen und Forschungen zur prähistorischen und provinzialrömischen Archäologie, Band 7, Acta Humaniora, VCH Verlagsgesellschaft, Weinheim.

Popović, D. 1981, Keramika starijeg gvozdenog doba u Sremu, Fontes Archaeologiae lugoslaviae, Tome IV, Savez Arheoloških Društava Jugoslavije, Beograd.
Popović, P., Vukmanović, M. 1998, Vajuga-Pesak, Nekropola starijeg gvozdenog doba, Đerdapske sveske, Posebna izdanja 3, Beograd.

Potrebica, H. 2003, Požeška kotlina i Donja Dolina u komunikacijskoj mreži starijeg željeznog doba, Opuscula archaeologica, Vol. 27, 217-242.

Schnurbein, S. (ed.) 2009, Atlas der Vorgeschichte. Europa von den ersten Menschen bis Christi Geburt, Konrad Theiss Verlag, Stuttgart.

Sofaer, J. 2015, Clay in the Age of Bronze, Essays in the Archaeology of Prehistoric Creativity, Cambridge University Press, New York.

Sofaer, J., Stig Sørensen, M. L. 2013, Death and Gender, in: Oxford Handbook of The Archaeology of Death and Burial, Tarlow S., Nilsson Stutz L. (eds.), Oxford University Press, Oxford, 527-541.

Stöllner, T. 1994, Eine «herrschaftliche» Familie der Hallstattzeit von «Gansfuß» bei Gilgenberg?, in: Festschrift für Otto-Herman Frey zum 65. Geburstag, Böhme H. W., Dobiat C. (eds.), Marburger Studien zur Vor- und Frühgeschichte, Band 16, Marburg, 625-652.

Šimić, J. 2004, Grupa Dalj, in: Ratnici na razmeđu istoka i zapada, Starije željezno doba u kontinentalnoj Hrvatskoj, Balen-Letunić D. (ed.), Katalog izložbe, Arheološki muzej u Zagrebu, Zagreb, 36-77.

Škvor Jernejčić, B. 2017, Grobovi iz starejšega halštatskega obdobja na Molniku, in: S. Tecco Hvala, Molnik pri Ljubljani v železni dobi, Opera Instituti Archaeologici Sloveniae 36, Ljubljana, 89-108.

Škoberne, Ž., Bugar, A. 2017, Od Budinjaka do Mainza, Muzej grada Zagreba, Zagreb.

Tasić, N. 1971, Bosutska grupa-nova kultura starijeg gvozdenog doba na području Vojvodine i uže Srbije, Materijali Saveza arheoloških društava Jugoslavije, Vol. VII, Beograd, 61-83.

Tasić, N. 1994, Nekropola kod Doroslova i njen značaj za proučavanje starijeg gvozdenog doba Podunavlja, in: Kulture gvozdenog doba jugoslovenskog Podunavlja, Tasić N. (ed.), Balkanološki institut SANU, Posebna izdanja 55, Beograd, 9-19.

Tecco-Hvala, S. 2012 Magdalenska gora. Družbena struktura in grobni rituali železnodobne skupnosti, Opera Instituti Archaeologici Sloveniae 26, Ljubljana.

Teržan, B. 1990, Starejša železna doba na Slovenskem Štajerskem, Katalogi in monografije 25, Narodni muzej, Ljubljana.

Teržan, B. 1996, Weben und Zeitmessen im südostalpinen und westpannonischen Gebiet, in: Die Osthallstattkultur, Jerem E., Meid W. (eds.), Akten des Internationalen Symposiums, Sopron 1994, Archaeolingua, Band 7, Budapest, 507-536.

Teržan, B. 2000, Bronzezeit und ältere Eisenzeit im ö. Mitteleuropa, Beziehungen zum Mittemeergebiet, in: Fibel und Fibeltracht, Studienausgabe Reallexikon der Germanischen Altertumskunde, Beck H., Steuer H. (eds.), Walter de Gruyter, Berlin-New York, 34 (444)-46 (456).

Teržan, B. 2009, Kaukasisches Symbolgut in Südosteuropa - Bemerkungen zu Goldfibeln von Michalków - Fokoru - Dalj, in: Der Schwarzmeerraum vom Äneolithikum bis in die Früheisenzeit (5000-500 v. Chr.), Kommuniktionseben zwischen Kauskasus und Karpaten, Apakidze J., Govedarica B., Hänsel B. (eds.), Internationale Fachtung von Humbolddtianern für Humboldtianer im Humboldt-Kolleg in Tiflis/Georgien (17.-20. Mai 2007), Prähistorische Archäologie in Südosteuropa, Band 25, Verlag Marie Leidorf GmbH, Rahden/ Westf., 190-216.

Teržan, B., Trampuž, N. 1973, Prispevek k kronologiji svetolucijske skupine, Arheološki vestnik, Vol. XXIV, 416-460.

Tomedi, G. 2002, Das hallstattzeitliche Gräberfeld von Frög, Die Altgrabungen von 1883 bis 1892, Archaeolingua, Band 14, Budapest.

Trajković, D. 2008, Đepfeld - Nekropola starijeg gvozdenog doba kod Doroslova, Gradski muzej Sombor, Sombor.

Truhelka, C. 1904, Der vorgeschichtliche Pfahlbau im Savebette bei Donja Dolina (Bezirk Bosnisch-Gradiška), Bericht über die Ausgrabungen bis 1904., Wissenschaftliche Mitteilungen aus Bosnien und der Herzegowina, Band IX, 1-156.

Vasić, R. 1977, The Chronology of the Early Iron Age in Serbia, British Archaeological Report SS 31, Oxford.

Vasić, R. 1987, Bosutska grupa, in: Praistorija jugoslavenskih zemalja. V: Željezno doba, Benac A. (ed.), Akademija nauka i umjetnosti Bosne i Hercegovine, Centar za balkanološka ispitivanja, Sarajevo, 536-554.

Vasić, R. 1995, Gütertausch und Fernbeziehungen im früheisenzeitlichen Serbien, in: Handel, Tausch und Verkehr im bronze- und früheisenzeitlichen Südosteuropa, Hänsel B. (ed.), Prähistorische Archäologie in Südosteuropa, Band 11, München-Berlin, 349-362. 
Vasić, R. 1999, Die Fibeln im Zentralbalkan, Prähistorische Bronzefunde, Band XIV/12, Franz Steiner Verlag, Stuttgart.

Vasić, R. 2008, Doroslovo, in: D. Trajković, Đepfeld - Nekropola starijeg grozdenog doba kod Doroslova, Gradski muzej Sombor, Sombor, 337-354.

Vasić, R. 2010, Die Halsringe im Zentralbalkan (Vojvodina, Serbien, Kosovo und Mazedonien), Prähistorische Bronzefunde, Band XI/7, Franz Steiner Verlag, Stuttgart.

Vidović, J. 2003, Pogrebni ritus u grobnim humkama na području Međimurja, Izdanja Hrvatskog arheološkog društvo, Vol. 21, 57-78.

Vinski, Z. 1959, Ausgrabungen in Vukovar, Archaeologica lugoslavica, Vol. III, 99-109.

Vinski, Z., Vinski-Gasparini, K. 1962, O utjecajima istočno-alpske halštatske kulture i balkanske ilirske kulture na slavonsko-sremsko Podunavlje, Arheološki radovi i rasprave, Vol. II, 263-293.
Vinski-Gasparini, K. 1973, Kultura polja sa žarama u sjevernoj Hrvatskoj, Monografije sv. 1, Filozofski fakultet, Zadar.

Vinski-Gasparini, K. 1978, Osvrt na istraživanja kasnog brončanog i starijeg željeznog doba u sjevernoj Hrvatskoj, Izdanja Hrvatskog arheološkog društva, Vol. 2, 129-148.

Vinski-Gasparini, K. 1983, Kultura polja sa žarama sa svojim grupama, in: Praistorija jugoslavenskih zemalja. IV: Bronzano doba, Benac A. (ed.), Akademija nauka i umjetnosti Bosne i Hercegovine, Centar za balkanološka ispitivanja, Sarajevo, 547-646.

Vinski-Gasparini, K. 1987, Grupa Martijanec-Kaptol, in: Praistorija jugoslavenskih zemalja. V: Željezno doba, Benac A. (ed.), Akademija nauka i umjetnosti Bosne i Hercegovine, Centar za balkanološka ispitivanja, Sarajevo, 182-231.

Živanović, S. 2008, Antropološka analiza, in: D. Trajković, Đepfeld - Nekropola starijeg gvozdenog doba kod Doroslova, Gradski muzej Sombor, Sombor, 379-392. 


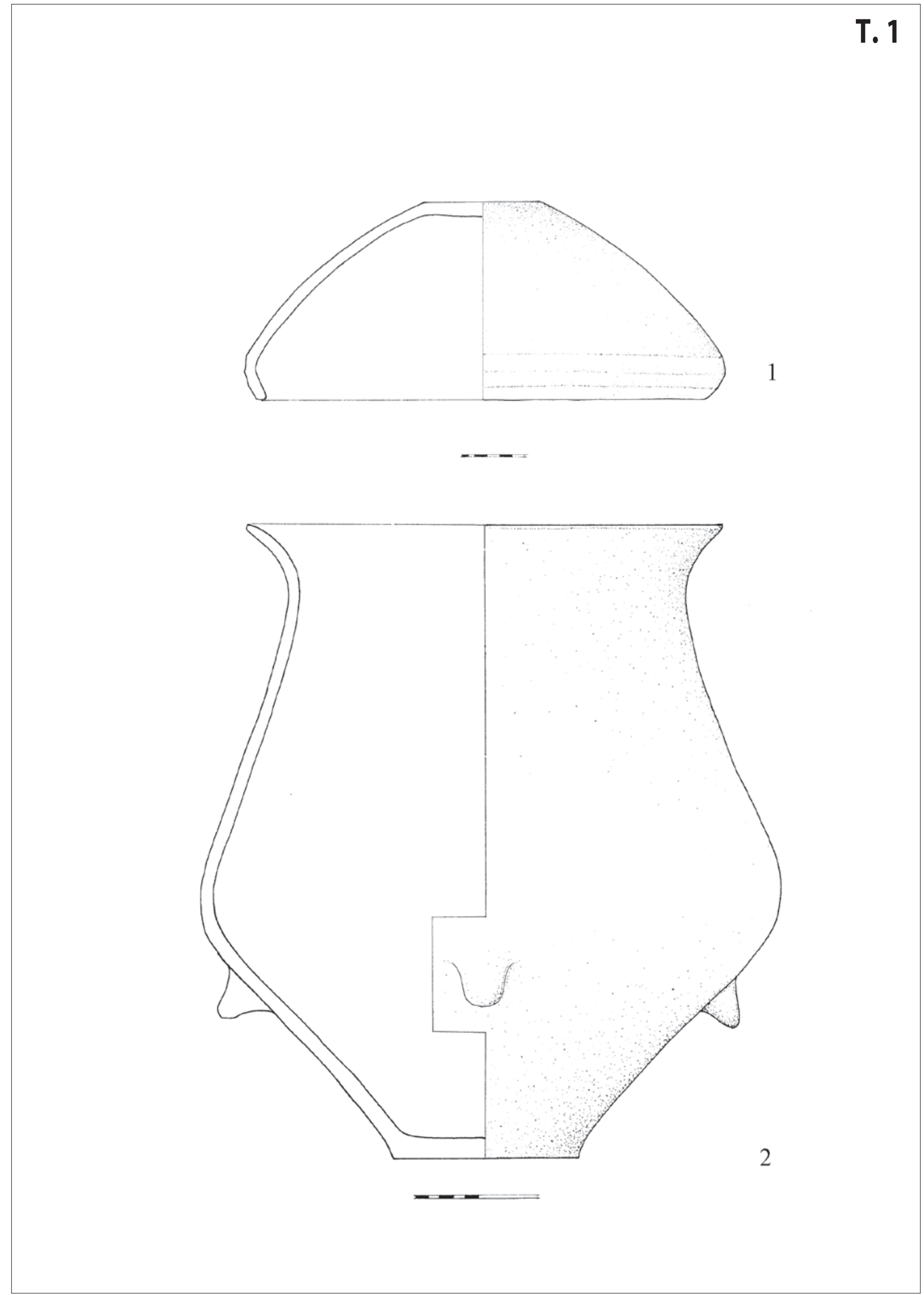

T. 1 Sotin - grob 1 (crtež: M. Galić)

Pl. 1 Sotin - grave 1 (drawning by: M. Galić) 


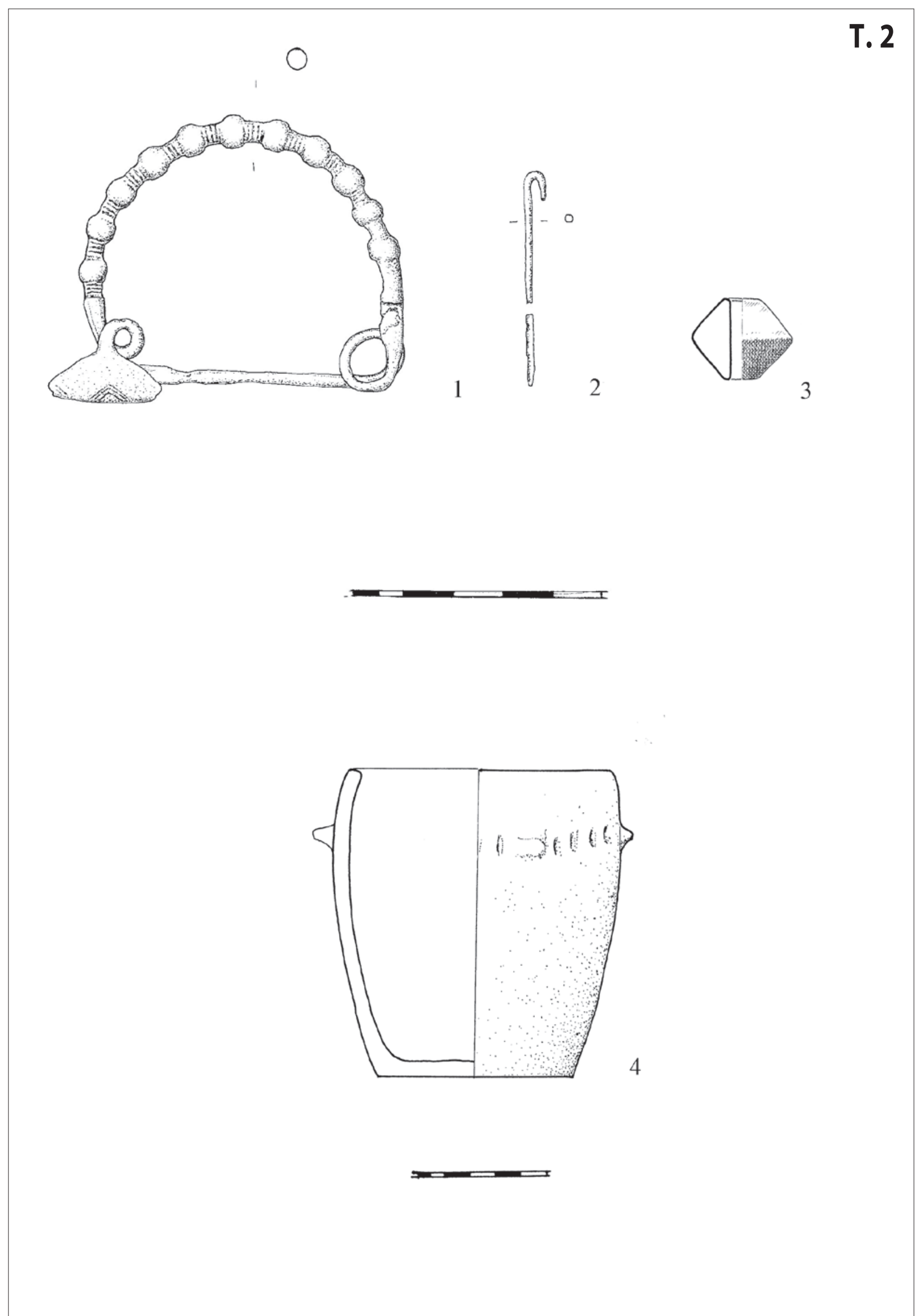

T. 2 Sotin - grob 1 (crtež: M. Galić)

Pl. 2 Sotin-grave 1 (drawning by: M. Galić) 


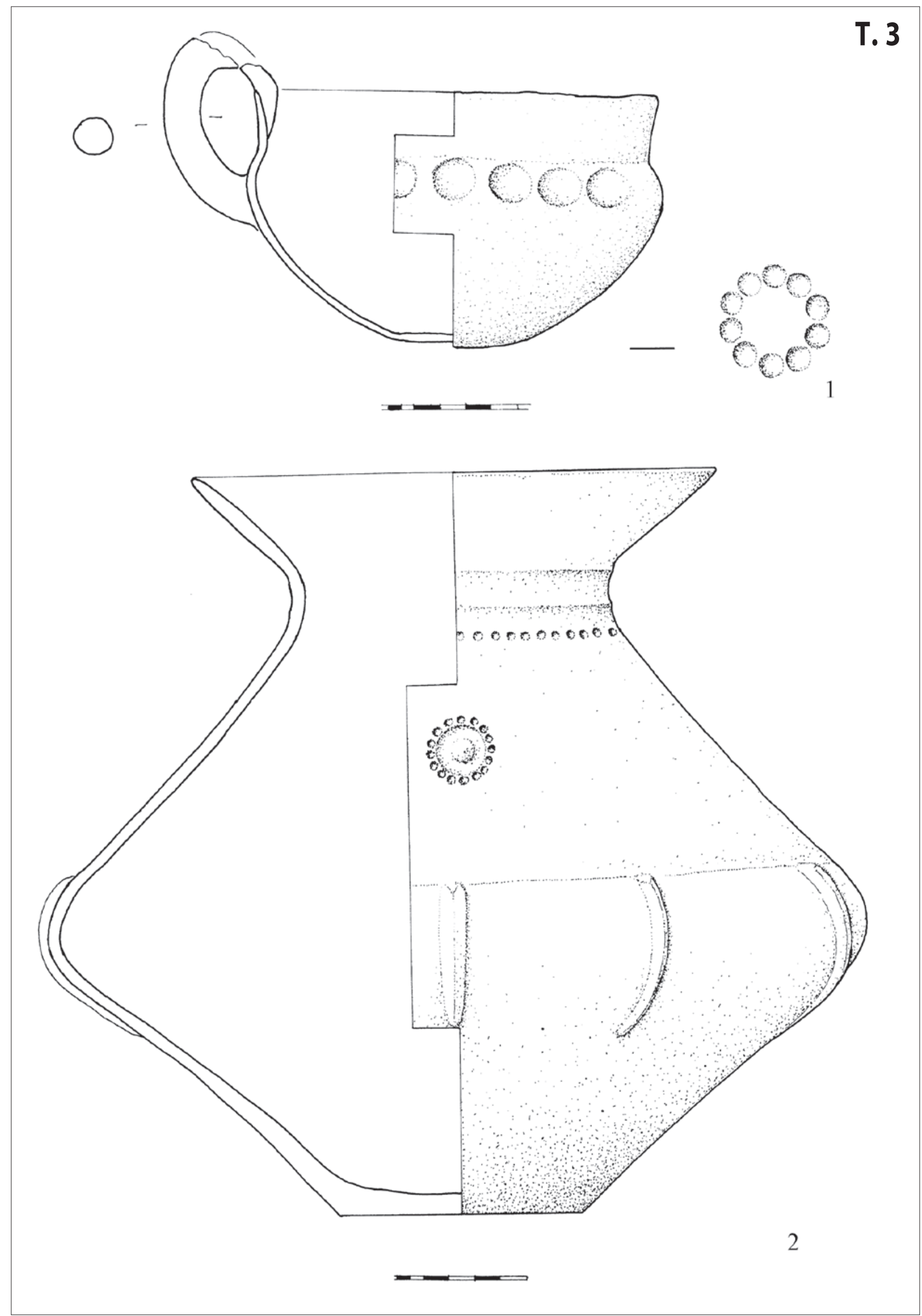

T. 3 Sotin - grob 1 (crtež: M. Galić)

Pl. 3 Sotin - grave 1 (drawning by: M. Galić) 


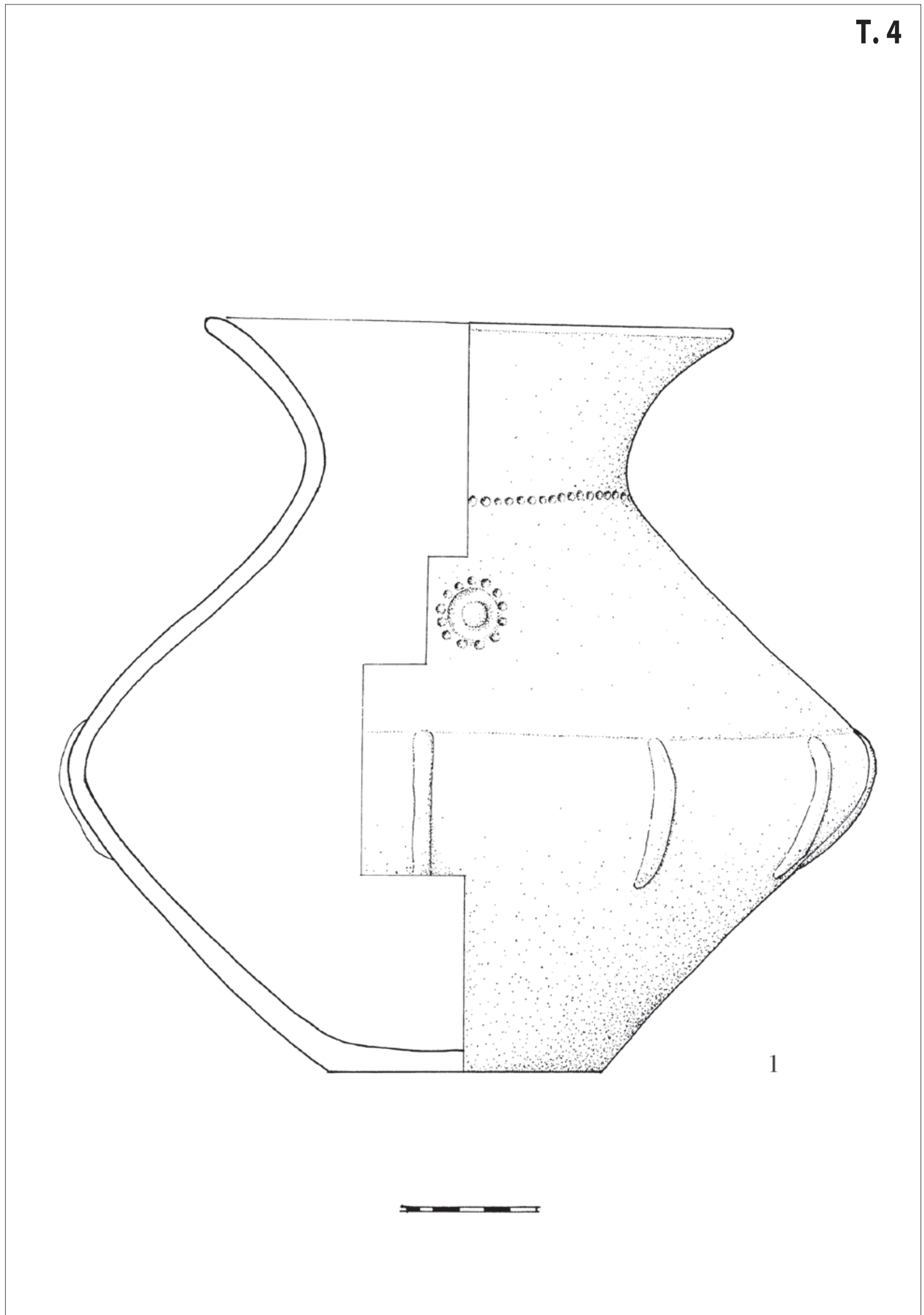

T. 4 Sotin - grob 1 (crtež: M. Galić)

Pl. 4 Sotin-grave 1 (drawning by: M. Galić) 


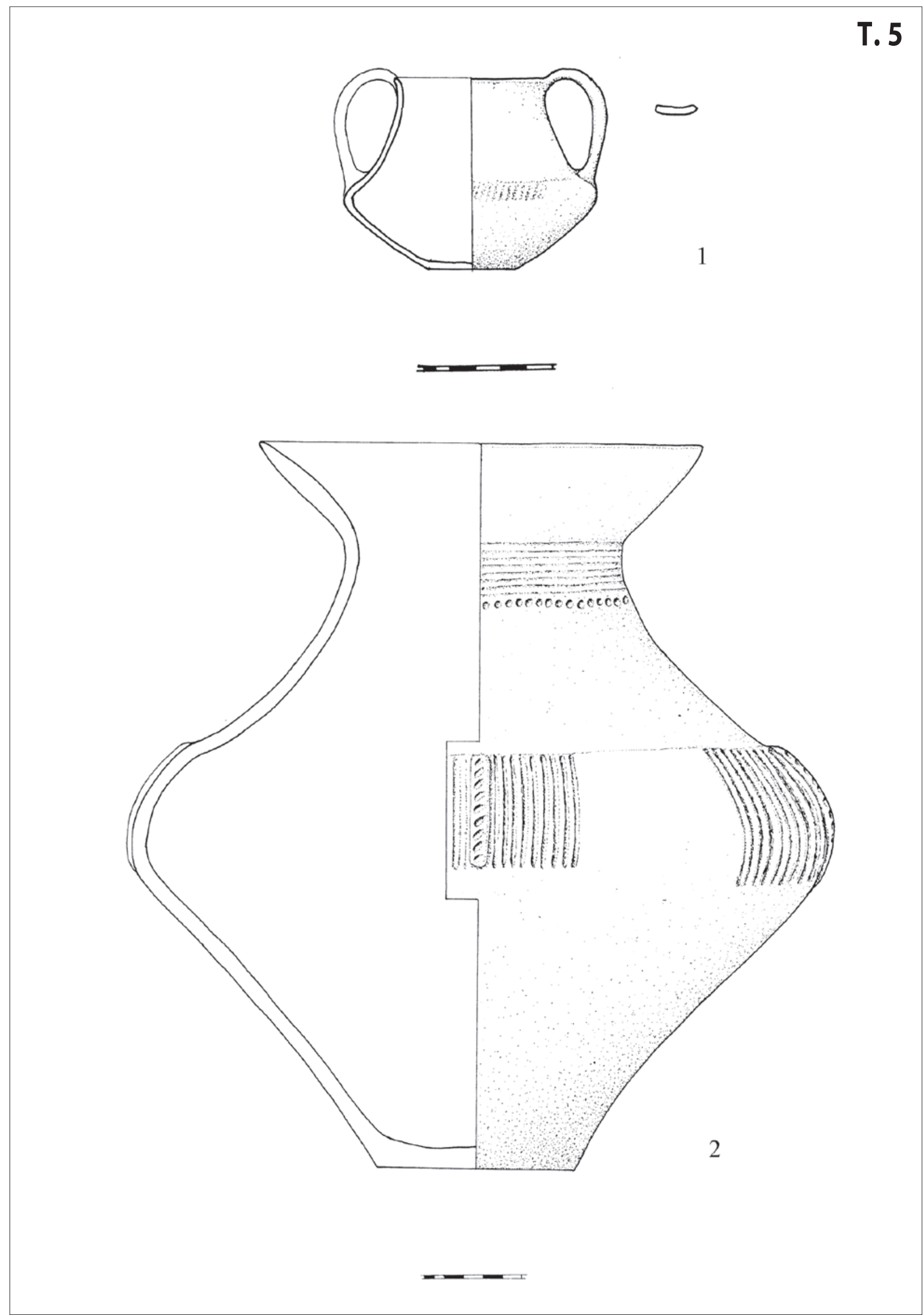

T. 5 Sotin - grob 1 (crtež: M. Galić)

Pl. 5 Sotin-grave 1 (drawning by: M. Galić) 


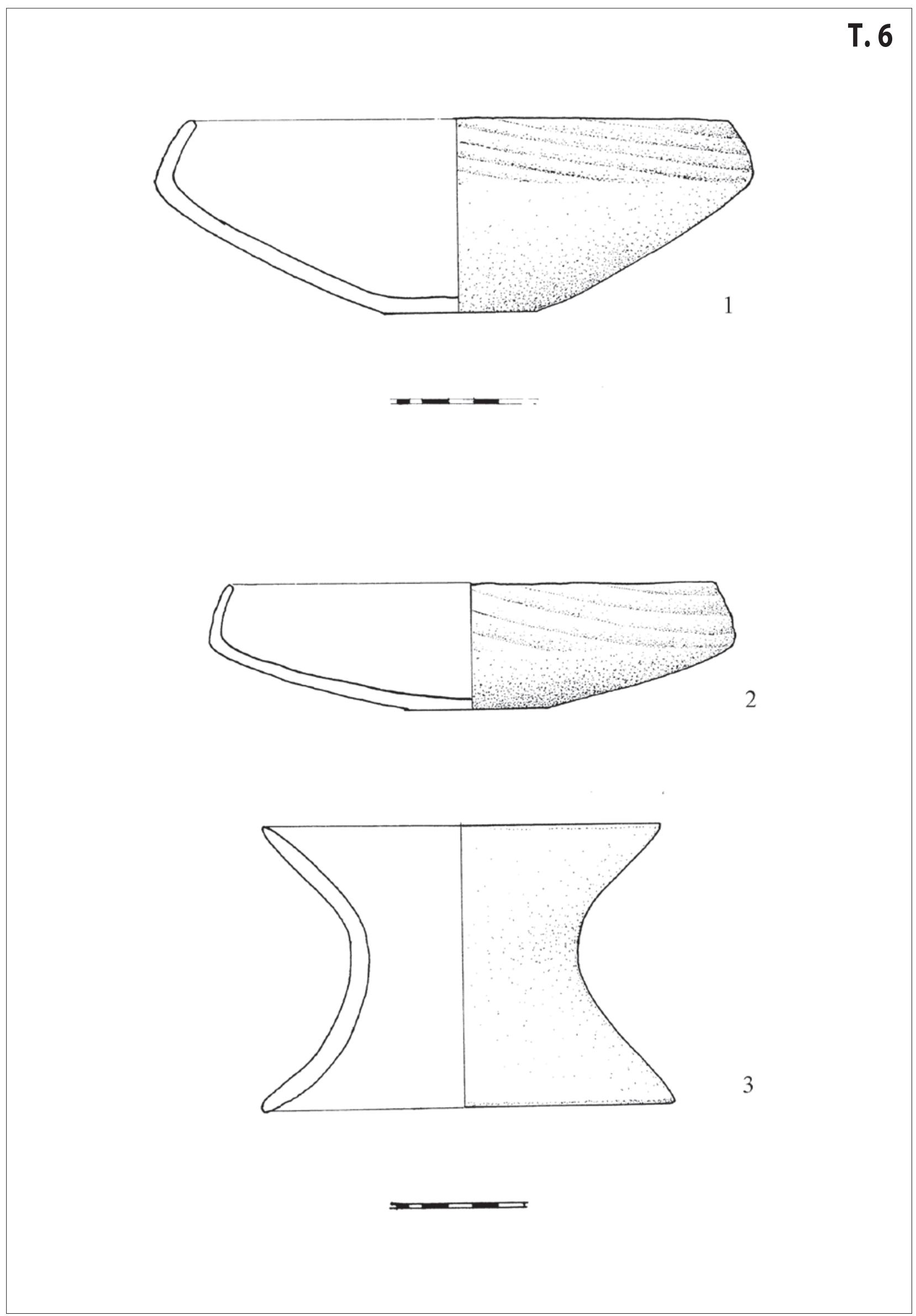

T. 6 Sotin - grob 1 (crtež: M. Galić)

Pl. 6 Sotin - grave 1 (drawning by: M. Galić) 